Prepared for the U.S. Department of Energy under Contract DE-AC05-76RL01830

\title{
Determining Columbia and Snake River Project Tailrace and Forebay Zones of Hydraulic Influence Using MASS2 Modeling
}
CL Rakowski
MC Richmond
JA Serkowski
WA Perkins

2010

Pacific Northwest

NATIONAL LABORATORY

Proudly Operated by Battelle Since 1965 


\title{
DISCLAIMER
}

This report was prepared as an account of work sponsored by an agency of the United States Government. Neither the United States Government nor any agency thereof, nor Battelle Memorial Institute, nor any of their employees, makes any warranty, express or implied, or assumes any legal liability or responsibility for the accuracy, completeness, or usefulness of any information, apparatus, product, or process disclosed, or represents that its use would not infringe privately owned rights. Reference herein to any specific commercial product, process, or service by trade name, trademark, manufacturer, or otherwise does not necessarily constitute or imply its endorsement, recommendation, or favoring by the United States Government or any agency thereof, or Battelle Memorial Institute. The views and opinions of authors expressed herein do not necessarily state or reflect those of the United States Government or any agency thereof.

\author{
PACIFIC NORTHWEST NATIONAL LABORATORY \\ operated by \\ BATTELLE \\ for the \\ UNITED STATES DEPARTMENT OF ENERGY \\ under Contract DE-AC05-76RL01830
}

Printed in the United States of America
Available to DOE and DOE contractors from the Office of Scientific and Technical Information,
P.O. Box 62, Oak Ridge, TN 37831-0062;
ph: (865) 576-8401
fax: $(865) 576-5728$
email: reports@adonis.osti.gov

\footnotetext{
Available to the public from the National Technical Information Service, U.S. Department of Commerce, 5285 Port Royal Rd., Springfield, VA 22161 ph: (800) 553-6847 fax: $(703) 605-6900$ email: orders@ntis.fedworld.gov online ordering: http://www.ntis.gov/ordering.htm
}

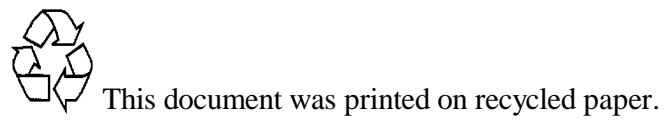




\section{Determining Columbia and Snake River Project Tailrace and Forebay Zones of Hydraulic Influence Using MASS2 Modeling}

CL Rakowski

MC Richmond

JA Serkowski

WA Perkins

2010

Prepared for

U.S. Army Corps of Engineers

Portland District and Walla Walla District

Pacific Northwest National Laboratory

Richland, Washington 99352 



\section{Summary}

Fisheries biology studies are frequently performed at U.S. Army Corps of Engineers (USACE) projects along the Columbia and Snake Rivers, and the results are presented relative to the "forebay" and "tailrace" regions. At this time, each study may use somewhat arbitrary locations (e.g., the Boat Restriction Zone) to define the upstream and downstream limits of the study. The arbitrariness of the delineations could create inconsistencies between projects and make it difficult to draw conclusions involving multiple projects. To overcome this concern, USACE fisheries researchers are interested in establishing a consistent definition of project forebay and tailrace regions for the hydroelectric projects on the lower Columbia and Snake rivers.

The hydraulic extent of a project was defined by USACE CENWP ${ }^{(\mathrm{a})}$ as follows: The river reach directly upstream (forebay) and downstream (tailrace) of a project that is influenced by the normal range of dam operations. Outside this reach, for a particular river discharge, changes in dam operations cannot be detected by hydraulic measurement.

In other words, the hydraulic extent is the zone where the flow direction or velocity can be influened by how the flow is distributed through the powerhouse and spillway bays at a project, i.e., the percent of spill flow, the spill pattern, and the turbines that are operational.

The purpose of this study was to develop and apply a consistent set of criteria for determining the hydraulic extent of each of the projects in the lower Columbia and Snake rivers. This was done in consultation with USACE and regional representatives,

A 2D depth-averaged river model, MASS2, was applied to the Snake and Columbia Rivers. New computational meshes were developed for most reaches, and the underlying bathymetric data were updated to include the most current survey data. These computational meshes were sufficient to resolve each spillway bay and turbine unit at each project, and they extended from the tailrace of one project to the forebay of the downstream project.

MASS2 was run for a range of total river flows and, for each total river flow, a range of project operations at each project. The modeled flow was analyzed to determine the range of velocity magnitude differences and the range of flow direction differences at each location in the computational mesh for each total river flow. Maps of the differences in flow direction and velocity magnitude were created.

After reviewing the preliminary results, USACE fishery biologists requested data analysis to determine the project hydraulic extent based on the following criteria:

- If mean water velocity is less than $4 \mathrm{ft} / \mathrm{s}$, the differences in the magnitude water velocity between operations are not greater than $0.5 \mathrm{ft} / \mathrm{s}$ or the differences in water flow direction (azimuth) are not greater than $10^{\circ}$.

(a) Brad Eppard, USACE, CENWP in "Project Boundaries for Bonneville, The Dalles, and John Day Dams," April 2010. 
- If mean water velocity is $4.0 \mathrm{ft} / \mathrm{s}$ or greater, the project hydraulic extent is determined using the differences in water flow direction (i.e., not greater than $10^{\circ}$ ).

Based on these criteria, and excluding areas with a mean velocity of less than $0.1 \mathrm{ft} / \mathrm{s}$ (within the error of the model), a final set of graphics was developed that included data from all flows and all operations.

Although each hydroelectric project has a different physical setting, there were some common results. The downstream hydraulic extent tended to be greater than the hydraulic extent in the forebay. The hydraulic extent of the projects tended to be larger at the mid-range flows. At higher flows, the channel geometry tends to reduce the impact of project operations. Table 1 summarizes the proposed upstream and downstream distances of the hydraulic extents of each project and its River Mile.

Table 1. Hydraulic Extents Summary

\begin{tabular}{lrrrr}
\hline \multirow{2}{*}{ Project } & \multicolumn{2}{c}{ Forebay } & \multicolumn{2}{c}{ Tailrace } \\
& Distance (ft) & River Mile & Distance (ft) & River Mile \\
\hline Columbia River & & & & \\
\hline Bonneville & 5900 & 147.2 & 11,500 & 143.9 \\
The Dalles & 6300 & 192.9 & 5800 & 190.6 \\
John Day & 2800 & 216.2 & 7600 & 214.2 \\
McNary & 3700 & 292.7 & 7600 & 290.6 \\
\hline Snake River & & & & \\
\hline Ice Harbor & 2200 & 10.3 & 2700 & 9.4 \\
Lower Monumental & 2400 & 42.1 & 6900 & 40.3 \\
Little Goose & 2200 & 70.7 & 5100 & 69.3 \\
Lower Granite & 1100 & 107.5 & 7300 & 105.9 \\
\hline
\end{tabular}




\section{Abbreviations and Acronyms}

$\begin{array}{ll}\text { ABBREV } & \text { DEFINITION } \\ \text { 2D } & \text { two dimensional } \\ \text { 3D } & \text { three dimensional } \\ \text { ADCP } & \text { acoustic Doppler current profiler } \\ \text { BON } & \text { Bonneville Dam } \\ \text { BRZ } & \text { boat restricted zone } \\ \text { CENWP } & \text { U.S. Army Corps of Engineers, Portland District } \\ \text { CENWW } & \text { U.S. Army Corps of Engineers, Walla Walla District } \\ \text { DEM } & \text { digital elevation model } \\ \text { DGAS } & \text { Dissolved Gas Abatement Study } \\ \text { FPP } & \text { Fish Passage Plan } \\ \text { GIS } & \text { Geographic Information System } \\ \text { IHR } & \text { Ice Harbor Dam } \\ \text { JDA } & \text { John Day Dam } \\ \text { kcfs } & \text { Thousand cubic feet per second } \\ \text { LGO } & \text { Little Goose Dam } \\ \text { LGR } & \text { Lower Granite Dam } \\ \text { LMN } & \text { Lower Monumental Dam } \\ \text { MASS2 } & \text { Modular Aquatic Simulation System in Two Dimensions } \\ \text { MCN } & \text { McNary Dam } \\ \text { NAD27 } & \text { North American Datum of 1927 } \\ \text { NAD83 } & \text { North American Datum of 1983 } \\ \text { NAVD29 } & \text { North American Vertical Datum of 1929 } \\ \text { NOAA } & \text { National Oceanic and Atmospheric Administration } \\ \text { PNNL } & \text { Pacific Northwest National Laboratory } \\ \text { TDA } & \text { The Dalles Dam } \\ \text { USACE } & \text { U.S. Army Corps of Engineers } \\ \text { USGS } & \text { U.S. Geological Survey } \\ \text { USFWS } & \text { U.S. Fish and Wildlife Service } \\ \text { vmag } & \text { Velocity magnitude } \\ & \end{array}$





\section{Acknowledgments}

Financial support for this study was provided by the U.S. Army Corps of Engineers (USACE) under MIPR W66QKZ93383147. The authors would like to thank Laurie Ebner, Brad Eppard (USACE, Portland District) and Ryan Laughery and Ann Setter (USACE, Walla Walla District) for the discussions, support, and insight that improved this study. Lyle Hibler provided comments that improved this report. 



\section{Contents}

Summary ......................................... ii

Abbreviations and Acronyms . . . . . . . . . . . . . . . . . v v

Acknowledgments ..................................... vii

1.0 Introduction . . . . . . . . . . . . . . . . . . . . . 1.1

2.0 Methods . . . . . . . . . . . . . . . . . . . . . . . 2.1

2.1 MASS2 Model-General Description . . . . . . . . . . . . . . . 2.1

2.2 Bathymetry and Shorelines . . . . . . . . . . . . . . . . . 2.1

2.3 Computational Meshes . . . . . . . . . . . . . . . . . . 2.12

2.3 .1 Bonneville Tailrace and Tidal Reach . . . . . . . . . . . . . . 2.12

2.3 .2 Bonneville Pool . . . . . . . . . . . . . . . . 2.12

2.3 .3 The Dalles Pool . . . . . . . . . . . . . . . . . . . 2.12

2.3 .4 John Day Pool $\ldots \ldots \ldots \ldots$. . . . . . . . . . . . . . . . . . . . . . . . . .

2.3 .5 McNary Pool up to Ice Harbor Dam . . . . . . . . . . . . . . . 2.15

2.3 .6 Lower Monumental Pool . . . . . . . . . . . . . . . . . . . . 2.15

2.4 Model Configuration and Scenarios . . . . . . . . . . . . . . 2.22

2.4 .1 General MASS2 Configuration . . . . . . . . . . . . 2.22

2.4 .2 Bonneville Project . . . . . . . . . . . . . . 2.23

2.4 .3 The Dalles Project . . . . . . . . . . . . . . . 2.25

2.4 .4 John Day Project $\ldots \ldots \ldots \ldots \ldots \ldots$. . . . . . . . . . . . . . . . . . . . . .

2.4 .5 McNary Project . . . . . . . . . . . . . . . . . 2.29

2.4 .6 Ice Harbor Project $\ldots \ldots \ldots$. . . . . . . . . . . . . . 2.31

2.4 .7 Lower Monumental Project . . . . . . . . . . . . . . . . . 2.33 
$2.4 .8 \quad$ Little Goose Project $\ldots \ldots \ldots \ldots$

$2.4 .9 \quad$ Lower Granite Project $\ldots \ldots \ldots \ldots$

2.5 Analysis of Simulation Data $\ldots \ldots \ldots \ldots \ldots \ldots$

3.0 Results and Discussion $\ldots \ldots \ldots \ldots$

3.1 Bonneville Project $\ldots \ldots \ldots \ldots \ldots . \ldots \ldots \ldots$

3.2 The Dalles Project $\ldots \ldots \ldots \ldots \ldots$

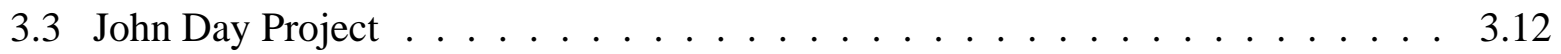

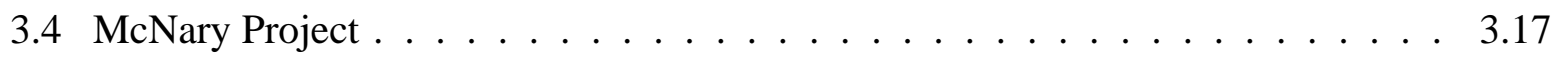

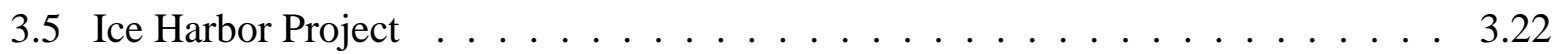

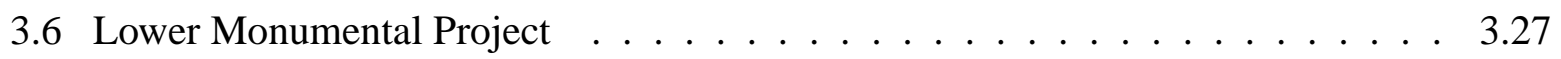

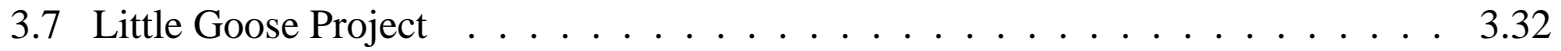

3.8 Lower Granite Project $\ldots \ldots \ldots$

3.9 Hydraulic Extents . . . . . . . . . . . . . . . . . . . . . 3.42

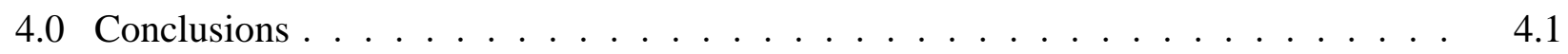

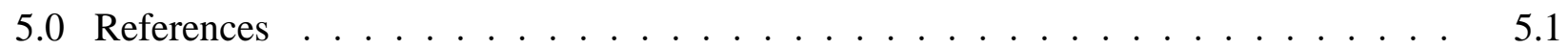




\section{Figures}

$1.1 \quad$ Location of the Walla Walla District Projects and Portland District Projects . . . . . 1.2

$2.1 \quad$ Bathymetry and Computational Mesh near the Bonneville Project . . . . . . . . . 2.13

$2.2 \quad$ Bathymetry and Computational Mesh near The Dalles Project . . . . . . . . . . . . 2.14

$2.3 \quad$ Bathymetry and Computational Mesh near the John Day Project. . . . . . . . . . . 2.16

$2.4 \quad$ Bathymetry and Computational Mesh near the McNary Project . . . . . . . . . . 2.17

$2.5 \quad$ Bathymetry and Computational Mesh near the Ice Harbor Project . . . . . . . . . . 2.18

$2.6 \quad$ Bathymetry and Computational Mesh near the Lower Monumental Project . . . . . 2.19

$2.7 \quad$ Bathymetry and Computational Mesh near the Little Goose Project . . . . . . . . . 2.20

$2.8 \quad$ Bathymetry and Computational Mesh near the Lower Granite Project . . . . . . . . 2.21

$3.1 \quad$ Bonneville Dam for $150 \mathrm{kcfs} \ldots \ldots \ldots \ldots$

$3.2 \quad$ Bonneville Dam for $250 \mathrm{kcfs} \ldots \ldots \ldots \ldots$

3.3 Bonneville Dam for $350 \mathrm{kcfs} \ldots \ldots \ldots \ldots$

$3.4 \quad$ Bonneville Dam for $450 \mathrm{kcfs} \ldots \ldots \ldots$

3.5 The Dalles Project for $150 \mathrm{kcfs} \ldots \ldots \ldots \ldots \ldots$

3.6 The Dalles Project for $250 \mathrm{kcfs} \ldots \ldots \ldots \ldots$

3.7 The Dalles Project for $270 \mathrm{kcfs} \ldots \ldots \ldots \ldots$

3.8 The Dalles Project for $450 \mathrm{kcfs} \ldots \ldots \ldots \ldots \ldots \ldots$

$3.9 \quad$ John Day Project for $150 \mathrm{kcfs} \ldots \ldots \ldots \ldots . \ldots \ldots$

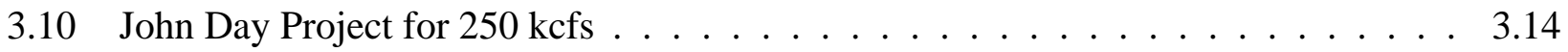

3.11 John Day Project for $320 \mathrm{kcfs}$. . . . . . . . . . . . . . . . 3.15

3.12 John Day Project for $450 \mathrm{kcfs}$. . . . . . . . . . . . . . . . 3.16

3.13 McNary Project for $100 \mathrm{kcfs} \ldots \ldots \ldots \ldots . \ldots \ldots$ 
3.14 McNary Project for $150 \mathrm{kcfs} \quad \ldots \ldots \ldots \ldots . \ldots \ldots$

3.15 McNary Project for $250 \mathrm{kcfs} \ldots \ldots \ldots \ldots \ldots \ldots . \ldots \ldots$

3.16 McNary Project for $350 \mathrm{kcfs} \ldots \ldots \ldots \ldots \ldots . \ldots \ldots . \ldots \ldots$

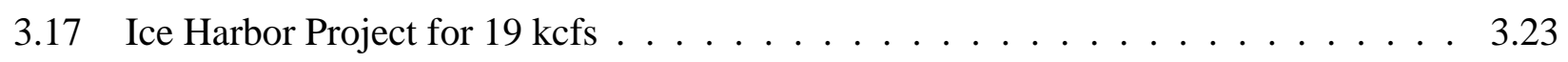

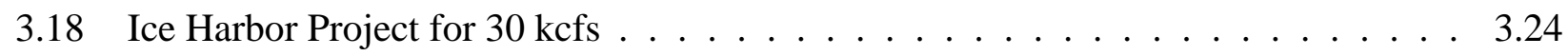

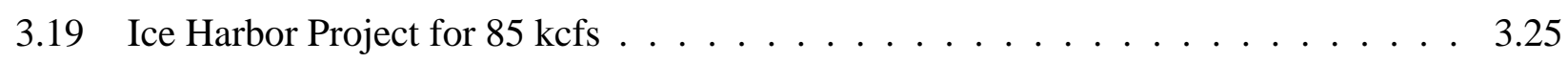

$3.20 \quad$ Ice Harbor Project for $120 \mathrm{kcfs} \quad \ldots \ldots \ldots . \ldots \ldots \ldots$

$3.21 \quad$ Lower Monumental Project for $19 \mathrm{kcfs}$. . . . . . . . . . . . . . . . . . 3.28

3.22 Lower Monumental Project for $30 \mathrm{kcfs}$. . . . . . . . . . . . . . . . . . . 3.29

3.23 Lower Monumental Project for $85 \mathrm{kcfs}$. . . . . . . . . . . . . . . . 3.30

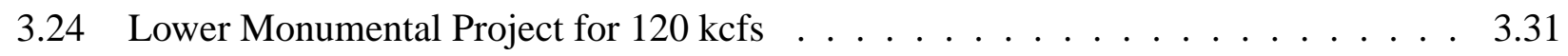

3.25 Little Goose Project for $19 \mathrm{kcfs}$. . . . . . . . . . . . . . . . . 3.33

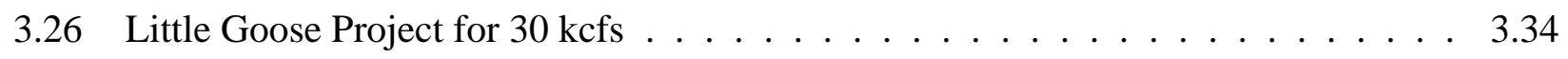

3.27 Little Goose Project for $85 \mathrm{kcfs} \ldots \ldots \ldots \ldots \ldots . \ldots \ldots . \ldots \ldots$

3.28 Little Goose Project for $120 \mathrm{kcfs} \quad \ldots \ldots \ldots \ldots . \ldots \ldots . . \ldots \ldots$

3.29 Lower Granite Project for $19 \mathrm{kcfs} \ldots \ldots \ldots . \ldots \ldots . \ldots \ldots$

$3.30 \quad$ Lower Granite Project for $30 \mathrm{kcfs}$. . . . . . . . . . . . . . . . . . . . . . 3.39

$3.31 \quad$ Lower Granite Project for $85 \mathrm{kcfs}$. . . . . . . . . . . . . . . . . . 3.40

3.32 Lower Granite Project for $120 \mathrm{kcfs} \quad \ldots \ldots \ldots . \ldots \ldots . . \ldots \ldots$

3.33 Bonneville Proposed Hydraulic Extents . . . . . . . . . . . . . . . . . . . 3.43

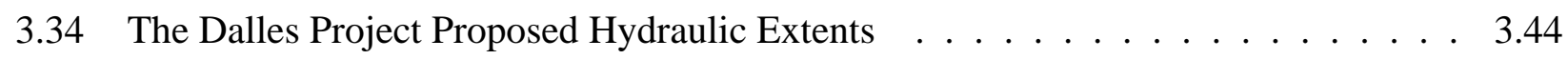

3.35 John Day Project Proposed Hydraulic Extents $\ldots \ldots \ldots . . \ldots \ldots$

3.36 McNary Project Proposed Hydraulic Extents $\ldots \ldots \ldots . . \ldots \ldots$ 
3.37 Ice Harbor Project Proposed Hydraulic Extents . . . . . . . . . . . . . . . . . . . . 3.47

$3.38 \quad$ Lower Monumental Project Proposed Hydraulic Extents . . . . . . . . . . . . . . . 3.48

3.39 Little Goose Project Proposed Hydraulic Extents . . . . . . . . . . . . . . . . . . . 3.49

$3.40 \quad$ Lower Granite Project Proposed Hydraulic Extents . . . . . . . . . . . . . . . . . . 3.50 


\section{Tables}

1 Hydraulic Extents Summary . . . . . . . . . . . . . . . . . iv

$2.1 \quad$ Datasets Used to Create Bathymetric Surface Downstream of Bonneville (BON)

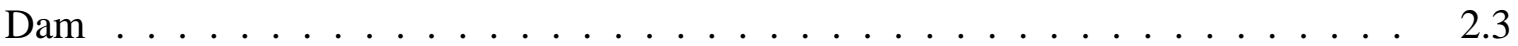

2.2 Datasets Used to Create Bathymetric Surface for the BON Pool and The Dalles Dam

(TDA) Tailrace . . . . . . . . . . . . . . . . . . . . . . . 2.4

2.3 Datasets Used to Create Bathymetric Surface for the TDA Pool and the John Day

Dam (JDA) Tailrace . . . . . . . . . . . . . . . . . . 2.5

2.4 Datasets Used to Create Bathymetric Surface for JDA Pool and McNary Dam (MCN)

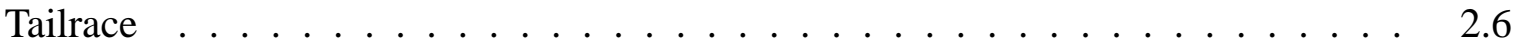

2.5 Datasets Used to Create Bathymetric Surface for the MCN Pool and Ice Harbor

Dam (IHR) Tailrace . . . . . . . . . . . . . . . . . . . 2.7

2.6 Datasets Used to Create Bathymetric Surface for the IHR Pool and Lower Monumental Dam $(\mathrm{LMN})$ Tailrace. $\ldots \ldots \ldots \ldots$. . . . . . . . . . . . . . . . . . . . .

2.7 Datasets Used to Create Bathymetric Surface for the LMN and Little Goose Dam (LGO) Tailrace $\ldots \ldots \ldots \ldots \ldots \ldots \ldots$

2.8 Datasets Used to Create Bathymetric Surface for the LGO Pool and Lower Granite (LGR) Tailrace . . . . . . . . . . . . . . . . . . 2.10

$2.9 \quad$ Datasets Used to Create Bathymetric Surface for the LGR Pool. . . . . . . . . . . . 2.11

2.10 Bonneville Scenarios $\ldots \ldots \ldots \ldots \ldots \ldots$

2.11 Bonneville Powerhouse 1 and Powerhouse 2 Operations . . . . . . . . . . . . . 2.24

2.12 The Dalles Scenarios . . . . . . . . . . . . . . . . . . . . 2.25

2.13 The Dalles Operations $\ldots \ldots \ldots \ldots \ldots$

2.14 John Day Project Scenarios . . . . . . . . . . . . . . . . . . 2.27

2.15 John Day Operations $\ldots \ldots \ldots \ldots \ldots \ldots$

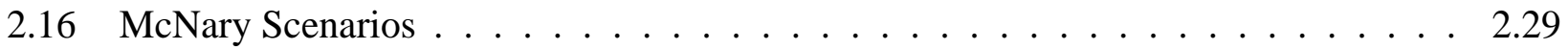

2.17 McNary Operations . . . . . . . . . . . . . . . . 2.30 
2.18 Ice Harbor Scenarios $\ldots \ldots \ldots \ldots \ldots \ldots \ldots$

2.19 Ice Harbor Operations $\ldots \ldots \ldots \ldots$. . . . . . . . . . . . . . . . 2.32

2.20 Lower Monumental Scenarios . . . . . . . . . . . . . . . . . . . 2.33

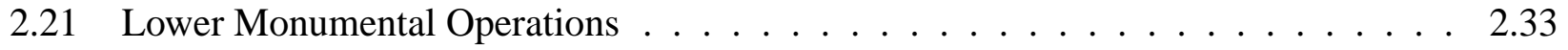

2.22 Little Goose Scenarios . . . . . . . . . . . . . . . . . . . . . . . . . 2.34

2.23 Little Goose Operations $\ldots \ldots \ldots$. . . . . . . . . . . . . . . . 2.34

2.24 Lower Granite Scenarios $\ldots \ldots \ldots$. . . . . . . . . . . . . . . 2.35

2.25 Lower Granite Operations $\ldots \ldots \ldots$. . . . . . . . . . . . . . . . . 2.35

$3.1 \quad$ Hydraulic Extents Summary . . . . . . . . . . . . . . . . . . . . . . . . . 3.42 



\subsection{Introduction}

Although fisheries biology studies are frequently performed at U.S. Army Corps of Engineers (USACE) projects along the Columbia and Snake Rivers, currently there is no consistent definition of the "forebay" and "tailrace" regions for these studies. At this time, each study may use somewhat arbitrary lines (e.g., the Boat Restriction Zone) to define the upstream and downstream limits of the study, which may be significantly different at each project. Fisheries researchers are interested in establishing a consistent definition of project forebay and tailrace regions that define the hydraulic extent of a project. The hydraulic extent was defined by USACE (Brad Eppard, USACE Portland District (CENWP)) as follows: The river reach directly upstream (forebay) and downstream (tailrace) of a project that is influenced by the normal range of dam operations. Outside this reach, for a particular river discharge, changes in dam operations cannot be detected by hydraulic measurement.

The purpose of this project is to develop standard procedures to determine the operationally influenced extent of the forebay and tailrace regions in accordance with the following definitions:

- Forebay: The segment of river immediately upstream of a dam where operations at the dam are the primary contributing factor to velocity and direction of water flow. The upstream boundary defines the upstream limit where operational changes affect water velocity magnitude and direction.

- Tailrace: The segment of river immediately downstream of a dam where operations at the dam are the primary contributing factor to velocity and direction of water flow. The downstream boundary defines the downstream limit where operational changes affect water velocity magnitude and direction.

In 2008, Pacific Northwest National Laboratory (PNNL) used the John Day project as the test case to establish the modeling methodology and criteria to define areas affected by project operations at John Day in both the forebay and tailrace (Rakowski et al.2008a). It was assumed that the forebay and tailrace definition could be adequately defined using a two-dimensional (2D) depth-averaged modeling approach instead of a true three-dimensional (3D) modeling effort. Using the 2D MASS2 model (Perkins and Richmond 2004b) saves significant computational time, especially given the large number of operational scenarios that must be simulated. Assessment criteria included the selection of river flows and hydraulic comparisons (velocity magnitude, direction, and/or tolerances).

In this study, the methodology and criteria established in Rakowski et al. (2008a) were applied to other projects on the Columbia and Snake Rivers (Figure 1.1) to define their respective forebay and tailrace regions for CENWP and USACE Walla Walla District (CENWW). Based on input from regional fisheries biologists, some of the criteria were modified for this work. 


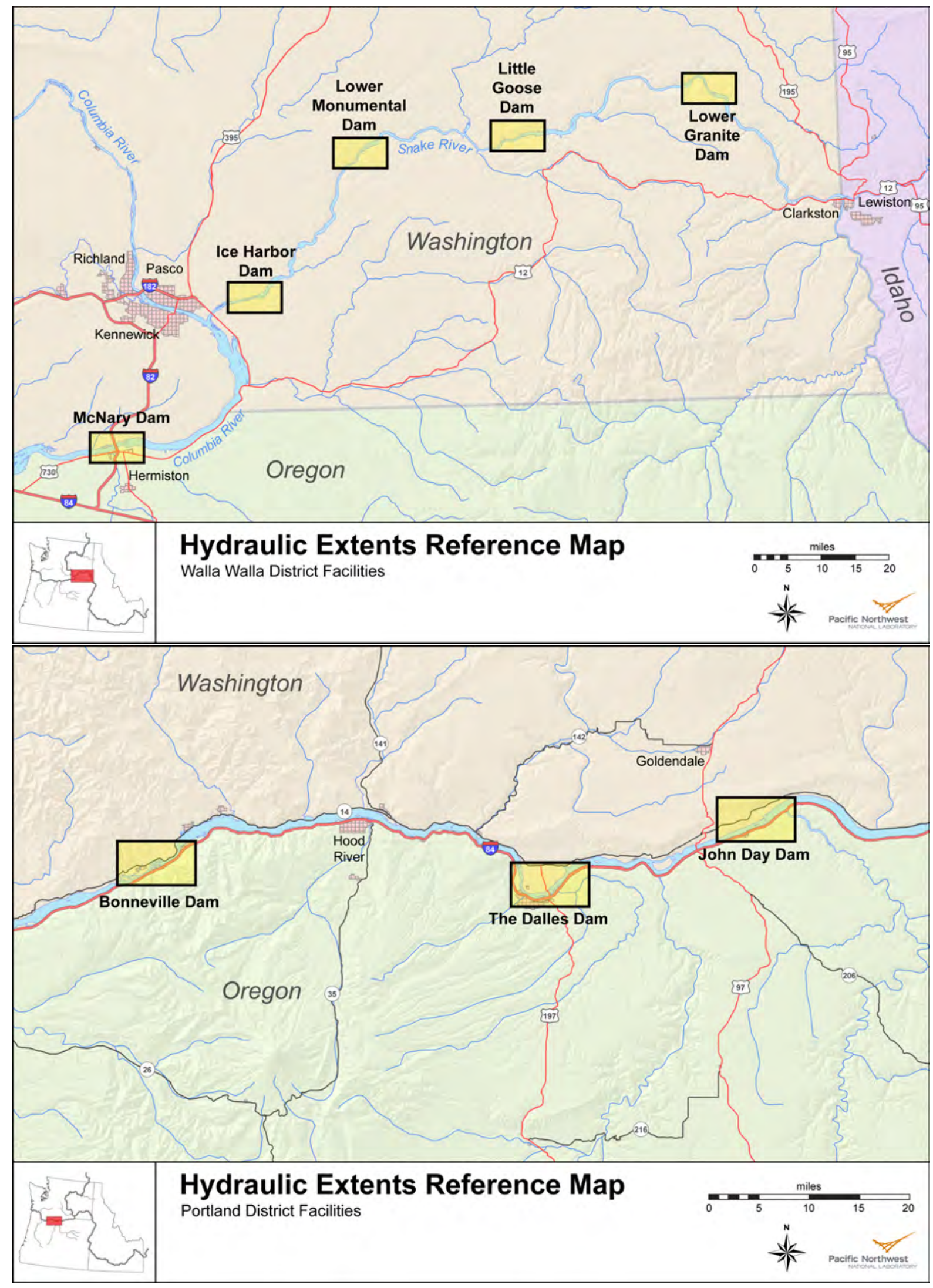

Figure 1.1. Location of the Walla Walla District Projects (top) and Portland District Projects (bottom) 


\subsection{Methods}

This work used the approach described by Rakowski et al.(2008a). However, rather than relying on existing computational meshes, the meshes used in the present study had increased resolution near the hydro projects. The bathymetry was updated to incorporate the most current survey data available.

\subsection{MASS2 Model-General Description}

The Modular Aquatic Simulation System in 2 Dimensions (MASS2) was developed at PNNL (Perkins and Richmond 2004a c) and has been successfully applied to a variety of river and estuarine flows (Richmond et al. 1999a, Rakowski and Richmond 2001, 2003, Rakowski et al. 2008b), water quality (Richmond et al. 1999b c, 2000, Kincaid et al. 2001) and aquatic habitat (McMichael et al. 2003, Perkins et al. 2004, Hanrahan et al. 2007) problems.

MASS2 is formulated using the general finite-volume principles described by Patankar (1980). The model uses a structured multi-block scheme using a curvilinear computational mesh. Spasojevic and Holly (1990) give an example of a 2D model of this type. The momentum and mass conservation equations are coupled with a variation of the Patankar (1980) SIMPLE algorithm extended to shallow-water flows by Zhou (1995). In MASS2, Zhou's method has been applied to orthogonal curvilinear coordinates. In this method, the continuity equation is discretized and solved for a depth correction in lieu of the pressure correction in the original SIMPLE algorithm. The solution to the depth correction equation is used to correct the estimated velocity from the solution of the momentum equations. A portion of the depth correction is used to adjust depth. An in-depth description of the underlying theory for MASS2 is in Perkins and Richmond (2004a).

MASS2 is a depth-averaged river model. Although it works well and matches validation data in the river, the results in areas with highly 3D flows should be used with caution. The meshes of this study were designed for testing the upstream and downstream extents of impacts of project flow distributions rather than the details of flow very near the projects.

\subsection{Bathymetry and Shorelines}

Bathymetric surfaces were created with point and contour elevation data from a variety of sources. Datasets consisted primarily of point soundings from single- and multi-beam acoustic surveys provided by USACE. Where such surveys were unavailable, National Oceanic and Atmospheric Administration (NOAA) navigation charts filled in the gaps. The channel shorelines were manually digitized from high-resolution $(0.5 \mathrm{~m})$ aerial photography obtained from the U.S. Geological Survey (USGS) seamless server (http://seamless.usgs.gov), and assigned an elevation appropriate for the date of the imagery. That elevation was determined using the date of the photo, and then the elevation was estimated from the average of the DART forebay elevations measured during the month when the photo was taken. Typically, the elevations during July 2006 (when the photos were taken) fluctuated no more than about $1 \mathrm{ft}$. Thirty-meter digital elevation model (DEM) points, also from the USGS, provided near-shore topography data to produce a smoother transition between the shoreline and bathymetric datasets. 
The elevation datasets were imported into ArcGIS ${ }^{T M}$ version 9.3.1 (ESRI, Inc.), a geographic information system (GIS), for storage, display, and processing. All datasets were projected into Washington State Plane South coordinates (in meters) using the North American Datum of 1983 (NAD83). Elevation data were generally received in the North American Vertical Datum of 1929 (NAVD29) and this was established as the standard. The point positions and elevations were examined for anomalies, and problem data were rejected. Where domains overlapped, both datasets were generally used, unless one of the datasets was considerably less reliable than the other, in which case it was excluded. The shoreline dataset defined the boundary between the topographic (DEM) and bathymetric data, and bathymetric points residing on the upland side of the shoreline were rejected.

Each bathymetric surface was produced with a script run in ArcGIS. The script gathered the appropriate datasets for the reach, interpolated the elevations onto a uniform raster grid, and projected the result into Oregon State Plane North coordinates (in feet) using the North American Datum of 1927 (NAD27). The raster grid cell size was set to $10 \mathrm{~m}$, which is somewhat smaller than the smallest hydrodynamic model grid cell size.

Tables 2.1 to 2.9 summarize the source datasets used to create each of the bathymetric surfaces. Figures 2.1 to 2.8 show the bathymetric surfaces near each project. Note that in these figures, the overlying mesh is the MASS2 mesh, not the bathymetric surface mesh, and the contour intervals are different for each mesh. 


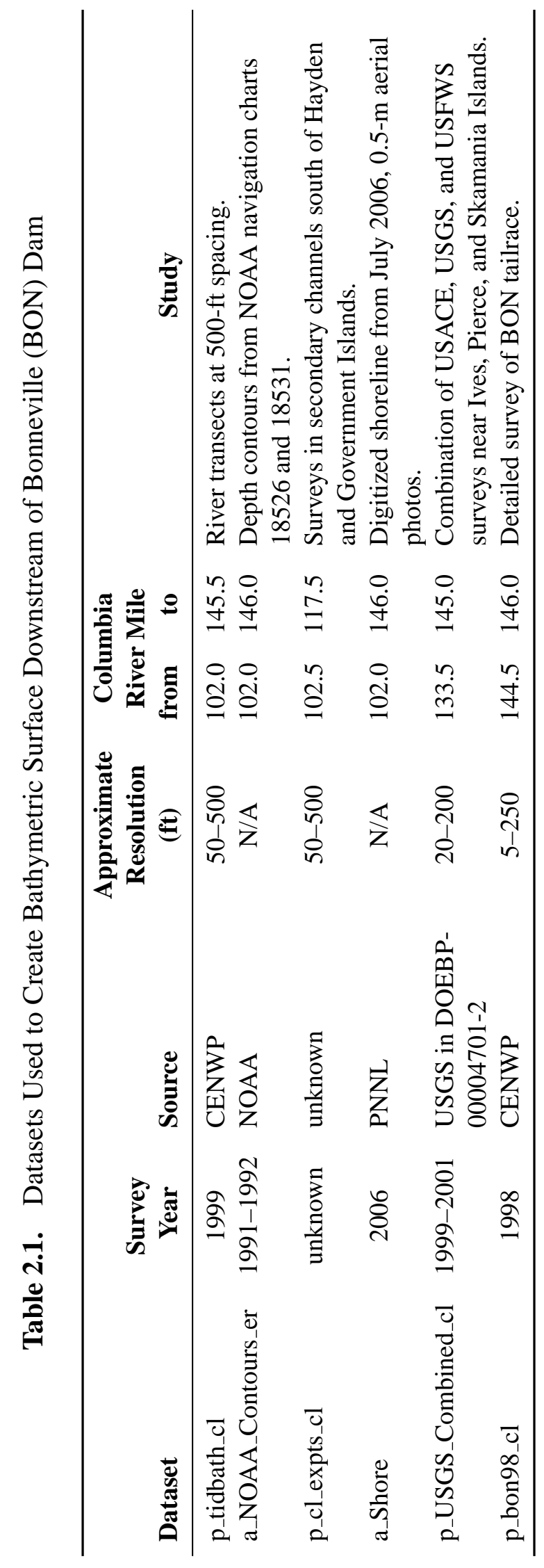




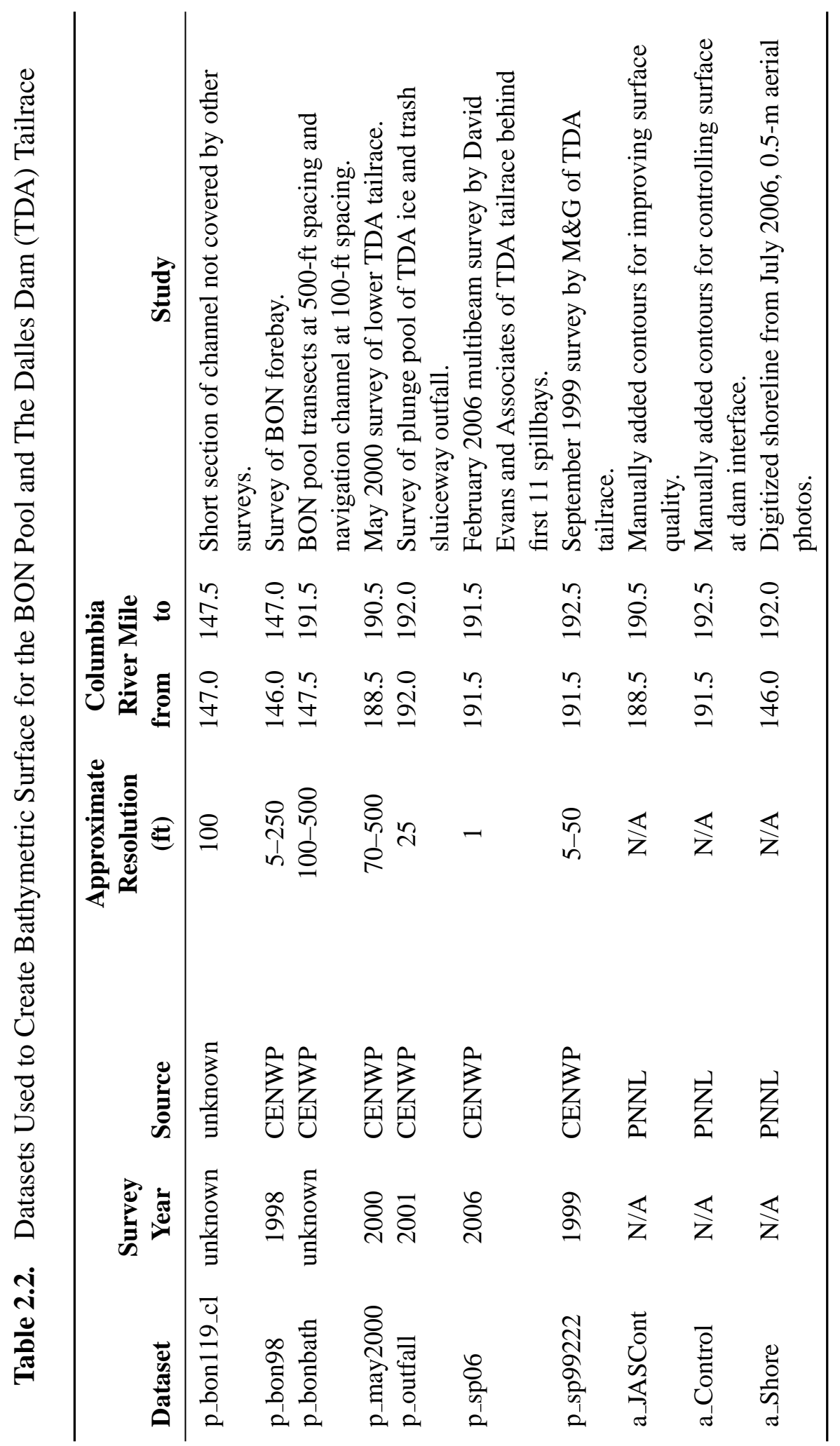




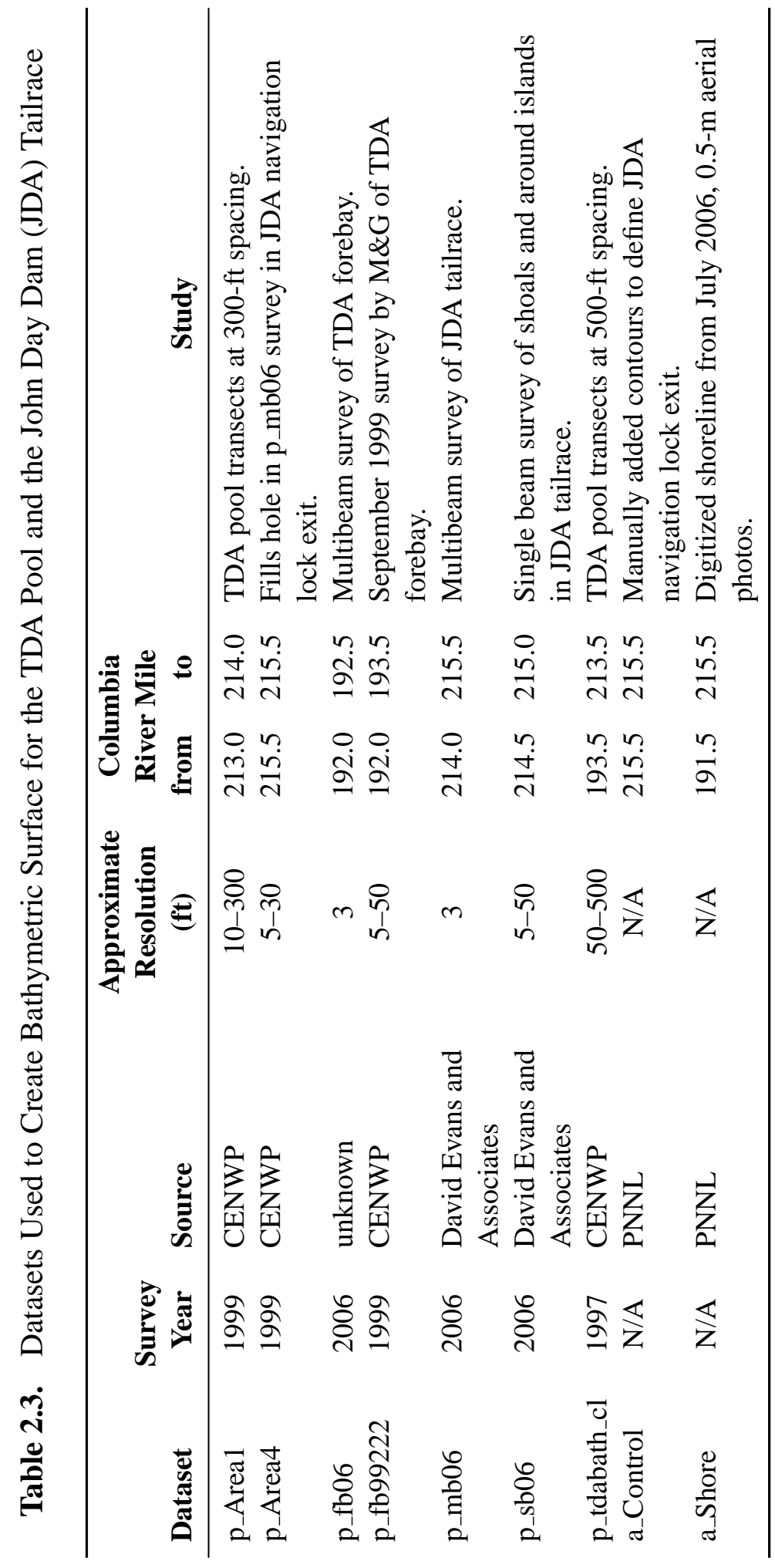




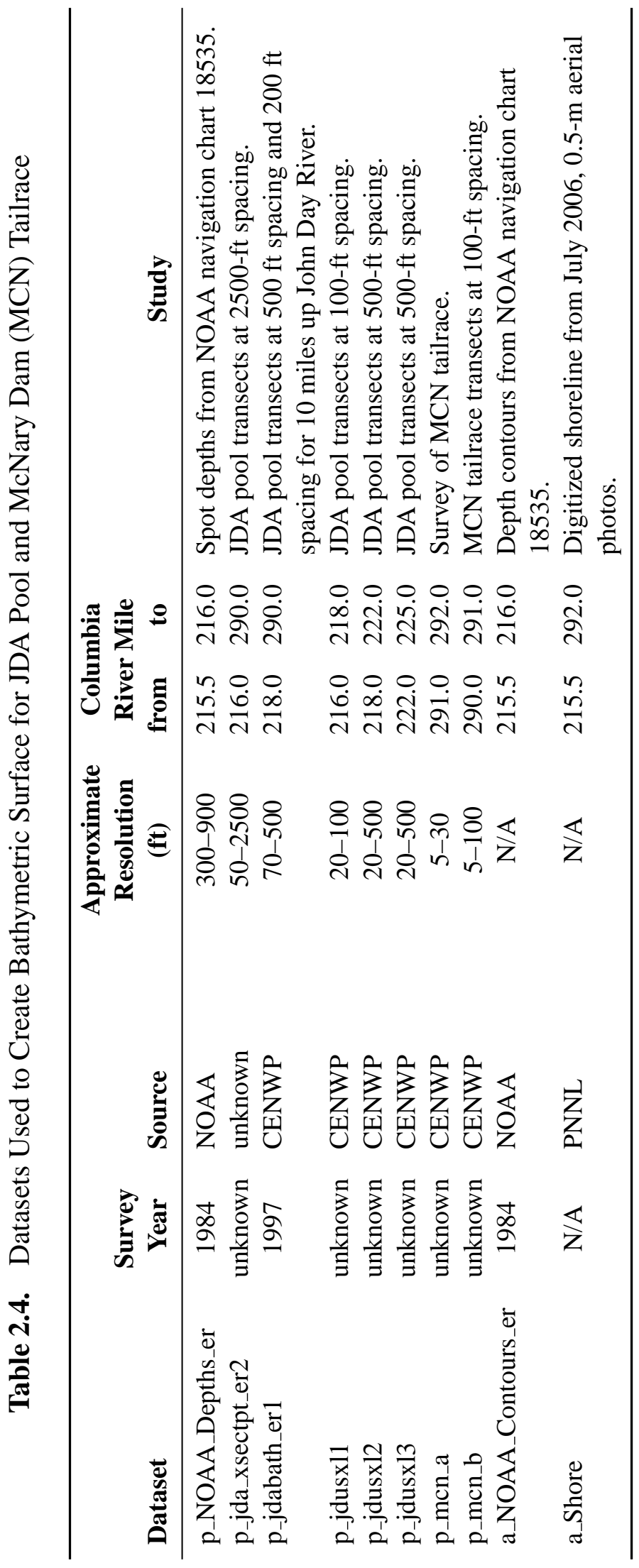




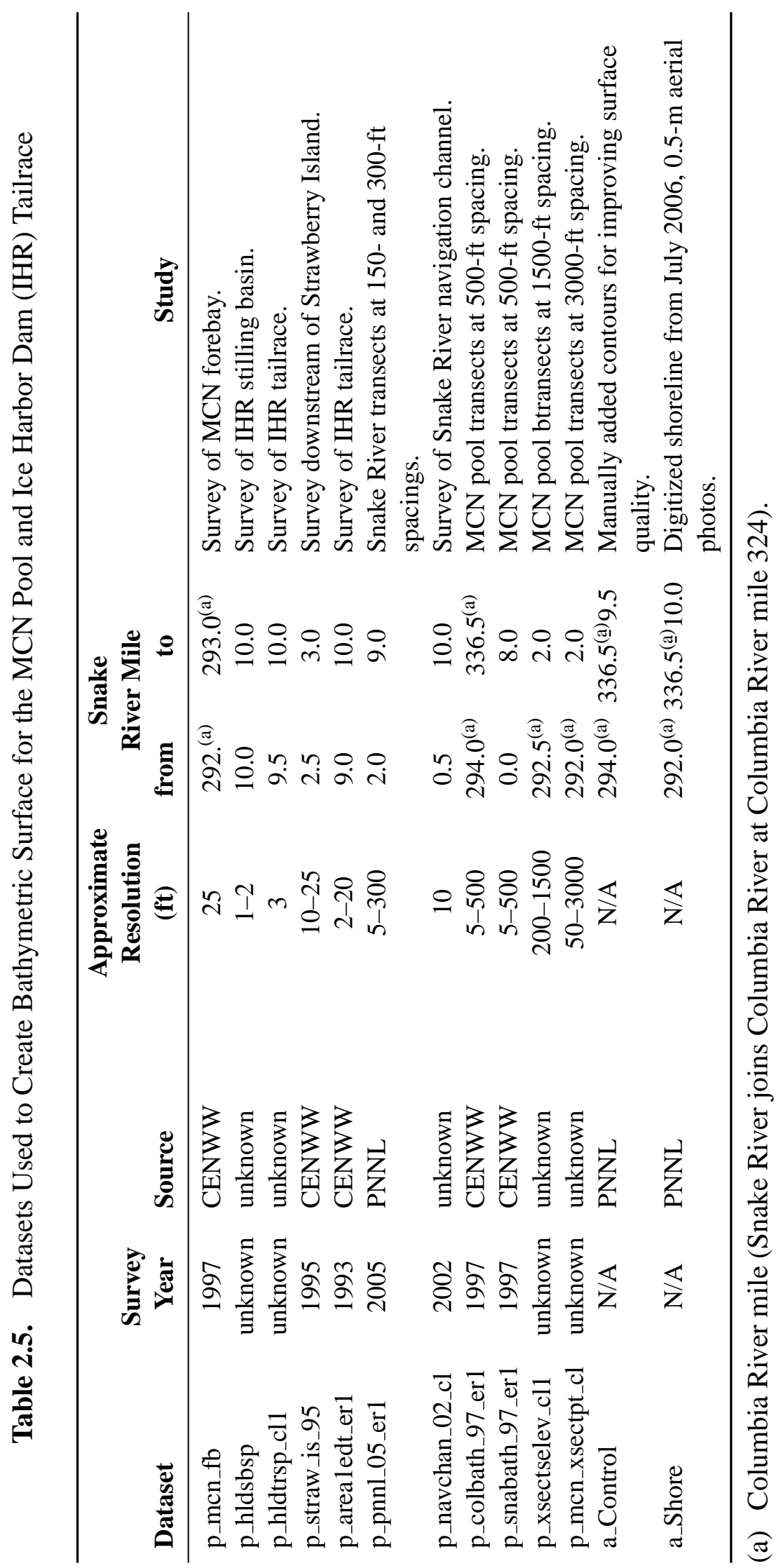




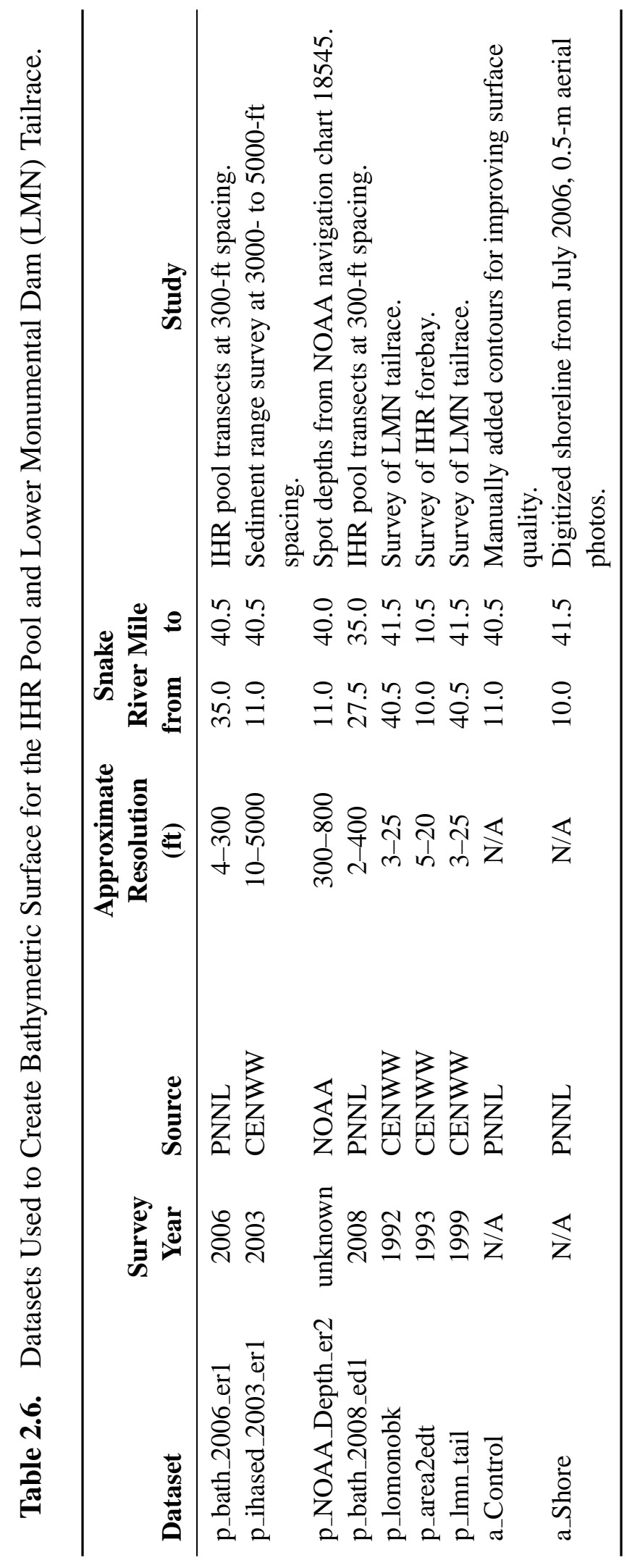




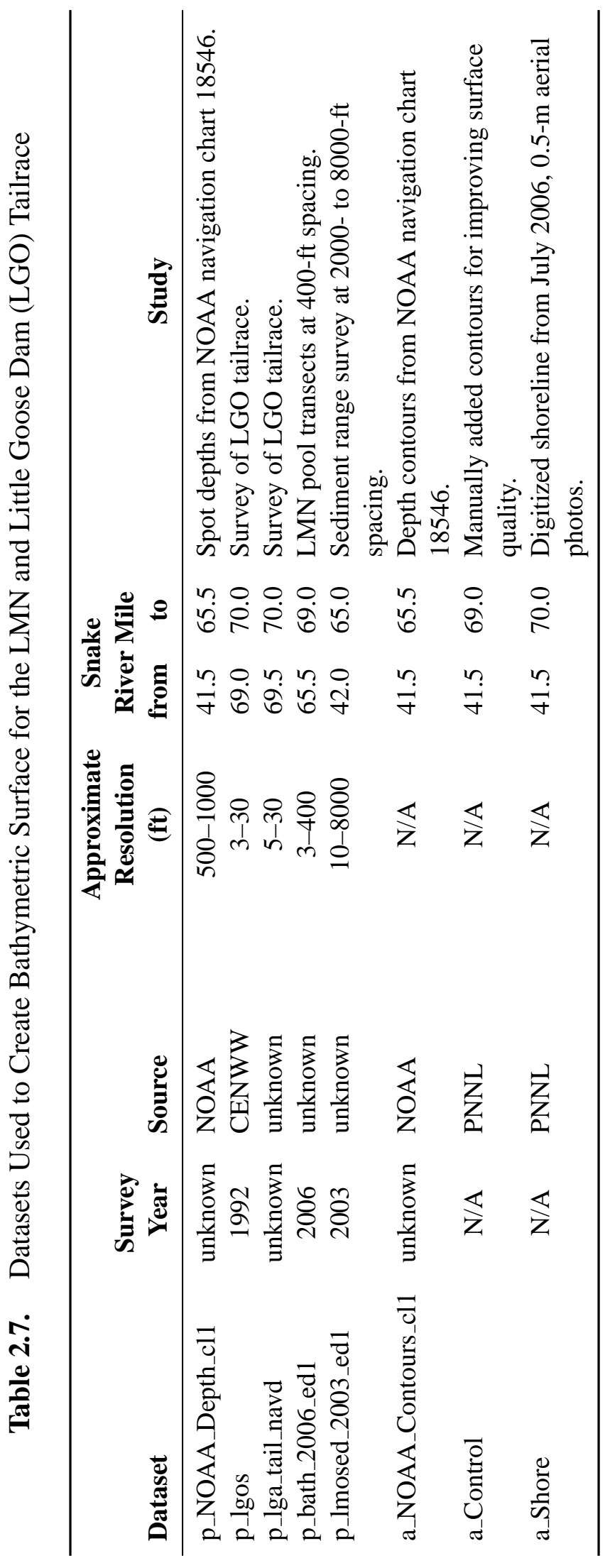




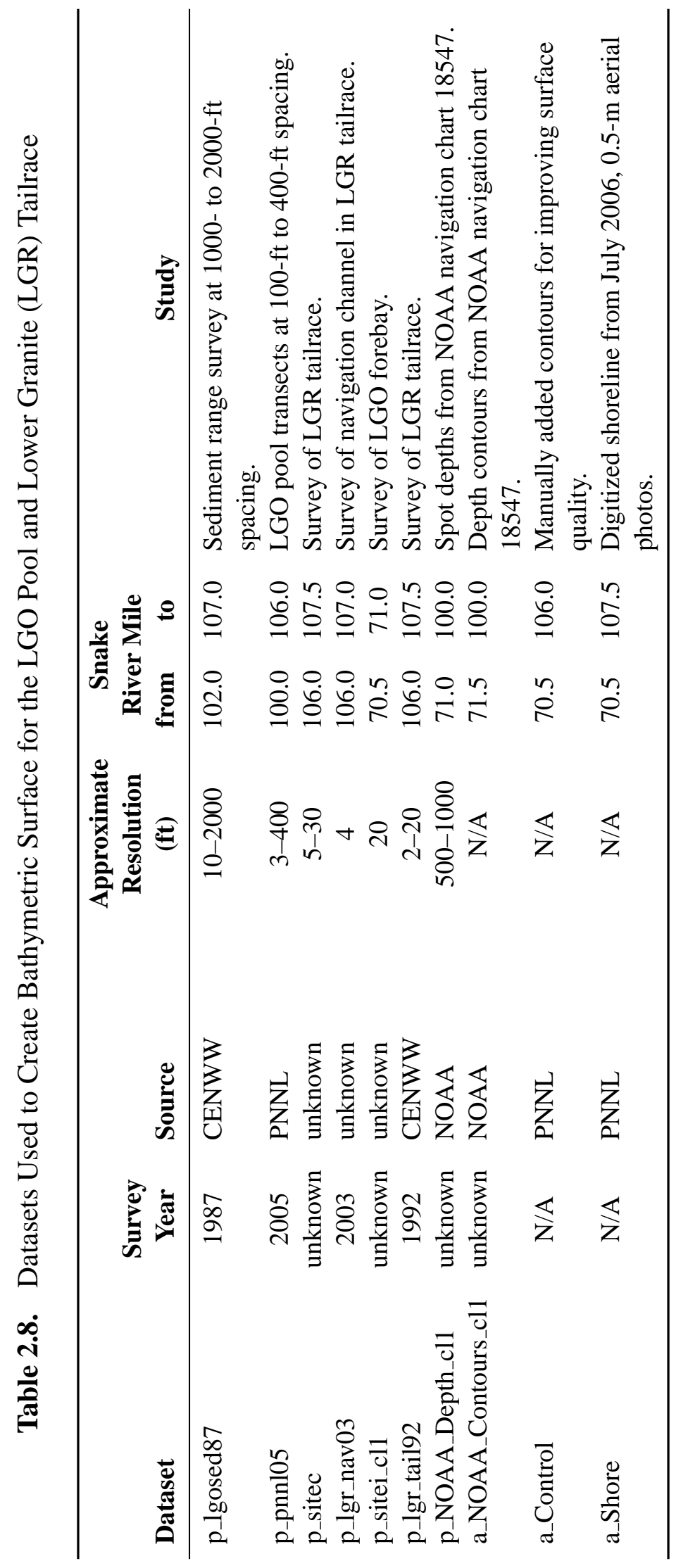




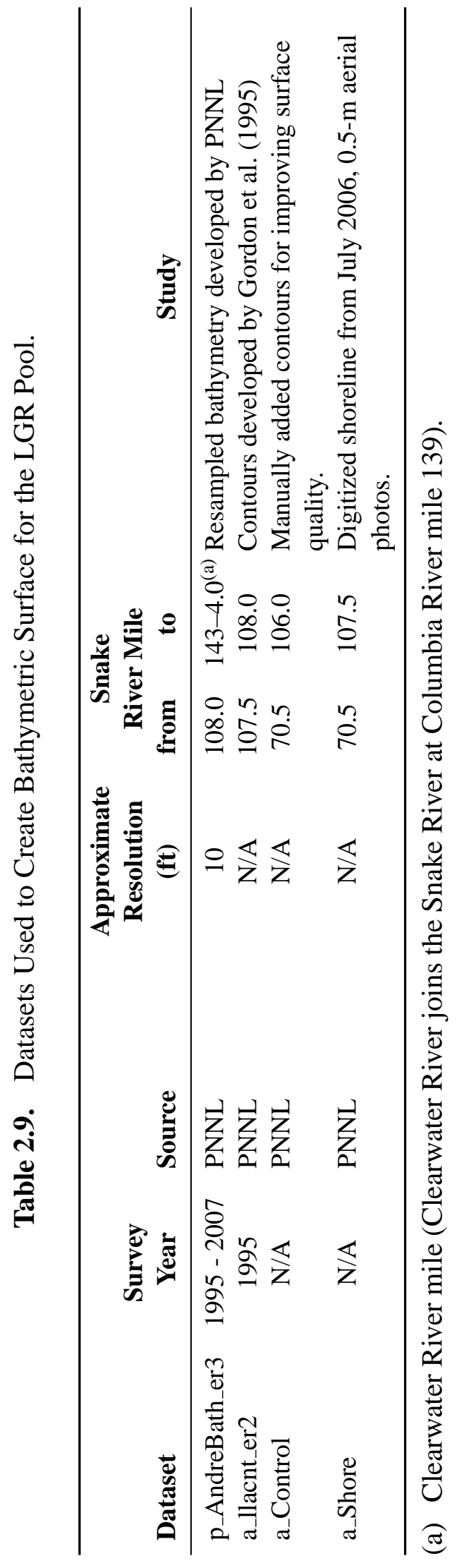




\subsection{Computational Meshes}

All meshes were created in Gridgen ${ }^{T M}$ (Pointwise, Inc 2003), and the extents were based on the shorelines discussed in Section 2.2. For some sections of the river far from the projects, shorelines from the Dissolved Gas Abatement Study (DGAS, Richmond et al.|2000) were used for areas for which no new bathymetry data were available. The areas of interest were near the projects; hence, the mesh resolution in these areas is much finer. Minimum cross-stream resolution included at least one cell per inflow/outflow location, i.e., at least one cell for each spill bay and turbine unit. Areas of increased cross-stream resolution were created for areas larger than the expected hydraulic extents.

The new meshes take advantage of the wetting and drying capabilities of the MASS2 (Perkins and Richmond 2004b) model. Multiple mesh blocks were used around some island features, although the shorelines were simplified and included some upland and island areas to improve mesh orthogonality. The wetting and drying feature of MASS2 creates "shorelines" in appropriate locations, thus accommodating changing water surface elevations.

\subsubsection{Bonneville Tailrace and Tidal Reach}

The tidal reach starts at Bonneville and has its downstream extent at Portland, OR, just upstream of the Willamette River confluence. The cross-stream resolution from the Ives Island complex is about double that found in the DGAS work (Figure 2.1). The purple lines in the bathymetry figures delineate the boat restriction zone (BRZ). The river through and to the north of the Ives Island complex was not included.

\subsubsection{Bonneville Pool}

The Bonneville Pool is from The Dalles to Bonneville Dam. At Bonneville (Figure 2.1), there are two cells per bay for the powerhouses, one per bay at the spillway. The increased crossstream resolution extends from Cascade Locks down to the Bonneville Project. At TDA, the increased cross-stream resolution extends from the project to approximately 3.75 miles downstream. There are two cells per spill bay; however, the powerhouse is not resolved bay-bybay. The powerhouse flow is specified as a single total value and the inflow boundary is located upstream of the flow constriction between the powerhouse and the spillway tailrace.

Below the TDA spillway (Figure 2.2), the bridge islands were included in the mesh to allow for large variations in water surface elevation. The new TDA spillwall was included in the mesh, although the navigation lock was not.

\subsubsection{The Dalles Pool}

In the TDA forebay (Figure 2.2), the spillbays had one cell per bay, the location of the navigation lock wall was included, and the powerhouse had two cells per turbine unit. The area of increased cross-stream resolution extends about 3.7 miles upstream. 

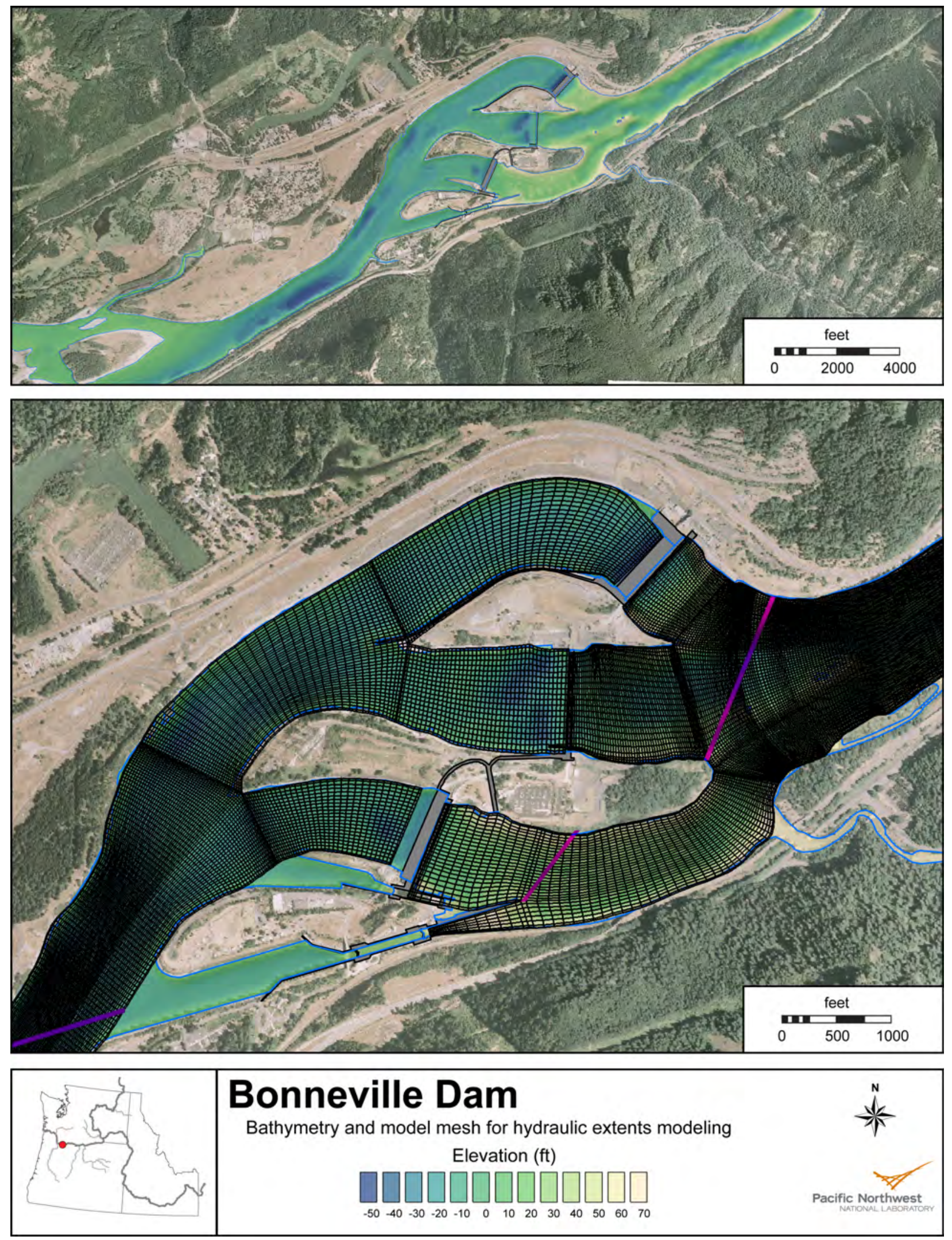

Figure 2.1. Bathymetry and Computational Mesh near the Bonneville Project. The upper panel shows the overall river bathymetry. The lower panel shows the bathymetry, computational mesh near the dam, and the BRZ (pink line). 

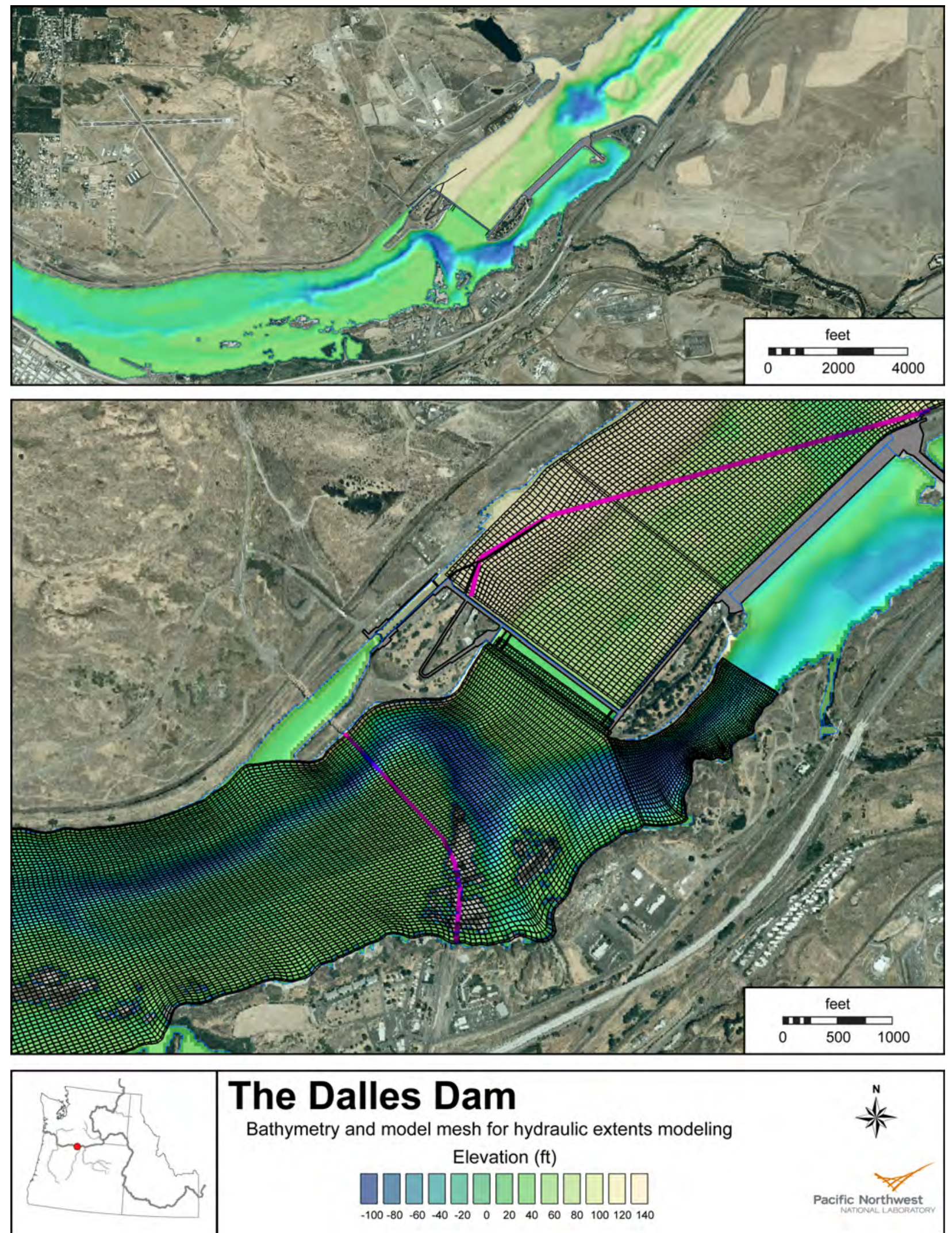

\section{The Dalles Dam}

Bathymetry and model mesh for hydraulic extents modeling
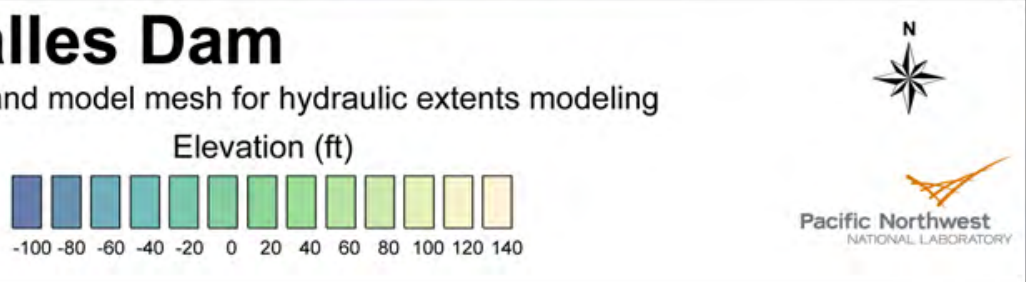

Figure 2.2. Bathymetry and Computational Mesh near The Dalles Project. The upper panel shows the overall river bathymetry. The lower panel shows the bathymetry, computational mesh near the dam, and the BRZ (pink line). 
In the JDA tailrace (Figure 2.3), the mesh had one cell per spillbay, two per turbine unit. The island complex just downstream of the project was included in the mesh, allowing the modeling of the inundation of this complex. The area of increased cross-stream resolution extended 4.5 miles downstream.

\subsubsection{John Day Pool}

In the JDA forebay (Figure 2.3), the mesh has one cell per spillbay and per turbine unit. The area of increased cross-stream resolution extends 5.5 miles upstream.

At the MCN tailrace, the area of increased resolution extends only 2 miles downstream; however, a flow constriction makes the reduction in cross-stream cell numbers not as much of a change in cross-stream spatial resolution. At the dam, (Figure 2.4) there is one cell per spill bay, and two per turbine unit.)

\subsubsection{McNary Pool up to Ice Harbor Dam}

In the MCN forebay, the spillbays and turbine units have one cell each (Figure 2.4), and the area of increased cross-stream resolution extends 6 miles upstream. This mesh includes a short section of the Columbia upstream of its confluence with the Snake River and a well-resolved section of the Snake from Ice Harbor Dam to the Columbia River confluence.

At IHR, the mesh was taken from another study (Hanrahan et al.2007). This well-resolved mesh has two cells per spillway bay and per turbine unit (Figure 2.5). This mesh has two locations, both near the confluence, where the mesh has 2:1 cross-stream matches across block boundaries to reduce the number of cells.

Above IHR, the river tends to have more convoluted shorelines. In many places, the mesh boundaries are outside the convolutions to increase mesh orthogonality while letting the wetting/drying capabilities determine the portions of the mesh that are within the flowing river. In the IHR forebay, there is one cell per bay and turbine unit (Figure 2.5), but more cells were added in upstream blocks to maintain cross stream resolution because the river and mesh are wider. In the LMN tailrace, there are two cells per turbine unit and spillbay (Figure 2.6.).

\subsubsection{Lower Monumental Pool}

In the LMN forebay, there is one cell per turbine unit and spillbay (Figure 2.6). The shorelines for this pool extend outside much of the pool to include shoreline complexity and side channels while maintaining a sufficient number of cells in the main channel. In the Little Goose tailrace, there is one cell per spillbay, two per turbine unit (Figure 2.7).

In the LGO forebay, the computational mesh has one cell per turbine unit and spillbay (Figure 2.7). In the LGR tailrace, there are two cells per turbine unit and spillbay (Figure 2.8).

The mesh extends from LGR to 3.5 miles upstream of the Clearwater confluence and includes 

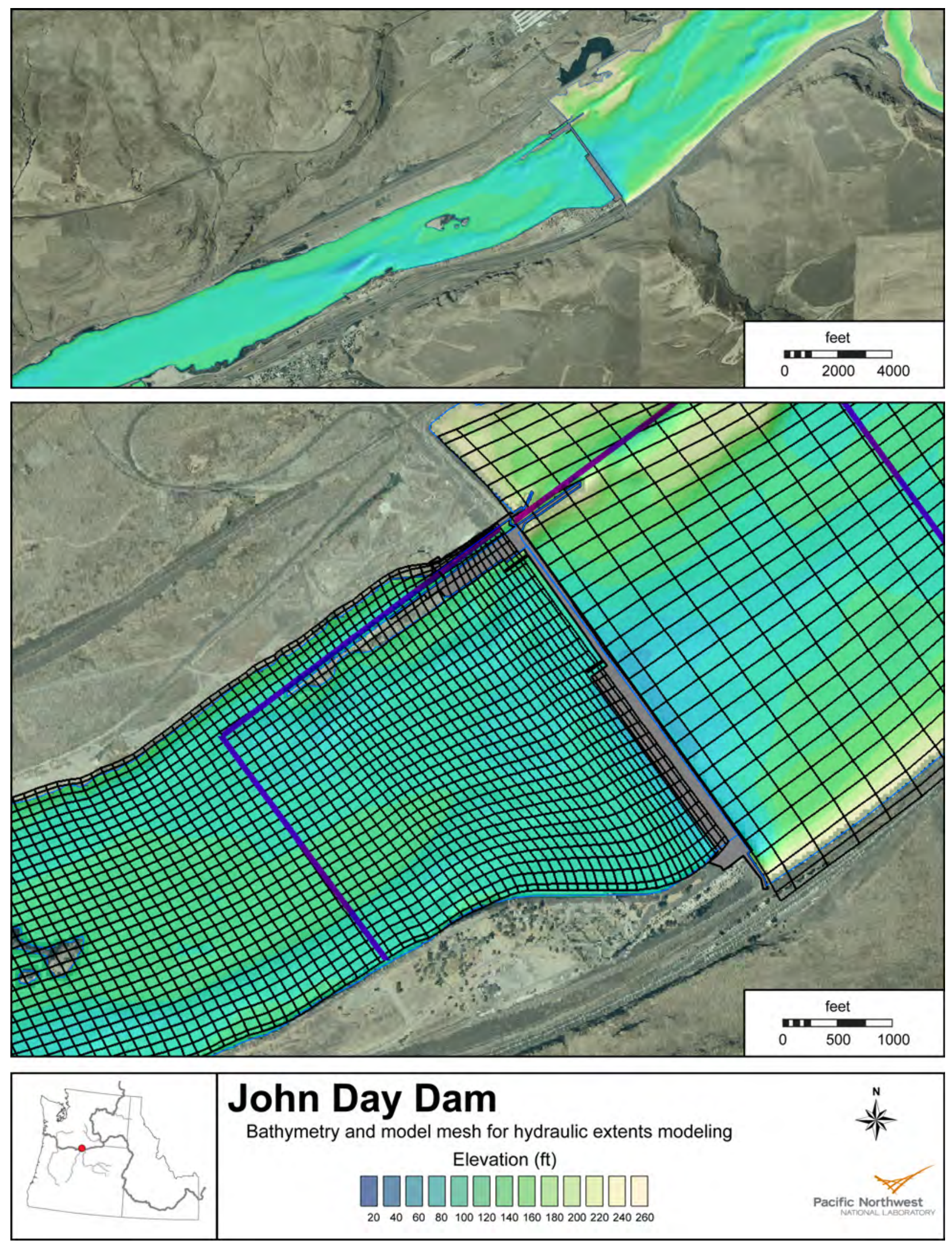

Figure 2.3. Bathymetry and Computational Mesh near the John Day Project. The upper panel shows the overall river bathymetry. The lower panel shows the bathymetry, computational mesh near the dam, and the BRZ (pink line). 

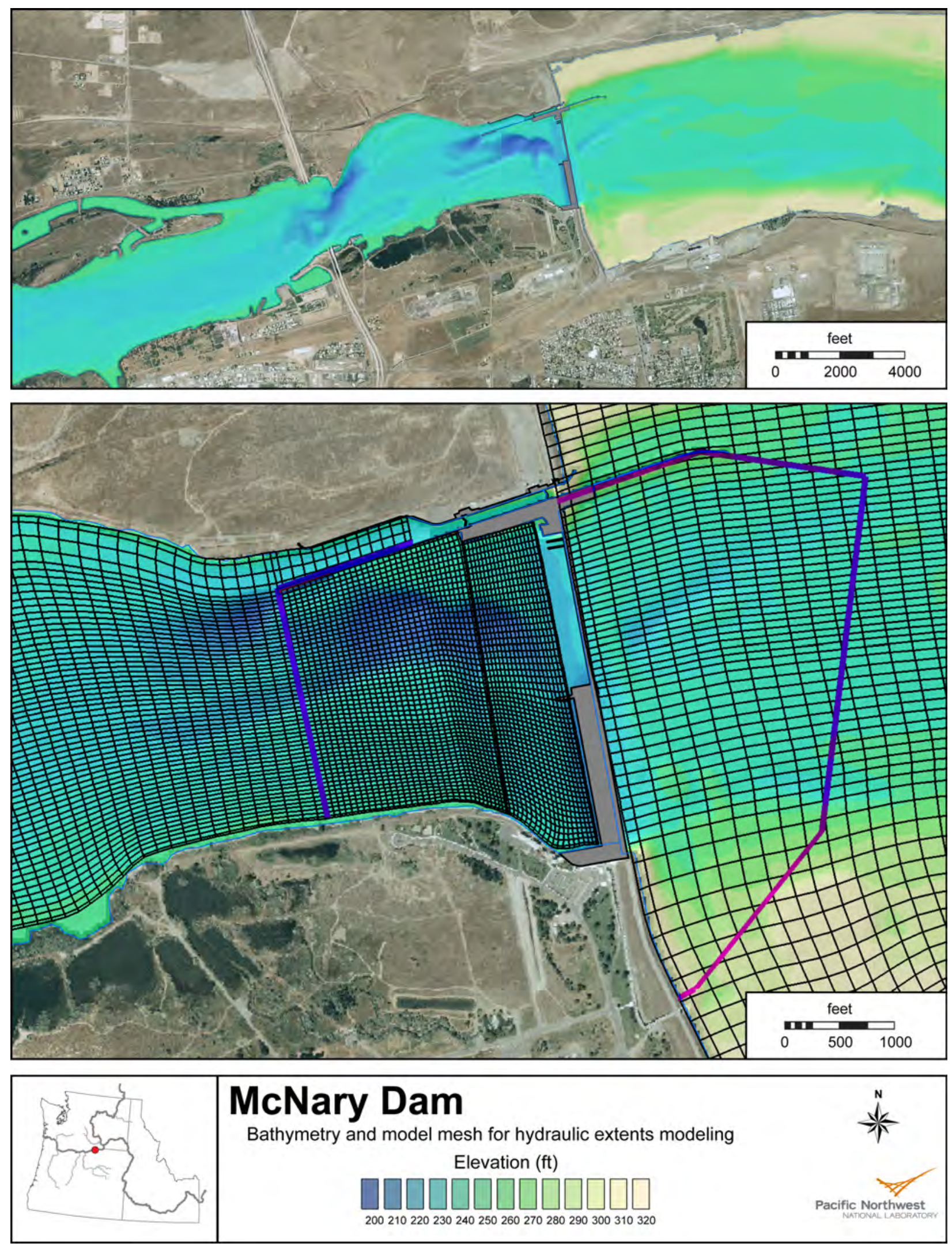

Figure 2.4. Bathymetry and Computational Mesh near the McNary Project. The upper panel shows the overall river bathymetry. The lower panel shows the bathymetry, computational mesh near the dam, and the BRZ (pink line). 

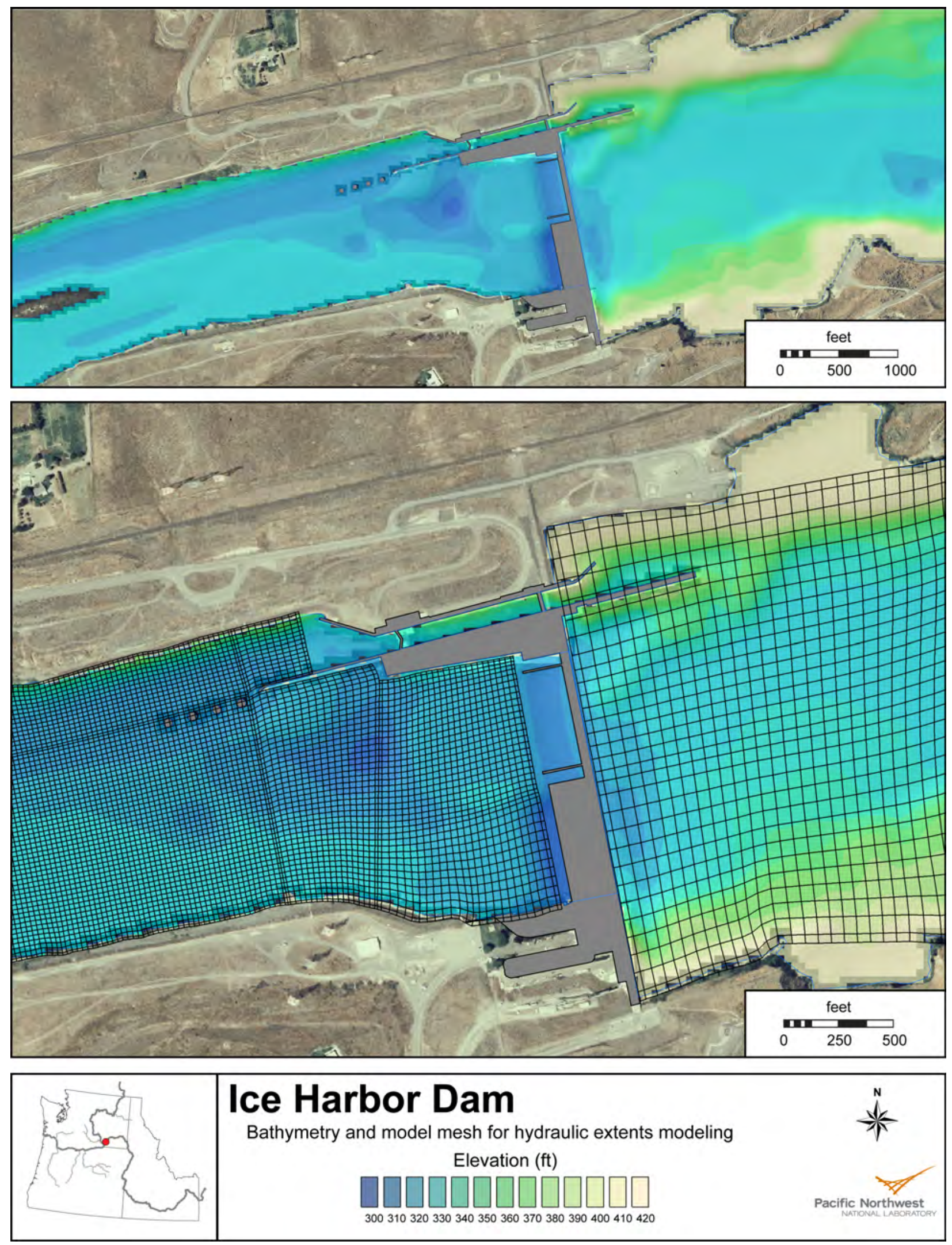

Figure 2.5. Bathymetry and Computational Mesh near the Ice Harbor Project. The upper panel shows the overall river bathymetry. The lower panel shows the bathymetry and computational mesh near the dam. 

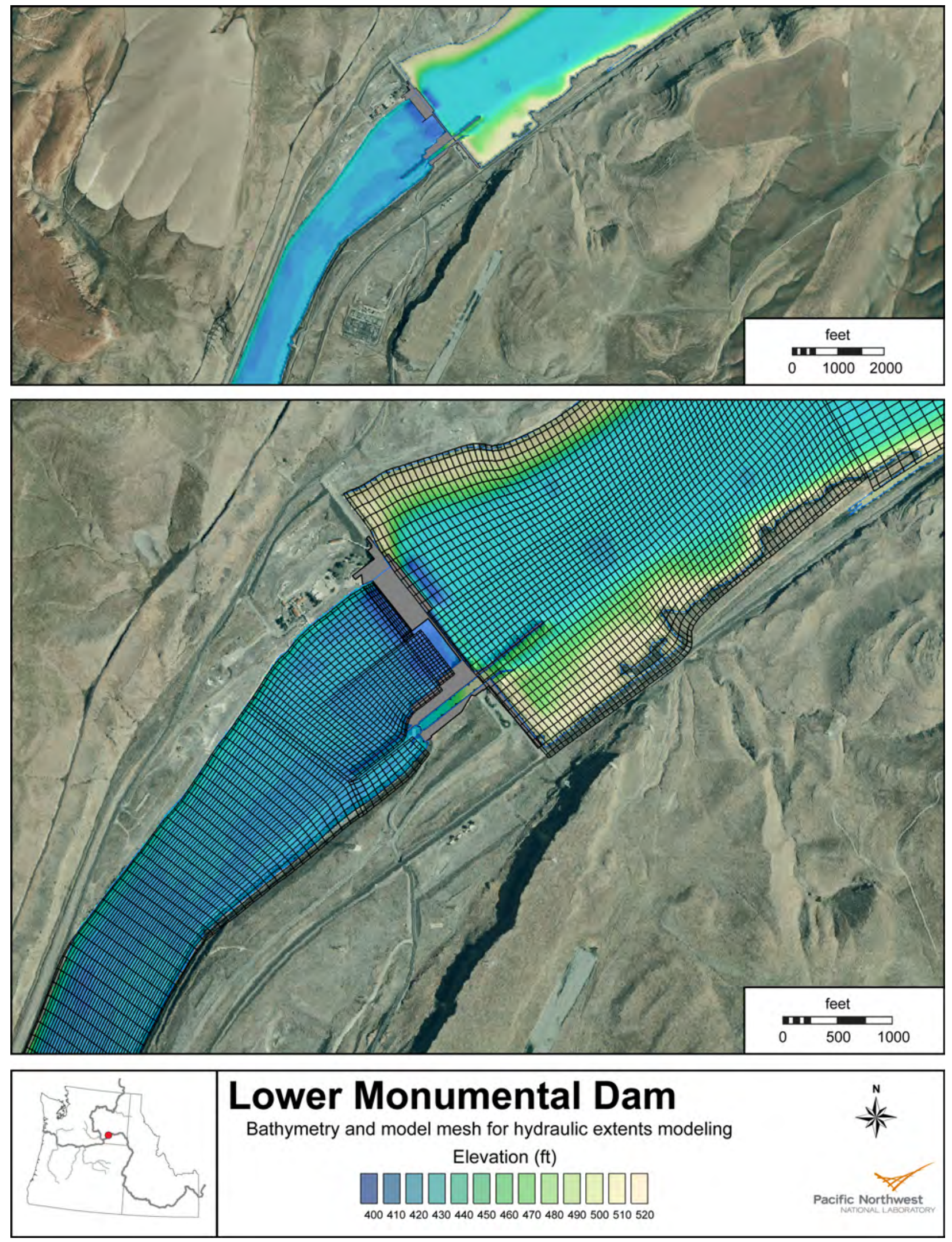

Figure 2.6. Bathymetry and Computational Mesh near the Lower Monumental Project. The upper panel shows the overall river bathymetry. The lower panel shows the bathymetry and computational mesh near the dam. 

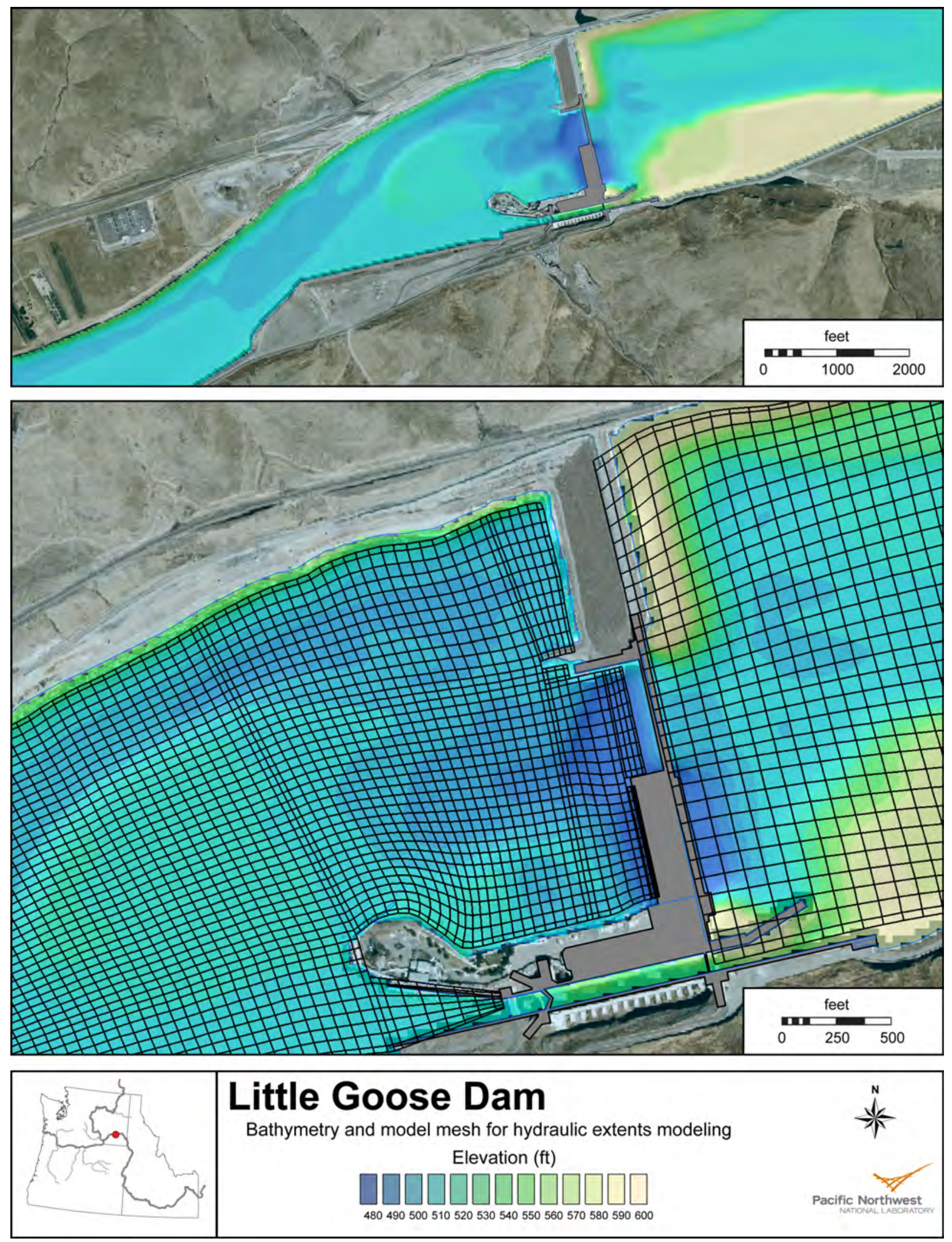

Figure 2.7. Bathymetry and Computational Mesh near the Little Goose Project. The upper panel shows the overall river bathymetry. The lower panel shows the bathymetry and computational mesh near the dam. 

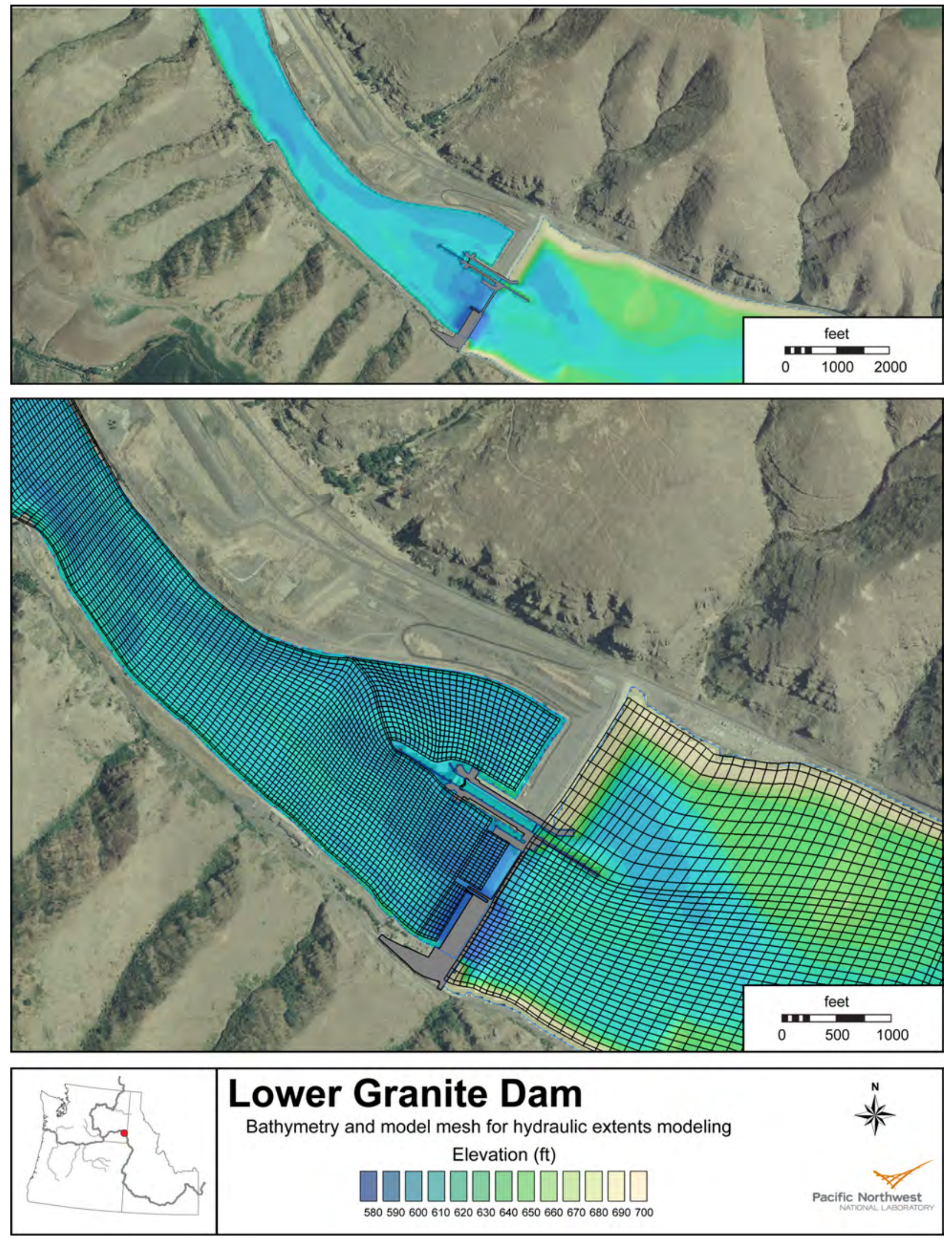

Figure 2.8. Bathymetry and Computational Mesh near the Lower Granite Project. The upper panel shows the overall river bathymetry. The lower panel shows the bathymetry and computational mesh near the dam. 
a 7-mile segment of the Clearwater River. In the LGR forebay, there are two cells per turbine unit and one per spill bay (Figure 2.8). The shallow draft boom that extends attaches between the powerhouse and spillway and extends upstream to the south shore was ignored, per guidance from CENWW.

\subsection{Model Configuration and Scenarios}

The project operations were specified by CENWP and CENWW for each project. For each project, the forebay and tailrace models both needed to be configured and run for each specified operation.

The forebay models were configured with a specified total river flow at the next dam upstream and bay-by-bay, unit-by-unit operations in the forebay. A single bay was specified as a water surface elevation boundary so as to not over constrain the model. As model conditions changed, this "open" boundary allowed the forebay hydraulics to adjust more quickly to changing boundary conditions. Travel time data provided by CENWP and CENWW were used to estimate the time needed for a steady state to be achieved after changing the total river flow for a given reach and flow. One day of time was typically used for changing project operations for the same total river flow.

For the tailrace models, bay-by-bay, unit-by-unit operations were specified at the project, and the downstream boundary was run as a specified water surface elevation.

For all river reaches, the most recent validated Manning's n value was used. New meshes, however, were not re-validated against field measured data. Time steps small enough to have convergent models were used. Time steps were typically $30 \mathrm{~s}$, although $15 \mathrm{~s}$ were used in some models.

The boundary condition spreadsheets were used to create the ASCII text files required as input files for MASS2. Each total river flow was run to to a converged steady-state solution for particular total river discharge, and then the model was run for an additional $24 \mathrm{~h}$ before writing the modeled flows for each operational scenario. MASS2 writes out the dates associated with model output, and those dates are used to track the scenario.

Water mass imbalances were checked for all model runs to ensure convergence. The typical allowed imbalance was $100 \mathrm{cfs}$; however, most runs had a much smaller block imbalance ( 1 cfs). Flow volumes were checked to make sure the model was properly configured and converged. Inflow and outflow locations at the projects were checked to make sure that the unit numbering was correct in the configuration files and flow locations were properly assigned.

\subsubsection{General MASS2 Configuration}

A MASS2 simulation case is configured using a series of text files for the computational mesh, model parameters, and flow conditions (see Perkins and Richmond (2004b) for details). In this study, a large range of flows was simulated. In the lower Columbia, the range of total river flows 
were from the lower typical summers flows to the maximum flows at which the Fish Passage Plan (FPP) (USACE-Northwestern Division 2008) can be used. At higher flows, there would be involuntary spill. The operations at each project were for the minimum and maximum powerhouse loading. For the Snake River dams and McNary Dam, the range was from minimum flow to high flows. The specified project operations were selected to explore the largest possible differences by modeling maximum powerhouse or minimum powerhouse flow. Additional runs had the flow centered mid-river for the maximum momentum concentration. Specific project operations are detailed in the sections below.

\subsubsection{Bonneville Project}

At Bonneville, the river is split by two islands with a spillway between the two islands, Powerhouse 1 (B1) between Bradford Island and the Oregon shore, and Powerhouse 2 (B2) between Cascade Island and Washington shore. Flow distributions were specified to include priority flow in both powerhouses and the spillway, but only for flow patterns that would be allowed operations (Tables 2.10 and 2.11). The spillway had an almost flat pattern: the spill flow was evenly distributed between Bays 2 to 17, but half the flow volume in Bays 1 and 18. Total spill flow was divided by 17 to get the unit flow; that unit flow was used in Bays 2-12, and half that flow was used in Bays 1 and 18.

Table 2.10. Bonneville Scenarios

\begin{tabular}{lccccc}
\hline Case & Description & $\begin{array}{c}\text { Total River } \\
(\mathrm{kcfs})\end{array}$ & $\begin{array}{c}\text { B1 } \\
(\mathrm{kcfs})\end{array}$ & $\begin{array}{c}\text { B2 } \\
(\mathrm{kcfs})\end{array}$ & $\begin{array}{c}\text { Spillway } \\
(\mathrm{kcfs})\end{array}$ \\
\hline 1 & Typical summer flow, Existing FPP & 150 & 60 & & 90 \\
2 & Typical summer flow, Full B1 & 150 & 120 & 30 & \\
3 & Typical summer flow, Full B2 & 150 & & 150 & \\
4 & Typical spring flow, Min. PH loading & 250 & & 150 & 100 \\
5 & Typical spring flow, Existing FPP & 250 & 120 & & 130 \\
6 & Typical spring flow, Max. PH & 250 & 100 & 150 & \\
7 & Max flow for FPP, Min. PH, B2 & 350 & & 30 & 320 \\
8 & Max flow for FPP, Min. PH, B1 & 350 & 30 & & 320 \\
9 & Max flow for FPP, B2 priority, B1 & 350 & 100 & 150 & 100 \\
10 & High flow, Min. PH, B1 & 450 & 0 & 30 & 420 \\
11 & High flow, Min. PH, B2 & 450 & 30 & 0 & 420 \\
12 & High flow, Max. PH & 450 & 100 & 150 & 200 \\
\hline
\end{tabular}




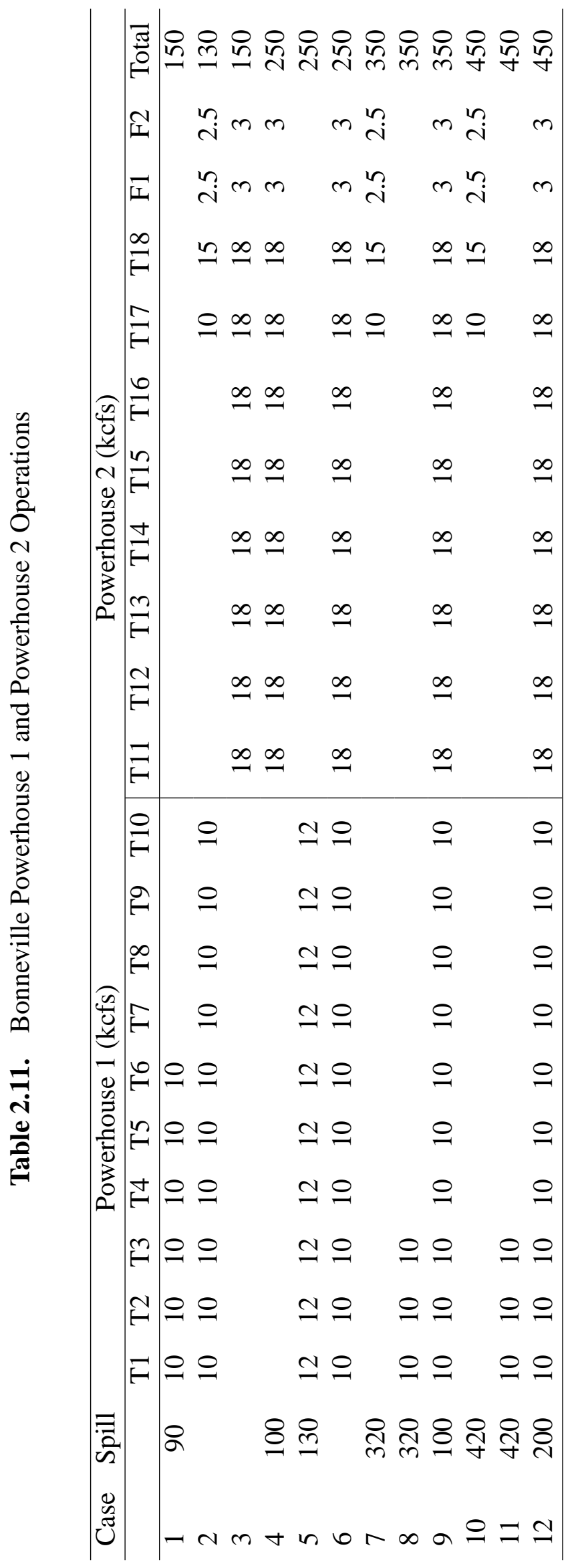




\subsubsection{The Dalles Project}

A summary of flows is in Table 2.12 with with unit-by-unit details of flow distribution in Table 2.13.

Table 2.12. The Dalles Scenarios

\begin{tabular}{lcccc}
\hline Case & Description & $\begin{array}{c}\text { Total River } \\
(\mathrm{kcfs})\end{array}$ & $\begin{array}{c}\text { Powerhouse } \\
(\mathrm{kcfs})\end{array}$ & $\begin{array}{c}\text { Spillway } \\
(\mathrm{kcfs})\end{array}$ \\
\hline 1 & Summer flow, Min. PH & 150 & 50 & 100 \\
2 & Summer flow, Existing FPP & 150 & 90 & 60 \\
3 & Summer flow, Full PH, no spill & 150 & 150 & 0 \\
4 & Spring flow, Min. PH & 250 & 50 & 200 \\
5 & Spring flow, Existing FPP, 40\% spill & 250 & 150 & 100 \\
6 & Spring flow, Max. PH, no spill & 250 & 250 & 0 \\
7 & Spring flow at Max. PH, Min. PH & 270 & 50 & 220 \\
8 & Spring flow at Max. PH, Existing FPP, 40\% spill & 270 & 162 & 108 \\
9 & Spring flow at Max. PH, Max. PH, no spill & 270 & 270 & 0 \\
10 & High Flow, Min. PH & 450 & 50 & 400 \\
11 & High Flow, Max. PH, 40\% spill & 450 & 270 & 180 \\
\hline
\end{tabular}




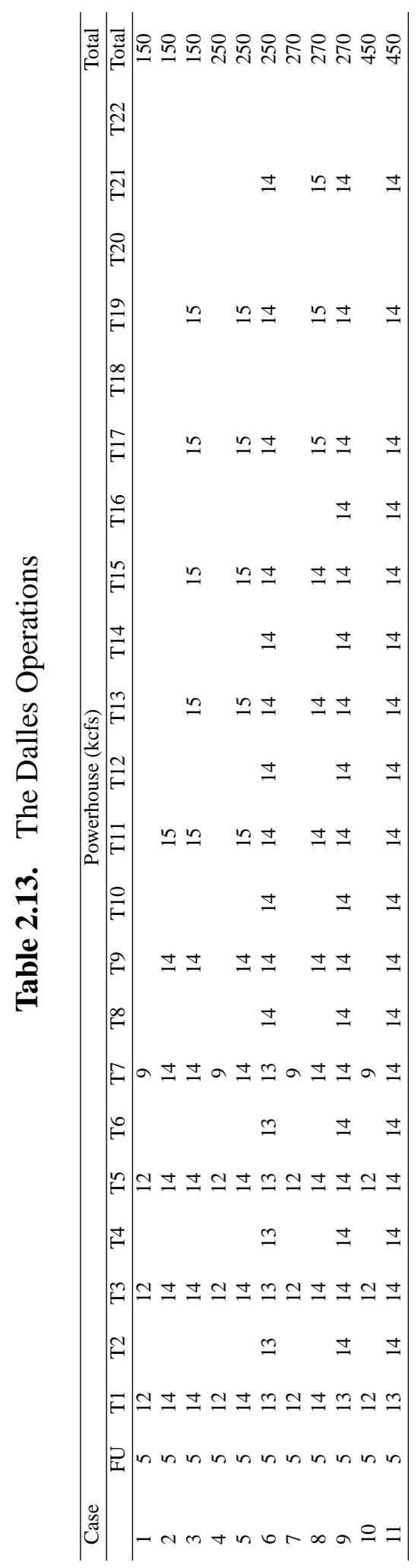




\subsubsection{John Day Project}

These runs were previously reported in Rakowski et al. (2008b). However, the analysis of the simulation results evolved since the initial work. For completeness, the runs and results in consistent format are reported here. CENWP specified 11 flow scenarios to be run (Table 2.14) for four total river flows. For each given flow, a scenario for minimum powerhouse, full powerhouse, and an existing FPP operation was run. In the case of the $450 \mathrm{kcfs}$ Total River, the maximum powerplant capacity case is almost identical to the existing FPP Pattern. Hence, there are two rather than three scenarios for a $450 \mathrm{kcfs}$ Total River. The difference between "Full $\mathrm{PH}$ " and "Max. PH" in Table 2.14 is that for the full powerhouse, the turbines are operated within the $1 \%$ range of peak efficiency, and the maximum is passing the most water possible through the powerhouse.

Table 2.14. John Day Project Scenarios

\begin{tabular}{lcccc}
\hline Case & Description & $\begin{array}{c}\text { Total River } \\
(\mathrm{kcfs})\end{array}$ & $\begin{array}{c}\text { Spillway } \\
(\mathrm{kcfs})\end{array}$ & $\begin{array}{c}\text { Powerhouse } \\
(\mathrm{kcfs})\end{array}$ \\
\hline 1 & Typical Summer, Min. PH & 150 & 100 & 50 \\
2 & Typical Summer, Existing FPP & 150 & 45 & 105 \\
3 & Typical Summer, Full PH & 150 & 0 & 150 \\
4 & Typical Med. Flow, Min. PH & 250 & 200 & 50 \\
5 & Typical Med. Flow, Existing FPP & 250 & 75 & 175 \\
6 & Typical Med. Flow, Full PH & 250 & 0 & 250 \\
7 & Spring Flow, Min. PH & 320 & 270 & 50 \\
8 & Spring Flow,Existing FPP & 320 & 96 & 224 \\
9 & Spring Flow, Max. PH & 320 & 0 & 320 \\
10 & High Flow with FPP, Min. PH & 450 & 400 & 50 \\
11 & High Flow with FPP, Existing FPP & 450 & 135 & 315 \\
\hline
\end{tabular}




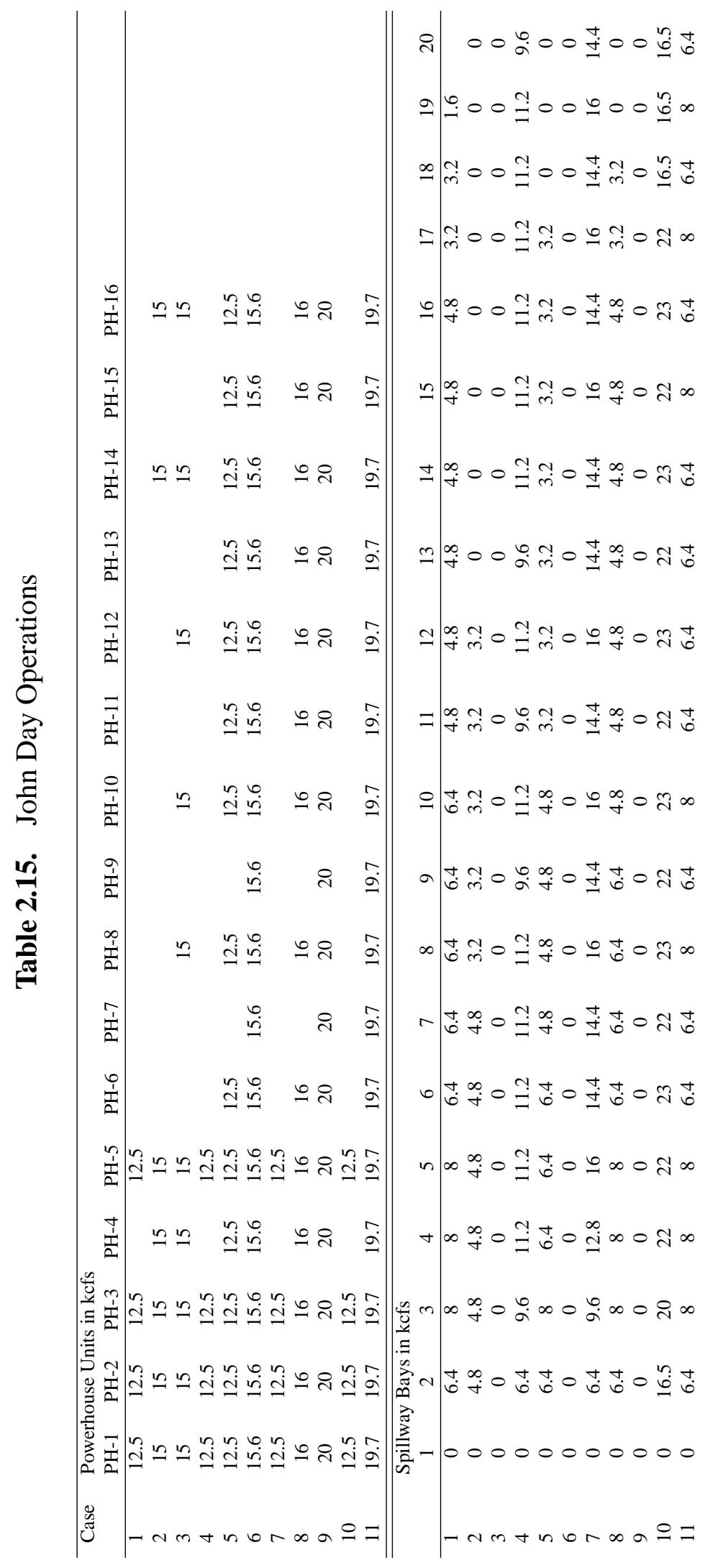




\subsubsection{McNary Project}

CENWW hydro projects (the lower Snake River dams and McNary Dam), the flows were determined somewhat differently. For each project, simulations were run for the range of total river flows: minimum flow, low flow, medium flow, and high flow. For each total river flow, operations for the maximum and minimum powerhouse flows were simulated. In addition, for the minimum and low flows, an additional simulation was run with the flow at the project being in the center of the river. A summary of flows is in Table 2.16 with unit-by-unit details of flow distribution in Table 2.17

Table 2.16. McNary Scenarios

\begin{tabular}{lcccc}
\hline Case & Description & $\begin{array}{c}\text { Total River } \\
(\mathrm{kcfs})\end{array}$ & $\begin{array}{c}\text { Spillway } \\
(\mathrm{kcfs})\end{array}$ & $\begin{array}{c}\text { Powerhouse } \\
(\mathrm{kcfs})\end{array}$ \\
\hline 1 & Min. Flow, Min. PH & 100 & 50 & 50 \\
2 & Min. Flow, Max. PH & 100 & 0 & 100 \\
3 & Low Flow, Min. PH & 150 & 100 & 50 \\
4 & Low Flow, Max. PH & 150 & 0 & 150 \\
5 & Mid Flow, Min. PH & 250 & 200 & 50 \\
6 & Mid Flow, Max. PH & 250 & 75 & 175 \\
7 & High Flow, Min. PH & 350 & 300 & 50 \\
8 & High Flow, Max. PH & 350 & 175 & 175 \\
9 & Max. PH Flow, Max. PH & 175 & 0 & 175 \\
10 & Min. Flow, Max. Center & 100 & 50 & 50 \\
11 & Low Flow, Max. Center & 150 & 75 & 75 \\
\hline
\end{tabular}




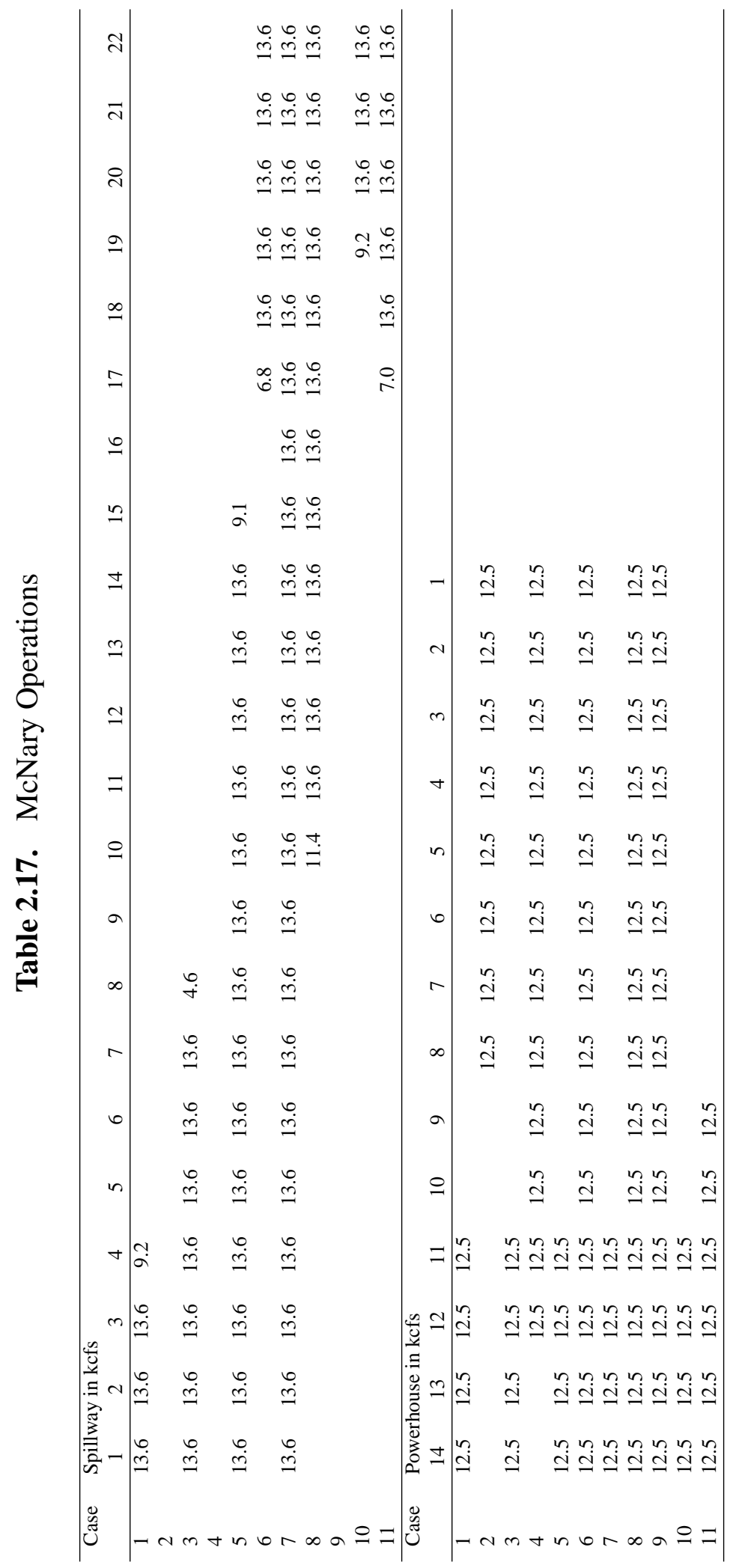




\subsubsection{Ice Harbor Project}

A summary of flows is in Table 2.18 with with unit-by-unit details of flow distribution in Table 2.19.

Table 2.18. Ice Harbor Scenarios

\begin{tabular}{lcccc}
\hline Case & Description & $\begin{array}{c}\text { Total River } \\
(\mathrm{kcfs})\end{array}$ & $\begin{array}{c}\text { Spillway } \\
(\mathrm{kcfs})\end{array}$ & $\begin{array}{c}\text { Powerhouse } \\
(\mathrm{kcfs})\end{array}$ \\
\hline 1 & Min. Flow, Min. PH & 19 & 0 & 11 \\
2 & Min. Flow, Max. PH & 19 & 0 & 19 \\
3 & Low Flow, Min. PH & 30 & 19 & 11 \\
4 & Low Flow, Max. PH & 30 & 0 & 30 \\
5 & Mid Flow, Min. PH & 85 & 74 & 11 \\
6 & Mid Flow, Max. PH & 85 & 0 & 85 \\
7 & High Flow, Min. PH & 120 & 109 & 11 \\
8 & High Flow, Max. PH & 120 & 21 & 99 \\
9 & Max. PH Flow, Max. PH & 99 & 0 & 99 \\
10 & Min. Flow, Max. Center & 19 & 10 & 9 \\
11 & Low Flow, Max. Center & 30 & 15 & 15 \\
\hline
\end{tabular}




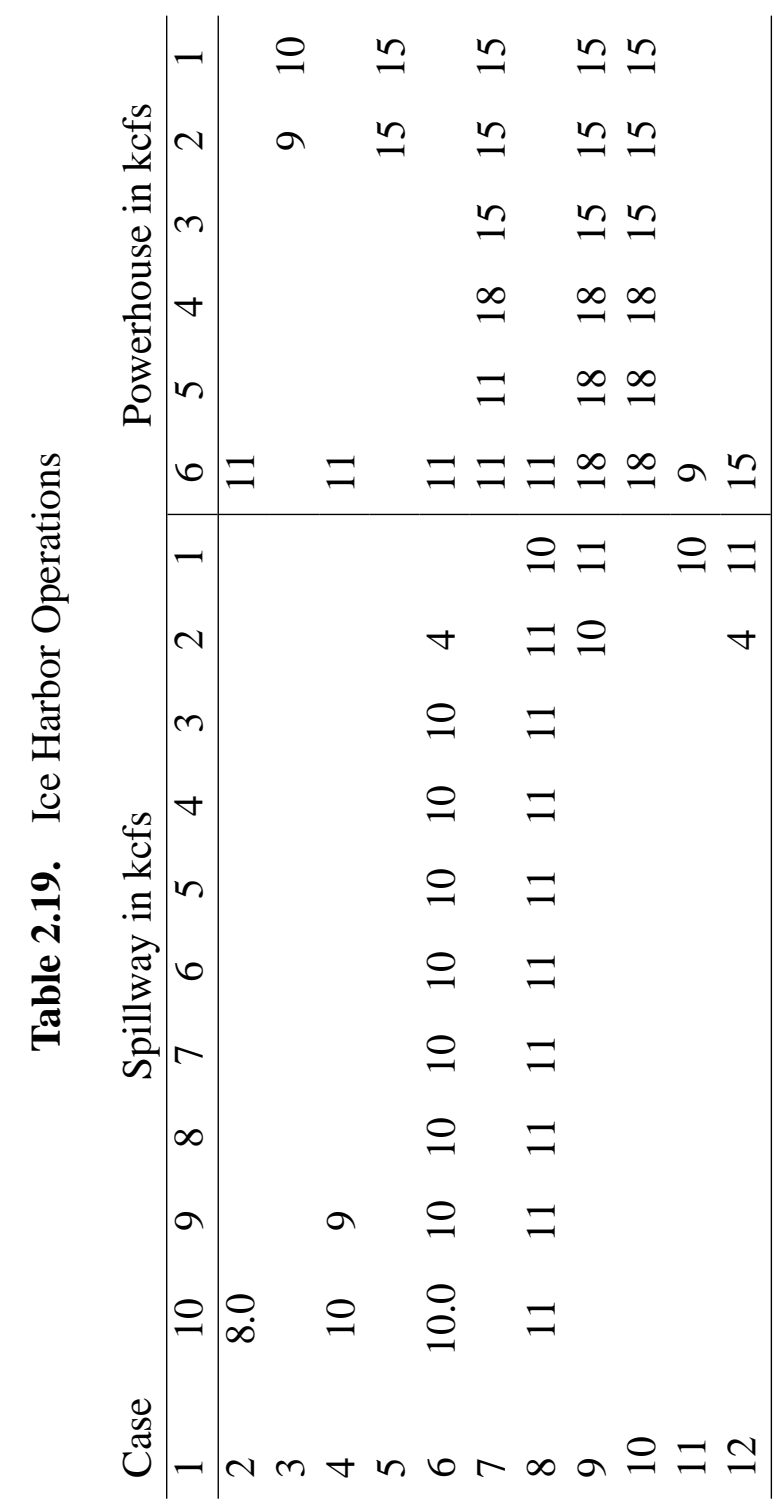




\subsubsection{Lower Monumental Project}

A summary of flows is in Table 2.20 with unit-by-unit details of flow distribution in Table 2.21 .

Table 2.20. Lower Monumental Scenarios

\begin{tabular}{lcccc}
\hline Case & Description & $\begin{array}{c}\text { Total River } \\
(\mathrm{kcfs})\end{array}$ & $\begin{array}{c}\text { Spillway } \\
(\mathrm{kcfs})\end{array}$ & $\begin{array}{c}\text { Powerhouse } \\
(\mathrm{kcfs})\end{array}$ \\
\hline 1 & Min. Flow, Min. PH & 19 & 5 & 14 \\
2 & Min. Flow, Max. PH & 19 & 0 & 19 \\
3 & Low Flow, Min. PH & 30 & 16 & 14 \\
4 & Low Flow, Max. PH & 30 & 0 & 30 \\
5 & ADCP 4/30/2010 & 62 & 27 & 35 \\
6 & Mid Flow, Min. PH & 85 & 71 & 14 \\
7 & Mid Flow, Max. PH & 85 & 0 & 85 \\
8 & High Flow, Min. PH & 120 & 106 & 14 \\
9 & High Flow, Max. PH & 120 & 0 & 120 \\
10 & Mid Flow, Typical & 85 & 27 & 58 \\
11 & Min Flow, Max Center & 19 & 5 & 14 \\
12 & Low Flow, Max Center & 30 & 13.3 & 16.7 \\
\hline
\end{tabular}

Table 2.21. Lower Monumental Operations

\begin{tabular}{|c|c|c|c|c|c|c|c|c|c|c|c|c|c|c|}
\hline Case & & Powe & hous & Un & s (kcf & & & & & lway & ays (1 & & & \\
\hline & 1 & 2 & 3 & 4 & 5 & 6 & 8 & 7 & 6 & 5 & 4 & 3 & 2 & 1 \\
\hline 1 & & & & & & 14 & & & & & & & & 5 \\
\hline 2 & 19 & & & & & & & & & & & & & \\
\hline 3 & & & & & & 14 & & & & & & & 6 & 10 \\
\hline 4 & 15 & 15 & & & & & & & & & & & & \\
\hline 5 & & 17.5 & & & 17.5 & & 7 & & 9 & 3 & 2 & 2 & 2 & 2 \\
\hline 6 & & & & & & 14 & & 10 & 10 & 10 & 10 & 10 & 10 & 11 \\
\hline 7 & 20 & 20 & 15 & 15 & 15 & & & & & & & & & \\
\hline 8 & & & & & & 14 & 13.3 & 13.3 & 13.3 & 13.3 & 13.3 & 13.3 & 13.3 & 13.3 \\
\hline 9 & 20 & 20 & 20 & 20 & 20 & 20 & & & & & & & & \\
\hline 10 & & 14 & 14 & 15 & 15 & & 7.6 & & 8.9 & 3.3 & 1.8 & 1.8 & 1.8 & 1.8 \\
\hline 11 & & & & & & 14 & 5 & & & & & & & \\
\hline 12 & & & & & & 16.7 & 13.3 & & & & & & & \\
\hline
\end{tabular}




\subsubsection{Little Goose Project}

A summary of flows is in Table 2.22 with unit-by-unit details of flow distribution in Table 2.23 .

Table 2.22. Little Goose Scenarios

\begin{tabular}{lcccc}
\hline Case & Description & $\begin{array}{c}\text { Total River } \\
(\mathrm{kcfs})\end{array}$ & $\begin{array}{c}\text { Spillway } \\
(\mathrm{kcfs})\end{array}$ & $\begin{array}{c}\text { Powerhouse } \\
(\mathrm{kcfs})\end{array}$ \\
\hline 1 & Min. Flow, Min. PH & 19 & 5 & 14 \\
2 & Min. Flow, Max. PH & 19 & 0 & 19 \\
3 & Low Flow, Min. PH & 30 & 16 & 14 \\
4 & Low Flow, Max. PH & 30 & 0 & 30 \\
5 & Mid Flow, Min. PH & 85 & 71 & 14 \\
6 & Mid Flow, Max. PH & 85 & 0 & 85 \\
7 & High Flow, Min. PH & 120 & 106 & 14 \\
8 & High Flow, Max. PH & 120 & 0 & 120 \\
9 & Mid Flow, Typical & 85 & 27 & 58 \\
10 & Min. Flow, Max. Center & 19 & 5 & 14 \\
11 & Low Flow, Max. Center & 30 & 13.3 & 16.7 \\
\hline
\end{tabular}

Table 2.23. Little Goose Operations

\begin{tabular}{lcccccccc|cccccc}
\hline Case & \multicolumn{10}{c}{ Spillway Bays (kcfs) } & \multicolumn{7}{c}{ Powerhouse (kcfs) } \\
\hline 1 & 8 & 7 & 6 & 5 & 4 & 3 & 2 & 1 & 6 & 5 & 4 & 3 & 2 & 1 \\
\hline 2 & 5 & & & & & & & & 14 & & & & \\
3 & 10 & 6 & & & & & & & & & & & & 19 \\
4 & & & & & & & & & 14 & & & & & \\
5 & 11 & 10 & 10 & 10 & 10 & 10 & 10 & & 14 & & & & \\
6 & & & & & & & & & & 15 & 15 & 15 & 20 & 20 \\
7 & 13.3 & 13.3 & 13.3 & 13.3 & 13.3 & 13.3 & 13.3 & 13.3 & 14 & & & & & \\
8 & & & & & & & & & 20 & 20 & 20 & 20 & 20 & 20 \\
9 & 1.8 & 1.8 & 1.8 & 1.8 & 2.0 & 3.3 & 3.3 & 11.2 & & & 15 & 15 & 14 & 14 \\
10 & & & & & & & & 5 & 14 & & & & & \\
11 & & & & & & & & 13.3 & 16.7 & & & & \\
\hline
\end{tabular}




\subsubsection{Lower Granite Project}

A summary of flows is in Table 2.24 with unit-by-unit details of flow distribution in Table 2.25 .

Table 2.24. Lower Granite Scenarios

\begin{tabular}{lcccc}
\hline Case & Description & $\begin{array}{c}\text { Total River } \\
(\mathrm{kcfs})\end{array}$ & $\begin{array}{c}\text { Spillway } \\
(\mathrm{kcfs})\end{array}$ & $\begin{array}{c}\text { Powerhouse } \\
(\mathrm{kcfs})\end{array}$ \\
\hline 1 & Min. Flow, Min. PH & 19 & 5 & 14 \\
2 & Min. Flow, Max. PH & 19 & 0 & 19 \\
3 & Low Flow, Min. PH & 30 & 16 & 14 \\
4 & Low Flow, Max. PH & 30 & 0 & 30 \\
5 & Mid Flow, Min. PH & 85 & 71 & 14 \\
6 & Mid Flow, Max. PH & 85 & 0 & 85 \\
7 & High Flow, Min. PH & 120 & 106 & 14 \\
8 & High Flow, Max. PH & 120 & 0 & 120 \\
9 & Mid Flow, Typical & 85 & 27 & 58 \\
10 & Min. Flow, Max. PH & 19 & 5 & 14 \\
11 & Low Flow, Min. PH & 30 & 13.3 & 16.7 \\
\hline
\end{tabular}

Table 2.25. Lower Granite Operations

\begin{tabular}{lcccccccc|cccccc}
\hline Case & \multicolumn{10}{c}{ Spillway Bays (kcfs) } \\
\hline & 8 & 7 & 6 & 5 & 4 & 3 & 2 & 1 & 6 & 5 & 4 & 3 & 2 & 1 \\
1 & 5 & & & & & & & & 14 & & & & & \\
2 & & & & & & & & & & & & & & 19 \\
3 & 10 & 6 & & & & & & & 14 & & & & & \\
4 & & & & & & & & & & & & & 15 & 15 \\
5 & 11 & 10 & 10 & 10 & 10 & 10 & 10 & & 14 & & & & \\
6 & & & & & & & & & & 15 & 15 & 15 & 20 & 20 \\
7 & 13.3 & 13.3 & 13.3 & 13.3 & 13.3 & 13.3 & 13.3 & 13.3 & 14 & & & & & \\
8 & & & & & & & & & 20 & 20 & 20 & 20 & 20 & 20 \\
9 & 1.8 & 1.8 & 1.8 & 1.8 & 2 & 3.3 & 3.3 & 11.2 & & & 15 & 15 & 14 & 14 \\
10 & & & & & & & & 5 & 14 & & & & & \\
11 & & & & & & & & 13.3 & 16.7 & & & & & \\
\hline
\end{tabular}




\subsection{Analysis of Simulation Data}

Hydraulic influence is defined as the zone where project flow distributions (operations) impact river flow up- and downstream of the dam. Each distribution of discharges through a dam results in a unique set of hydraulic characteristics, such as flow velocity and water-surface elevation, in the river channel adjacent to the project. As one moves away from the project, the river gradually reverts to a stable flow configuration that is unaffected by flow distributions at the dam. The point at which project operations no longer influence the hydraulic characteristics of the river is the hydraulic extent. Because, theoretically, any change in operations will have at least some infinitesimal influence at all points in the flow domain, a threshold level must be defined to establish a definite boundary.

The strategy presented in this document for locating the hydraulic extent is to simulate a wide range of plausible operating conditions and calculate the differences in hydraulic characteristics among the scenarios. The scenarios typically include maximum spill, maximum powerhouse, and balanced patterns for each of four total river discharges. Only scenarios with the same total river discharge are compared. Velocity magnitude and direction are the two hydraulic characteristics used in this study. The comparison metrics are the maximum spread (S) in velocity magnitude and velocity direction at each point in the model, computed as:

$$
\begin{gathered}
S_{\text {vmag }}=|U|_{\text {max }}-|U|_{\text {min }} \\
S_{\text {dir }}=\left|\theta_{\text {max }}-\theta_{\text {min }}\right|
\end{gathered}
$$

where $|U|$ is the velocity magnitude, and $\theta$ is the velocity direction, in degrees.

Comparison metrics are computed using a script developed in Tecplot $360^{T M}$ (Tecplot, Inc.). The script adds the comparison metrics to a model grid dataset and plots the values for analysis. The metrics are contoured according to proposed threshold spread values.

USACE fishery biologists requested data analysis to determine the project hydraulic extent based on the following criteria:

- For areas where the mean velocities are less than $4 \mathrm{ft} / \mathrm{s}$, the differences in the magnitude water velocity between operations are not greater than $0.5 \mathrm{ft} / \mathrm{sec}$, and/or the differences in water flow direction (azimuth) are not greater than $10^{\circ}$.

- If mean water velocity is $4.0 \mathrm{ft} / \mathrm{s}$ or greater, the boundary is determined using the differences in water flow direction (i.e., not greater than $10^{\circ}$ )

Based on these criteria, and not including areas with a mean velocity of less than $0.1 \mathrm{ft} / \mathrm{s}$ (within the error of the model), a final set of graphics was developed that included data from all flows and all operations. 


\subsection{Results and Discussion}

Results are presented in map format by project for each total river flow (Sections 3.1 to 3.8). For each total river flow, the multiple scenarios were analyzed for average velocity magnitude, spread of velocity magnitude, and the spread in maximum difference in flow direction (azimuth). The method is described in Section 2.5. The BRZ is delineated with a pink line.

In Section 3.9 , the hydraulic extent criteria are applied and summarized.

Although the same computational meshes were used for the tailrace of one project and the forebay of the next project downstream, the operational conditions were specified by project with the same conditions used for the forebay and tailrace. Results are discussed in order from downstream to upstream. The maps are organized with three maps per page, each page dedicated to a total river flow. The top graphic has contours of average velocity magnitude and hence increases with river flow. The middle graphic has contours of the spread in velocity magnitude, and the lower figure has contours of the spread of difference in flow direction.

In general, the downstream (tailrace) extent of the impact of project operations is much greater than the upstream (forebay) extent. The forebays are much deeper than the tailrace, so the approach velocities to the project are much lower, and the absolute velocity difference across the channel is much less. In the tailrace, the impact of changing operations extends much further downstream.

There was also a pattern of response to increasing river flow. In the forebays, the upstream extent of the impact of project operations increased between the low and medium flows, but then the upstream impact decreased at the higher flows. In the tailrace, it is the difference in the direction of flow, rather than the velocity difference, that is most flow dependent. The greatest longitudinal extent of flow direction differences is at the lowest flows. The spread in flow directions decreases as the channel competence is approached or downstream constrictions (either by bank shape or mid-stream islands) regulate the flow direction.

\subsection{Bonneville Project}

Bonneville is the most complex channel setting of this study. The river is split by Cascade and Bradford Islands. Operations are detailed in Tables 2.10 and 2.11. The river is split by the islands into three parts, and each part of the river is controlled by a powerhouse or spillway. Hence, the impacts of varying project operations are very large between the project structure and the confluence of the three parts of the river. Figures 3.1 to 3.4 show the results of the MASS2 runs. Downstream, between the BRZ and the Ives Island complex, the overall channel width is much narrower; the relative constriction helps to limit the downstream extent of the impact of project operations at the higher flows. Note that the spread in velocity magnitude is not much different between $350 \mathrm{kcfs}$ and $450 \mathrm{kcfs}$, nor is there much change in flow direction for any of the total river flows.

In the forebay, the greatest impact of project operations is at $250 \mathrm{kcfs}$. At lower and higher 
flows, the upstream extent is more limited. In the tailrace, the hydraulic extent increases with increasing discharge. 


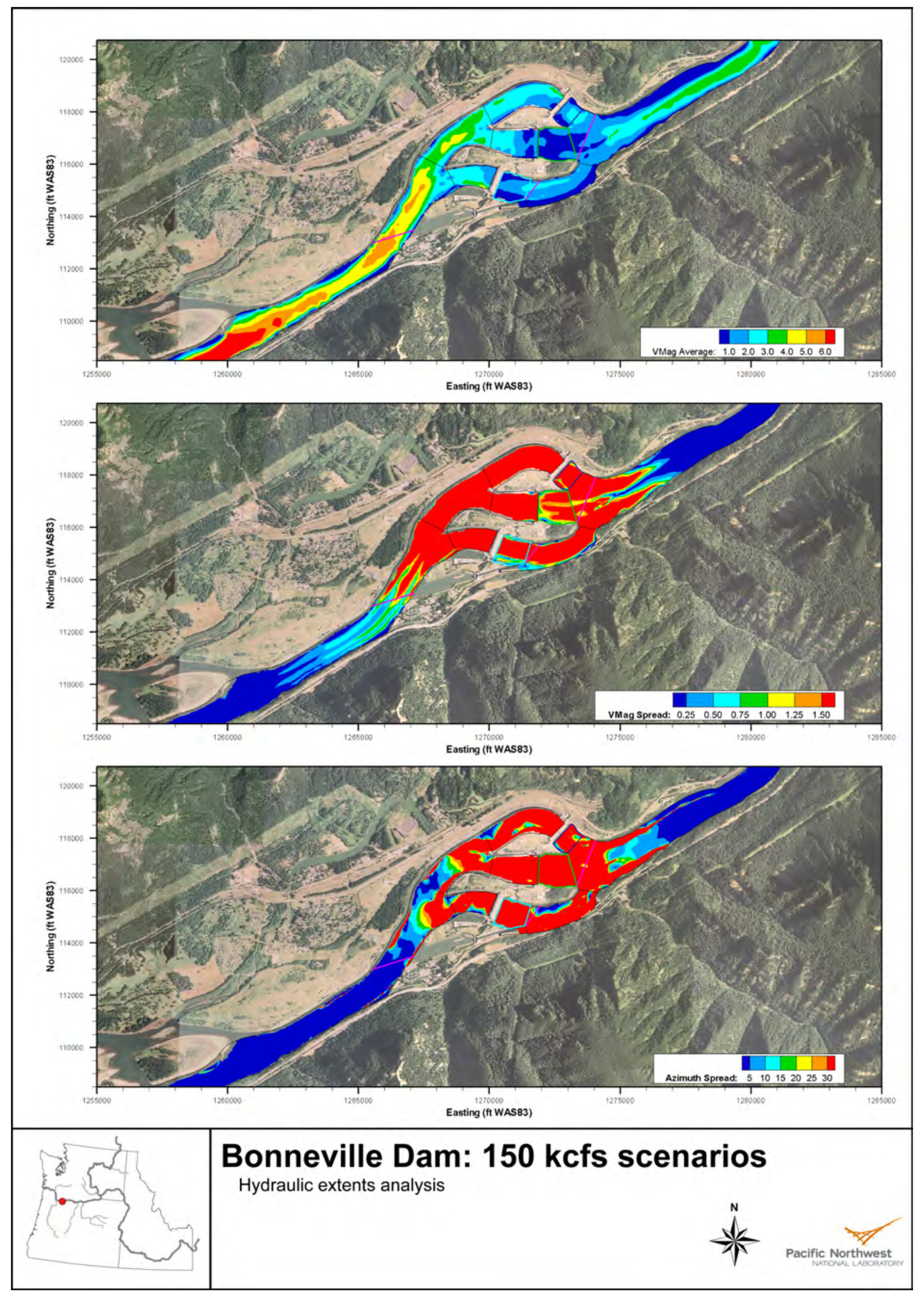

Figure 3.1. Bonneville Dam for $150 \mathrm{kcfs}$. Velocities in $\mathrm{ft} / \mathrm{s}$. 


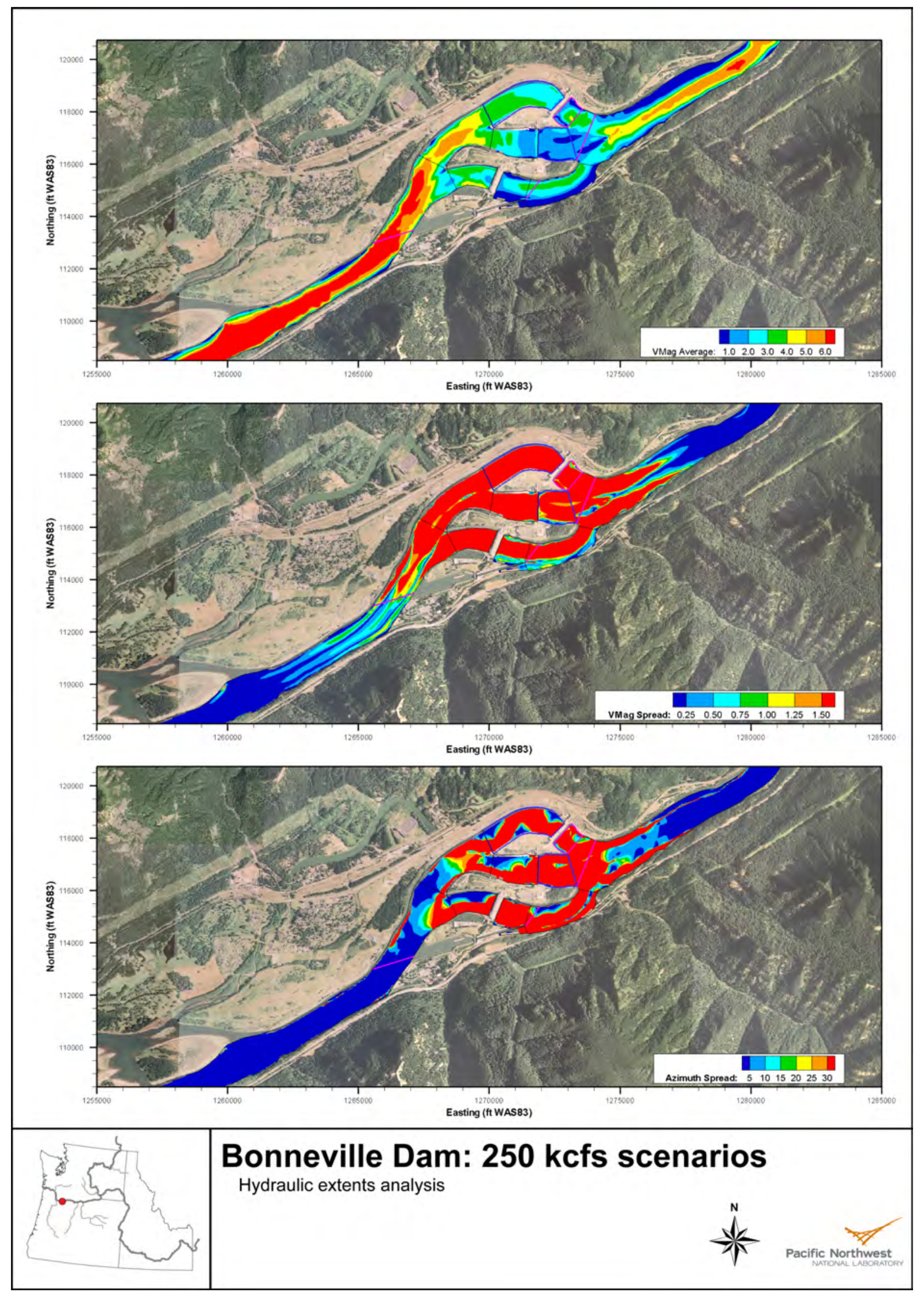

Figure 3.2. Bonneville Dam for $250 \mathrm{kcfs}$. Velocities in $\mathrm{ft} / \mathrm{s}$. 


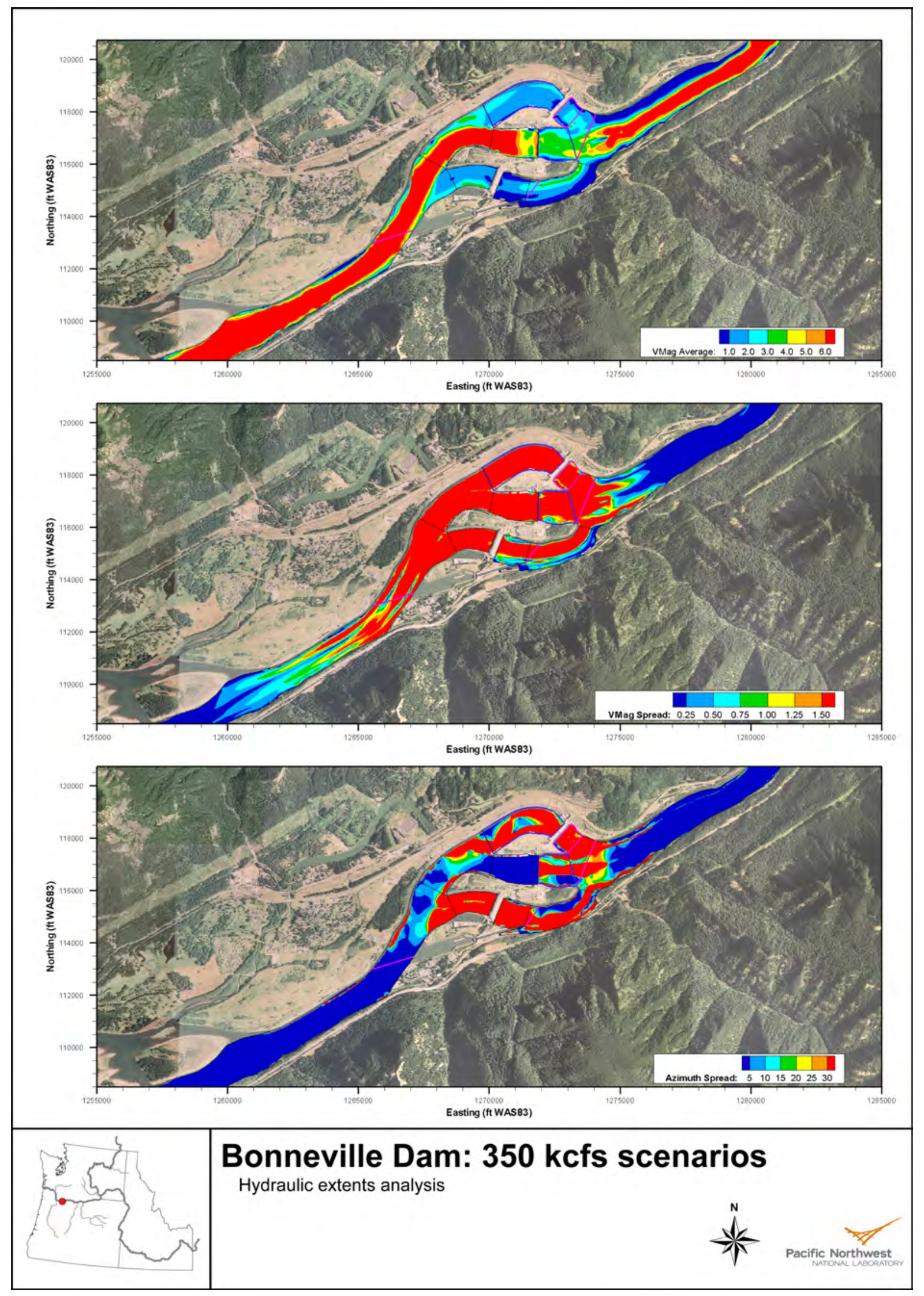

Figure 3.3. Bonneville Dam for $350 \mathrm{kcfs}$. Velocities in $\mathrm{ft} / \mathrm{s}$. 


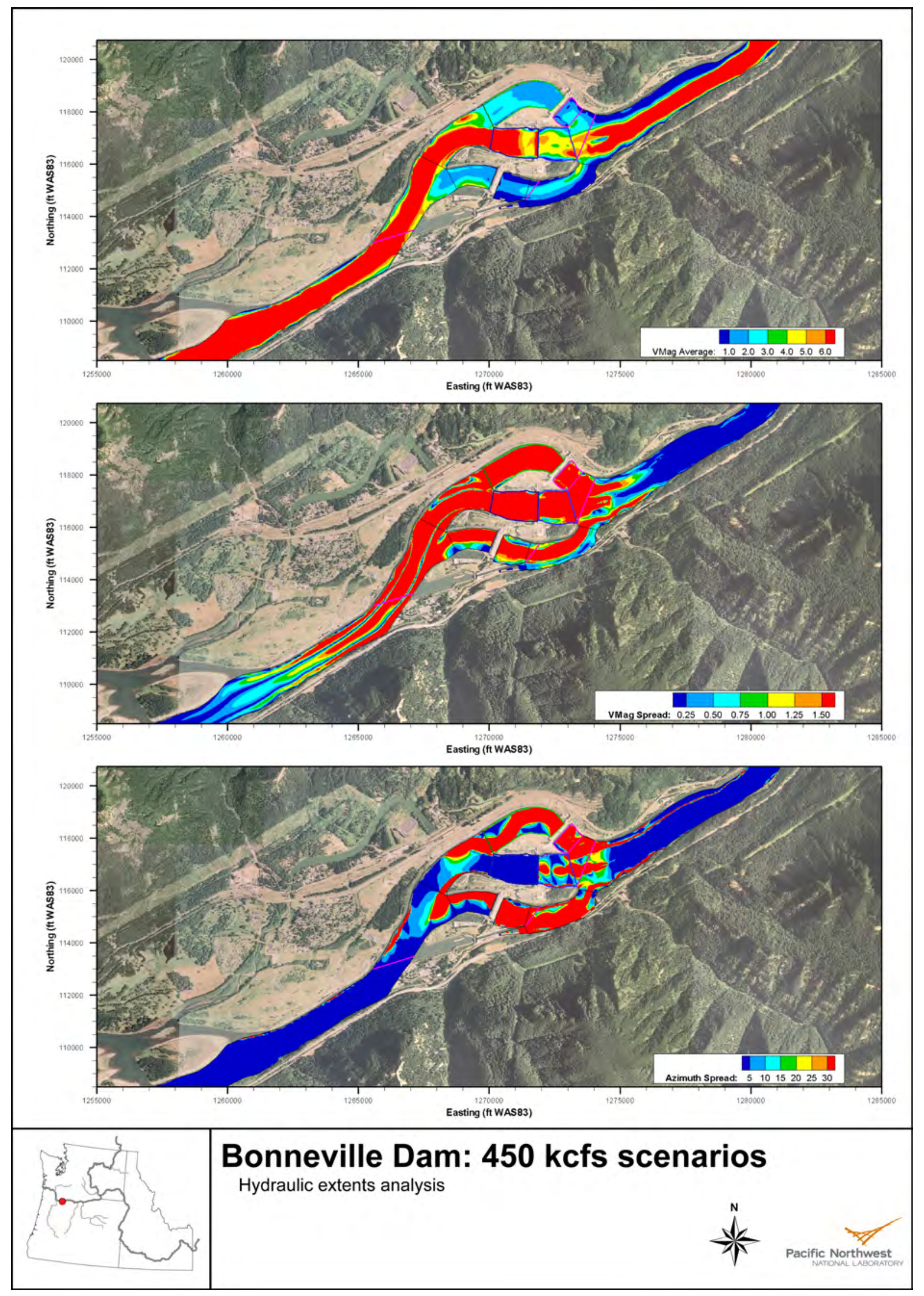

Figure 3.4. Bonneville Dam for $450 \mathrm{kcfs}$. Velocities in $\mathrm{ft} / \mathrm{s}$. 


\subsection{The Dalles Project}

The Dalles has the powerhouse located perpendicular to the thalweg in the forebay, and the spillway and powerhouse are well separated. In addition, the spillway is operated by spilling preferentially from the north shore, that is, as far from the powerhouse as possible. Operations are detailed in Tables 2.12 and 2.13 .

The Dalles tailrace has very complex bathymetry (Figure 2.2). From previous work with 3D numerical models and reduced-scale physical models as well as from prototype velocity measurements, we know the flow structure is very $3 \mathrm{D}$ in some locations. As such, results in the near-project areas should be used with caution.

In the tailrace, the spillwall limits the extent of spill flow influence (Figures 3.5 to 3.8 ). The wide separation of the powerhouse and spillway flows ensures that the downstream extent of hydraulic influence is downstream of the bridge islands. The channel geometry limits the downstream extent, and like in the Bonneville forebay, the extent is greatest at $250 \mathrm{kcfs}$, and much more limited at $450 \mathrm{kcfs}$.

In the forebay, there is little difference in the hydraulic extents between the 250-, 270-, and 450kcfs flows. 


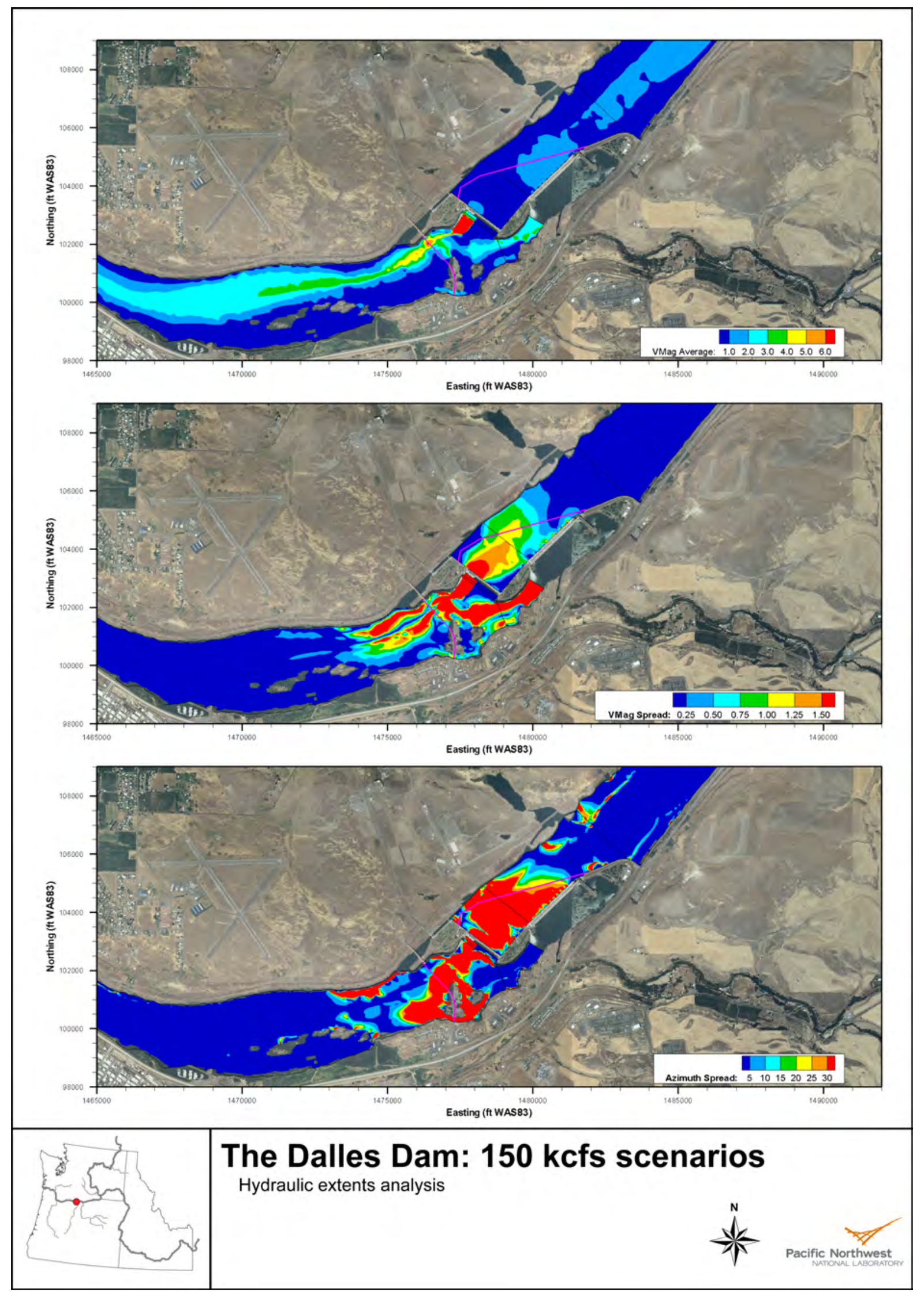

Figure 3.5. The Dalles Project for $150 \mathrm{kcfs}$. Velocities in $\mathrm{ft} / \mathrm{s}$. 


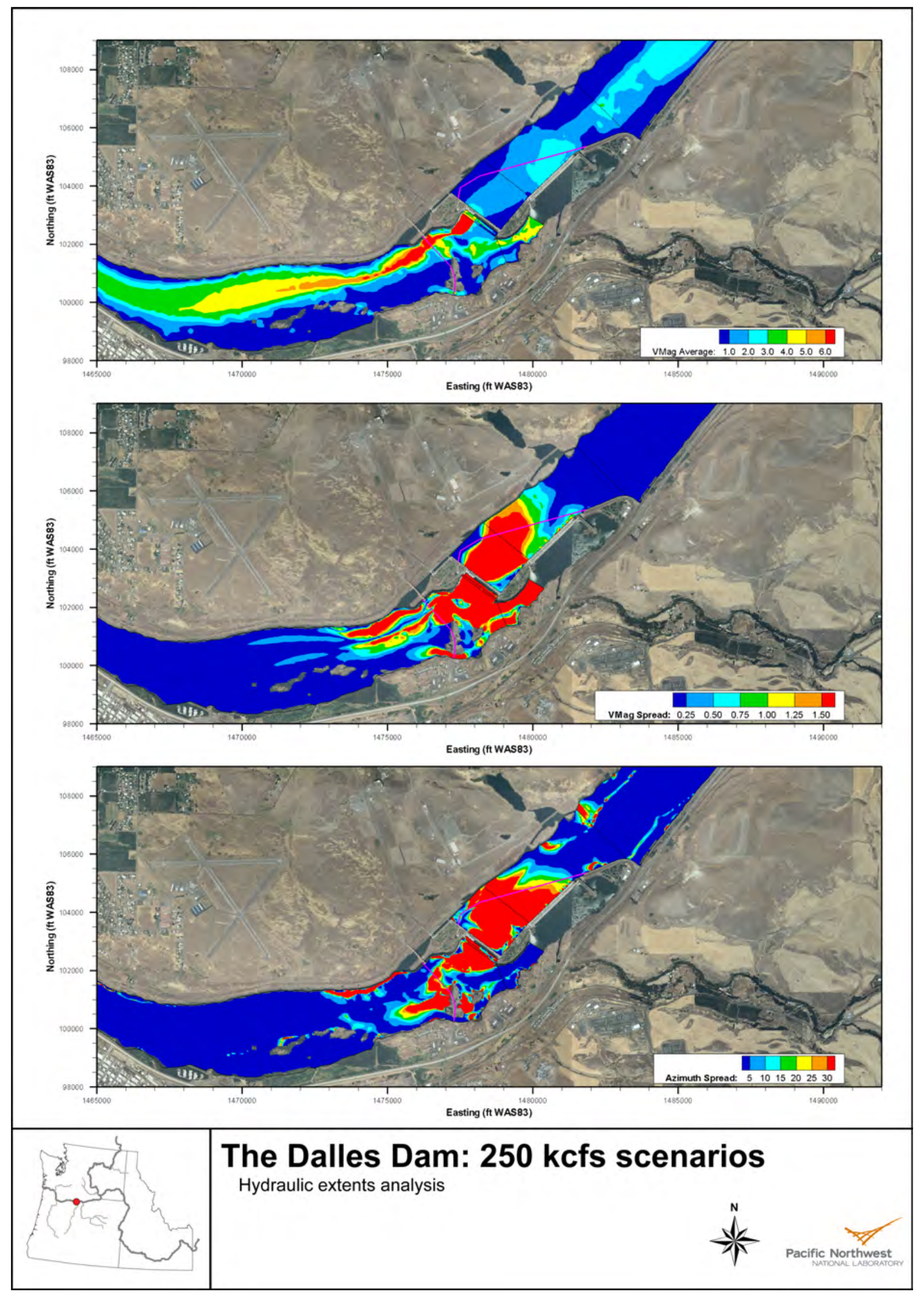

Figure 3.6. The Dalles Project for $250 \mathrm{kcfs}$. Velocities in $\mathrm{ft} / \mathrm{s}$. 


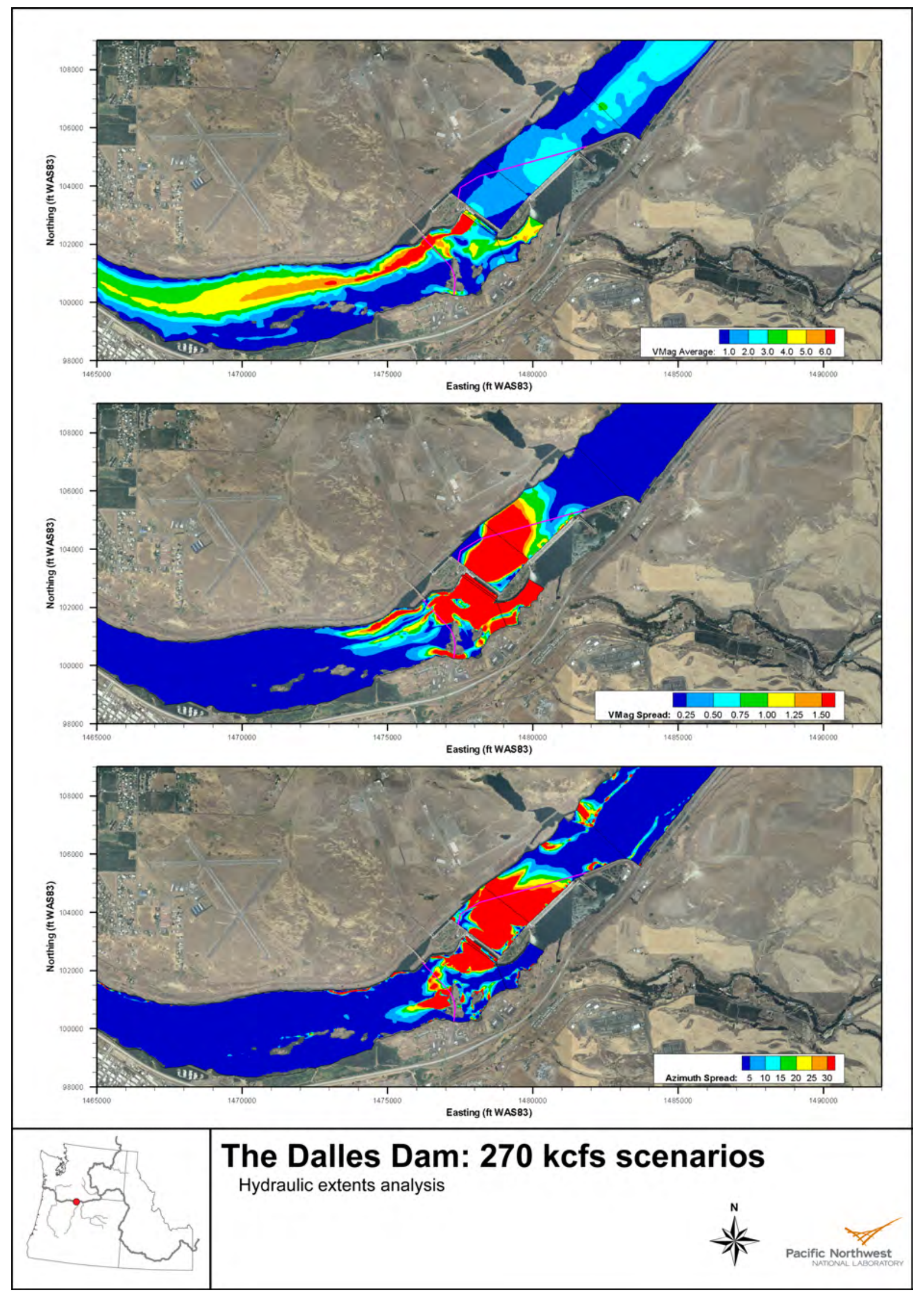

Figure 3.7. The Dalles Project for $270 \mathrm{kcfs}$. Velocities in $\mathrm{ft} / \mathrm{s}$. 


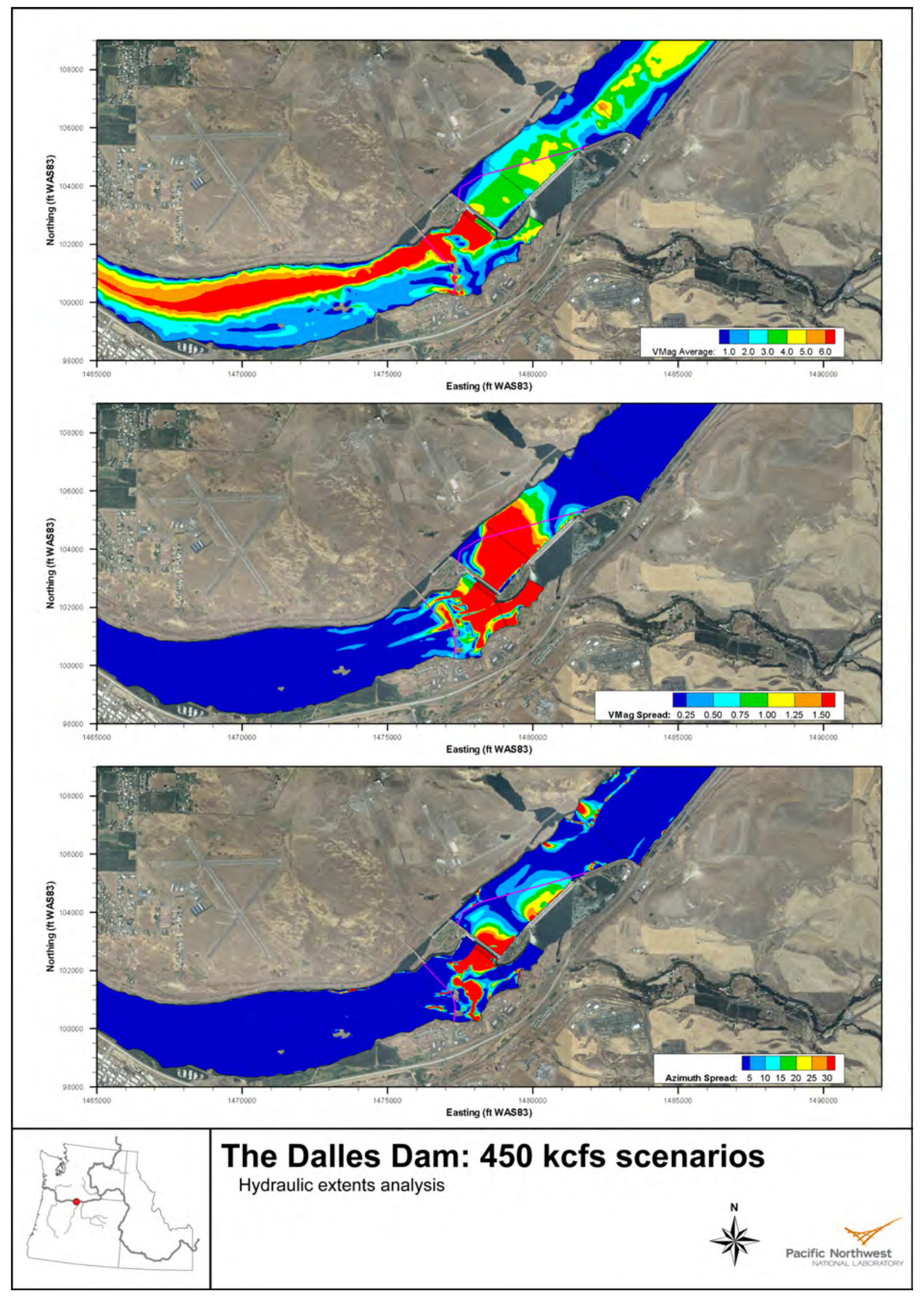

Figure 3.8. The Dalles Project for $450 \mathrm{kcfs}$. Velocities in $\mathrm{ft} / \mathrm{s}$. 


\subsection{John Day Project}

Operations are detailed in Tables 2.14 and 2.15. Figures 3.9 to 3.12 show the results of the MASS2 runs. Downstream of John Day, the channel constricts and a mid-channel island exists. These features limit the extent of the downstream impact of operations at the higher flows. At this project, it is known that both the physical and 2D model under predict the lateral entrainment of flow from the powerhouse and hence the downstream extent of the influence of operations. However, the channel flow constrictions rather than operations will tend to limit the downstream hydraulic extent. Upstream of the dam, the average velocities are much less, and the hydraulic extent of project operations is mostly contained within the BRZ for all flows modeled. 


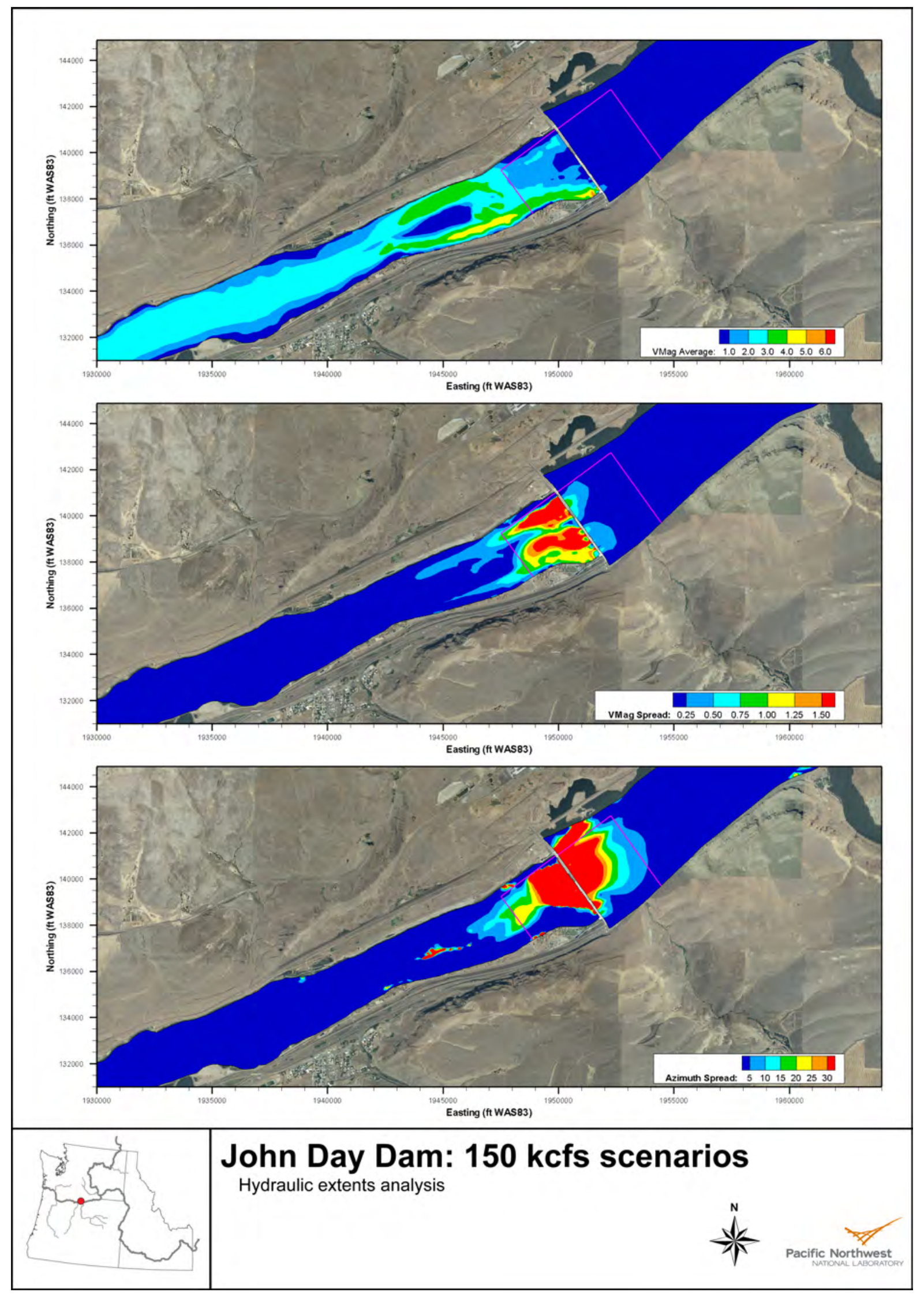

Figure 3.9. John Day Project for $150 \mathrm{kcfs}$. Velocities in $\mathrm{ft} / \mathrm{s}$. 


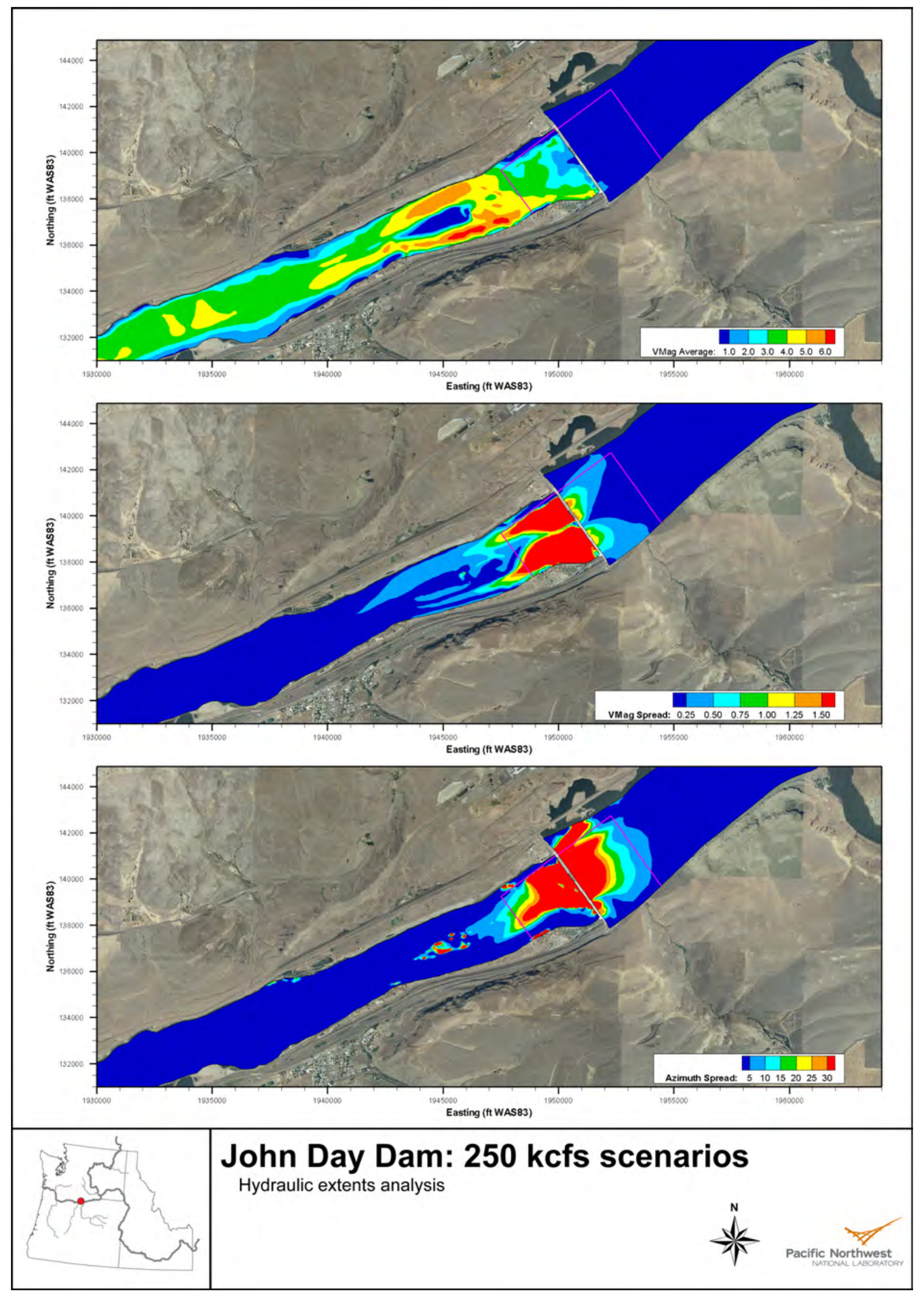

Figure 3.10. John Day Project for $250 \mathrm{kcfs}$. Velocities in ft/s. 


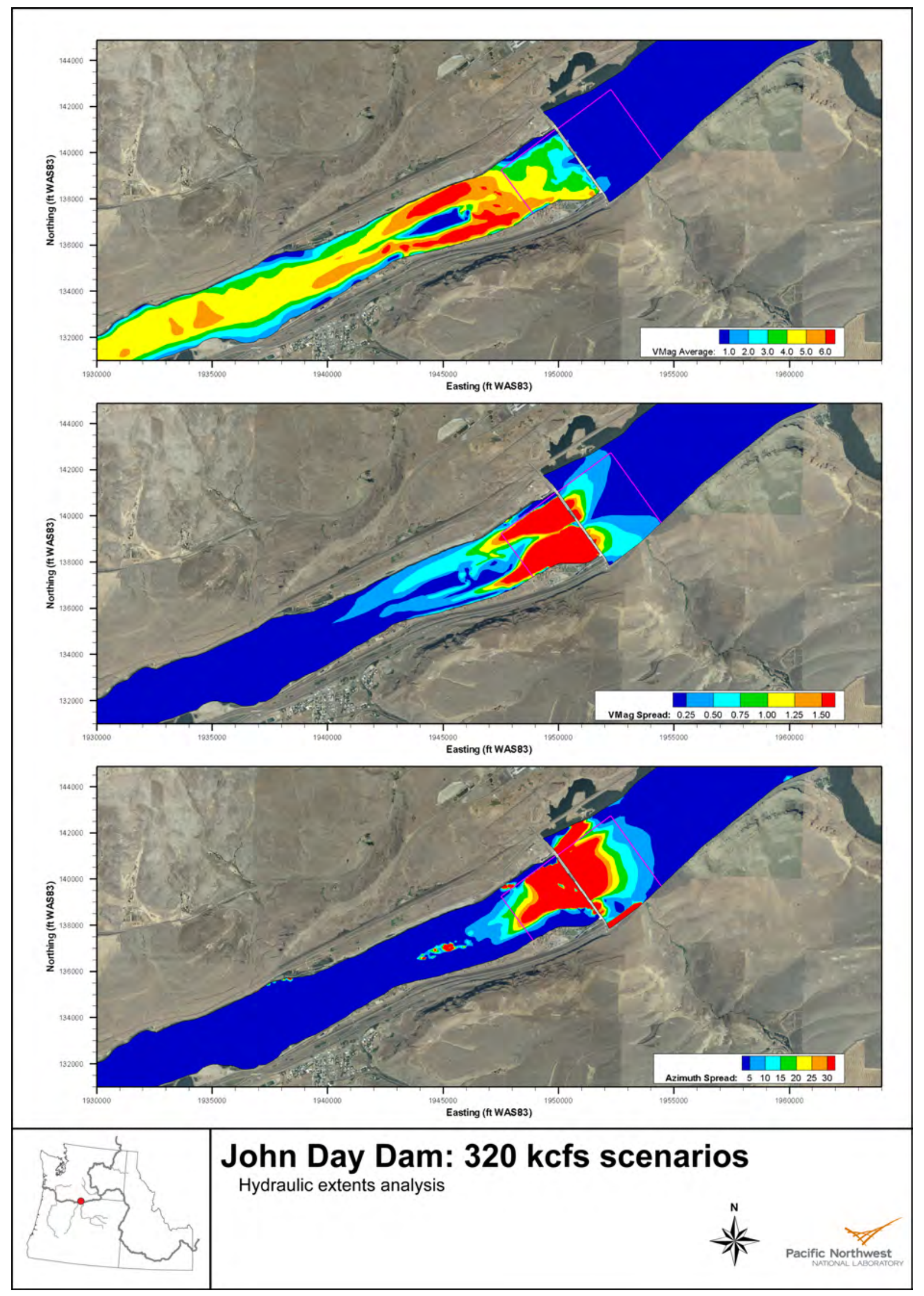

Figure 3.11. John Day Project for $320 \mathrm{kcfs}$. Velocities in ft/s. 


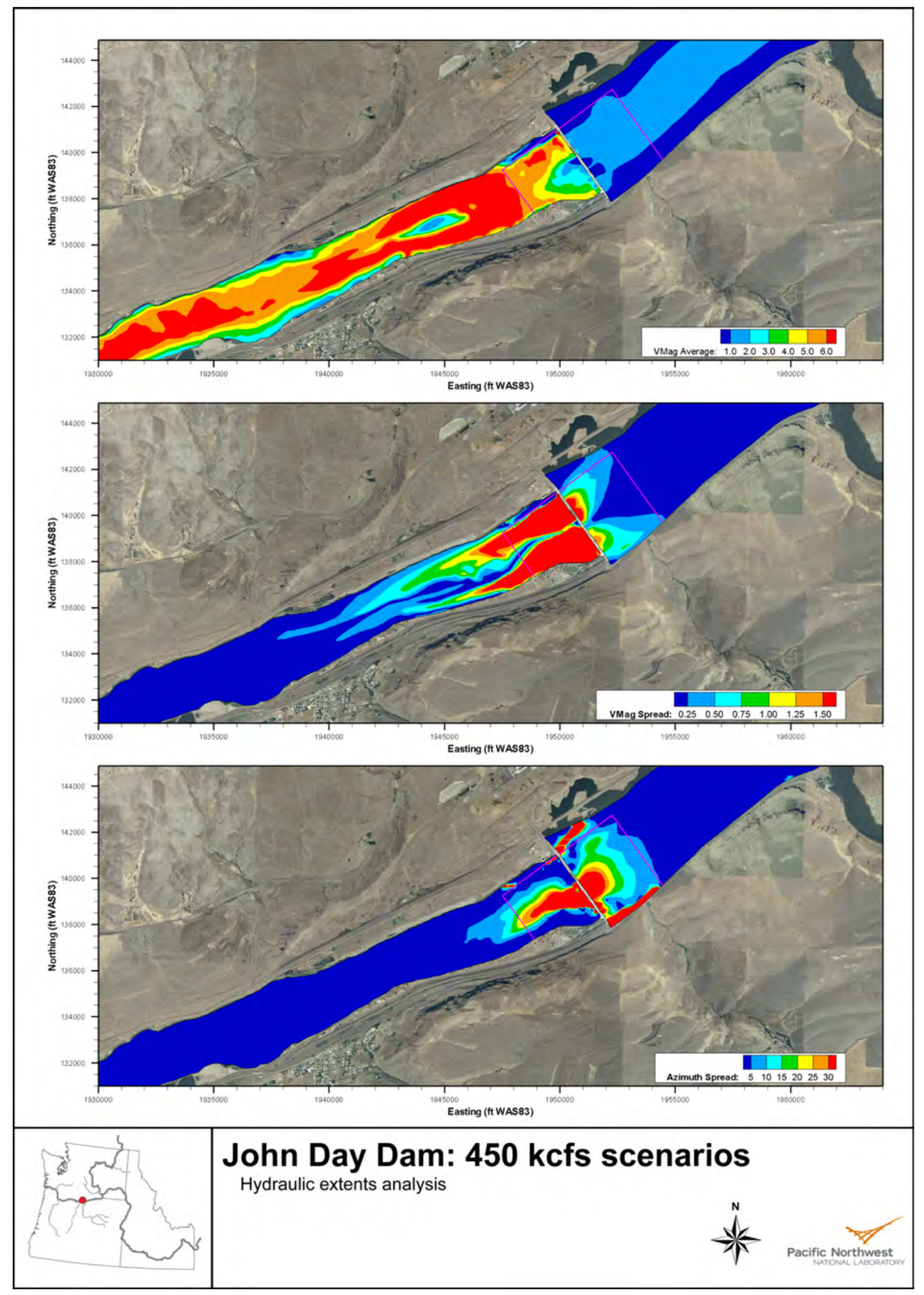

Figure 3.12. John Day Project for $450 \mathrm{kcfs}$. Velocities in ft/s. 


\subsection{McNary Project}

Operations are detailed in Tables 2.16 and 2.17. Figures 3.13 to 3.16 show the results of the MASS2 runs. At McNary, the hydraulic extent is greatest at the mid-range flows. At 350kcfs total river, both the upstream and downstream extent is reduced for both flow-direction and velocity-magnitude differences. For flow direction, the largest downstream extent is at the lowest modeled total river (Figure 3.13), while the greatest downstream extent of differences in velocity magnitude is at 150 and $250 \mathrm{kcfs}$ total river (Figures 3.14 and 3.15). 


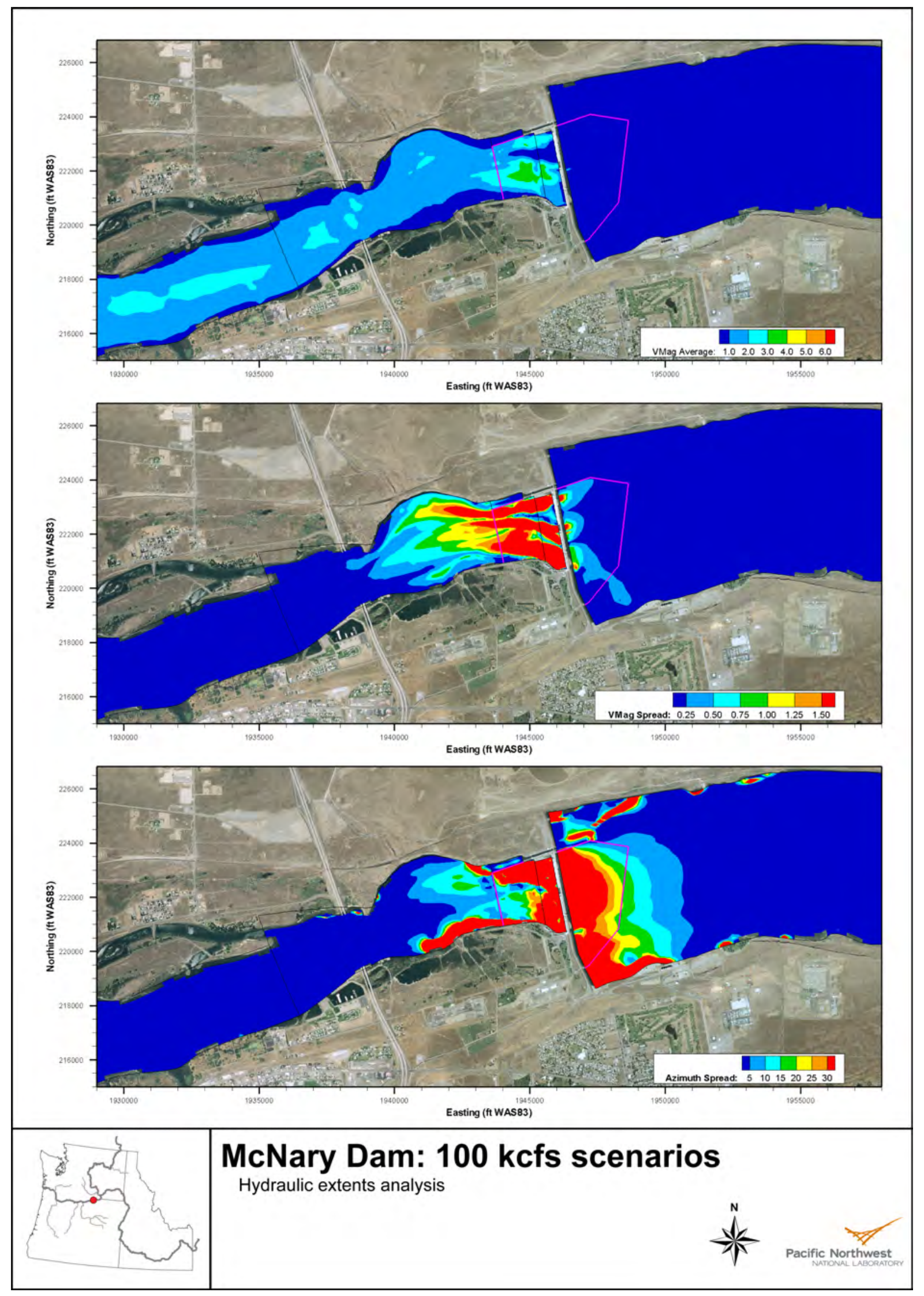

Figure 3.13. McNary Project for $100 \mathrm{kcfs}$. Velocities in $\mathrm{ft} / \mathrm{s}$. 


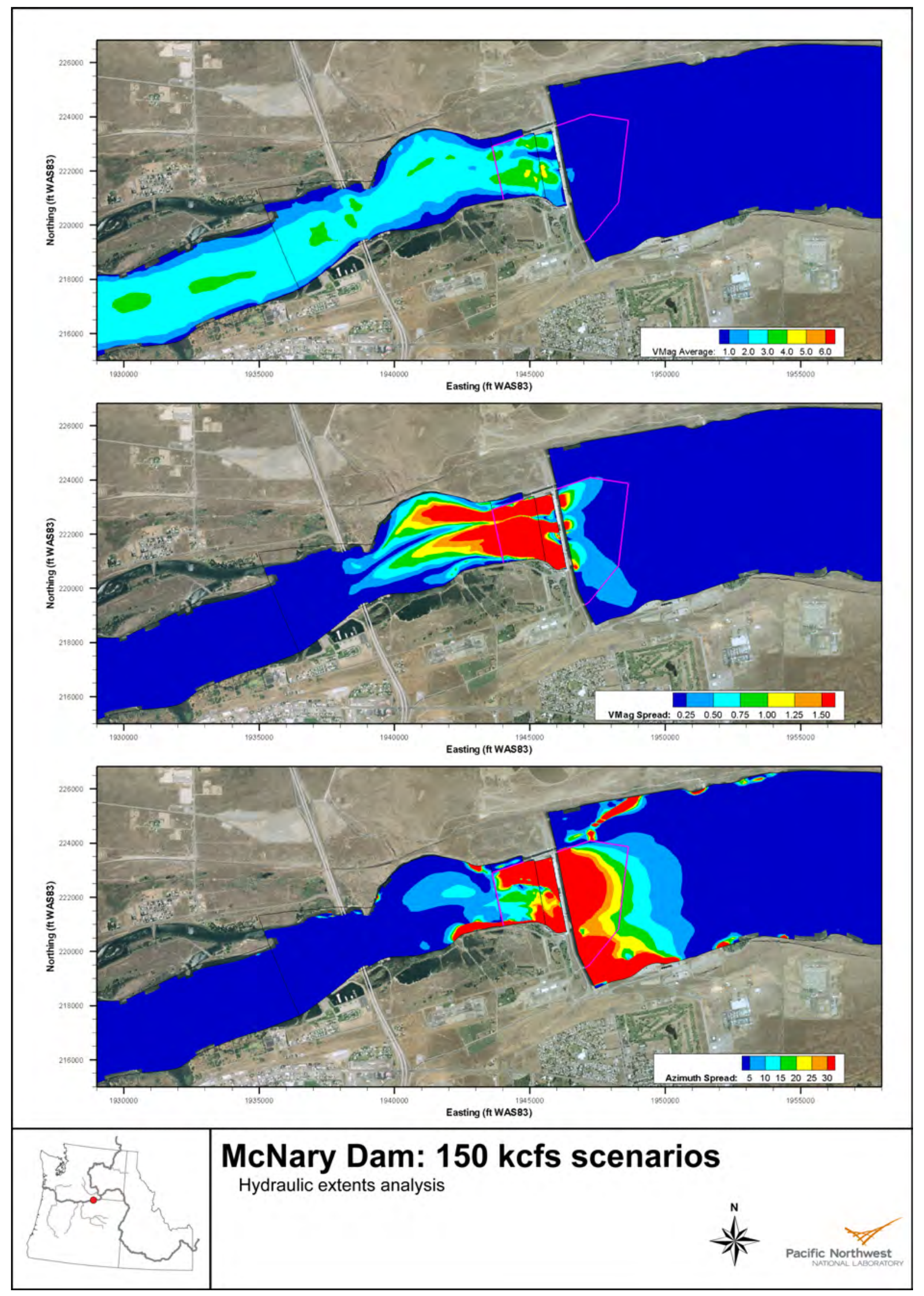

Figure 3.14. McNary Project for $150 \mathrm{kcfs}$. Velocities in $\mathrm{ft} / \mathrm{s}$. 


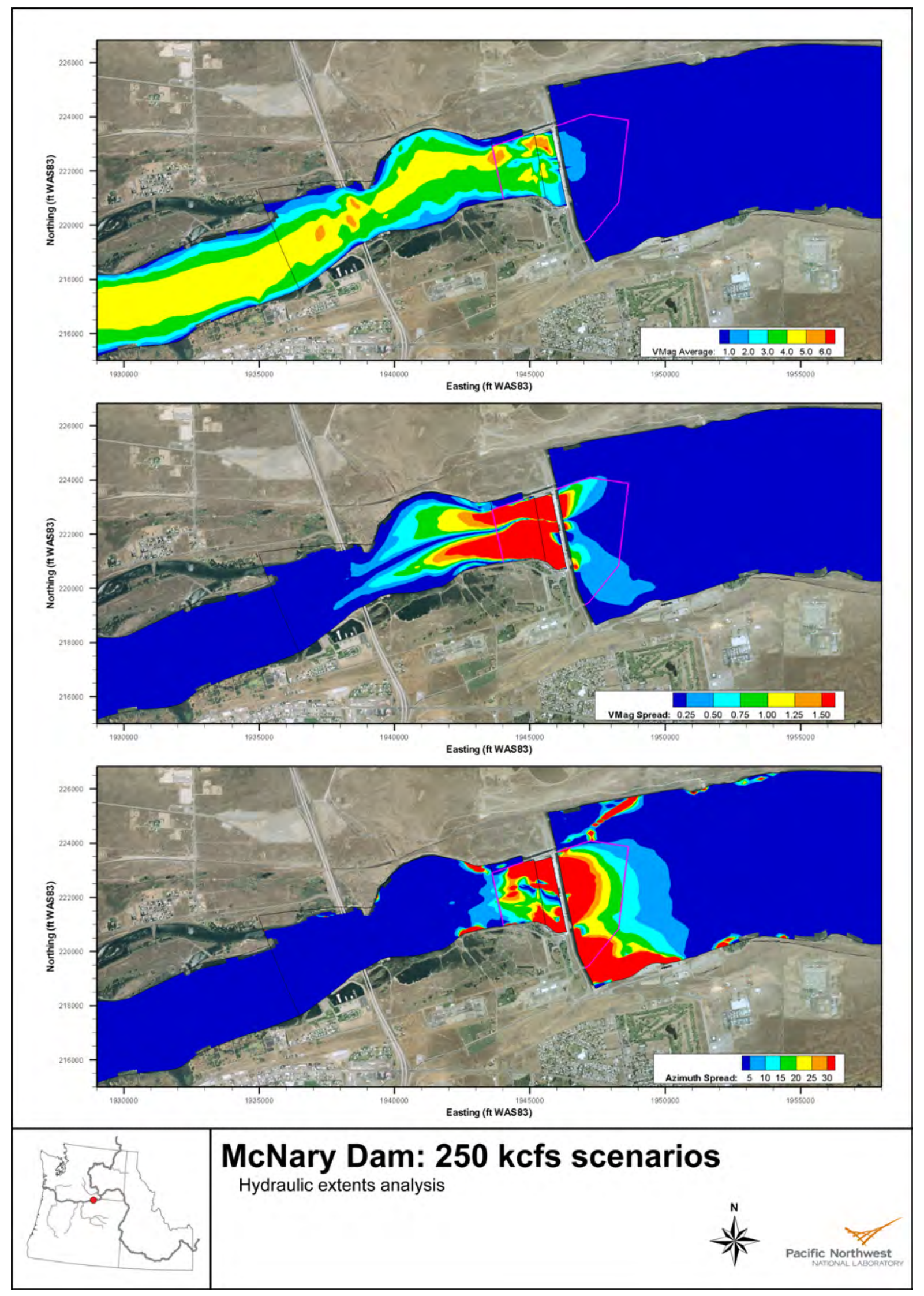

Figure 3.15. McNary Project for $250 \mathrm{kcfs}$. Velocities in $\mathrm{ft} / \mathrm{s}$. 


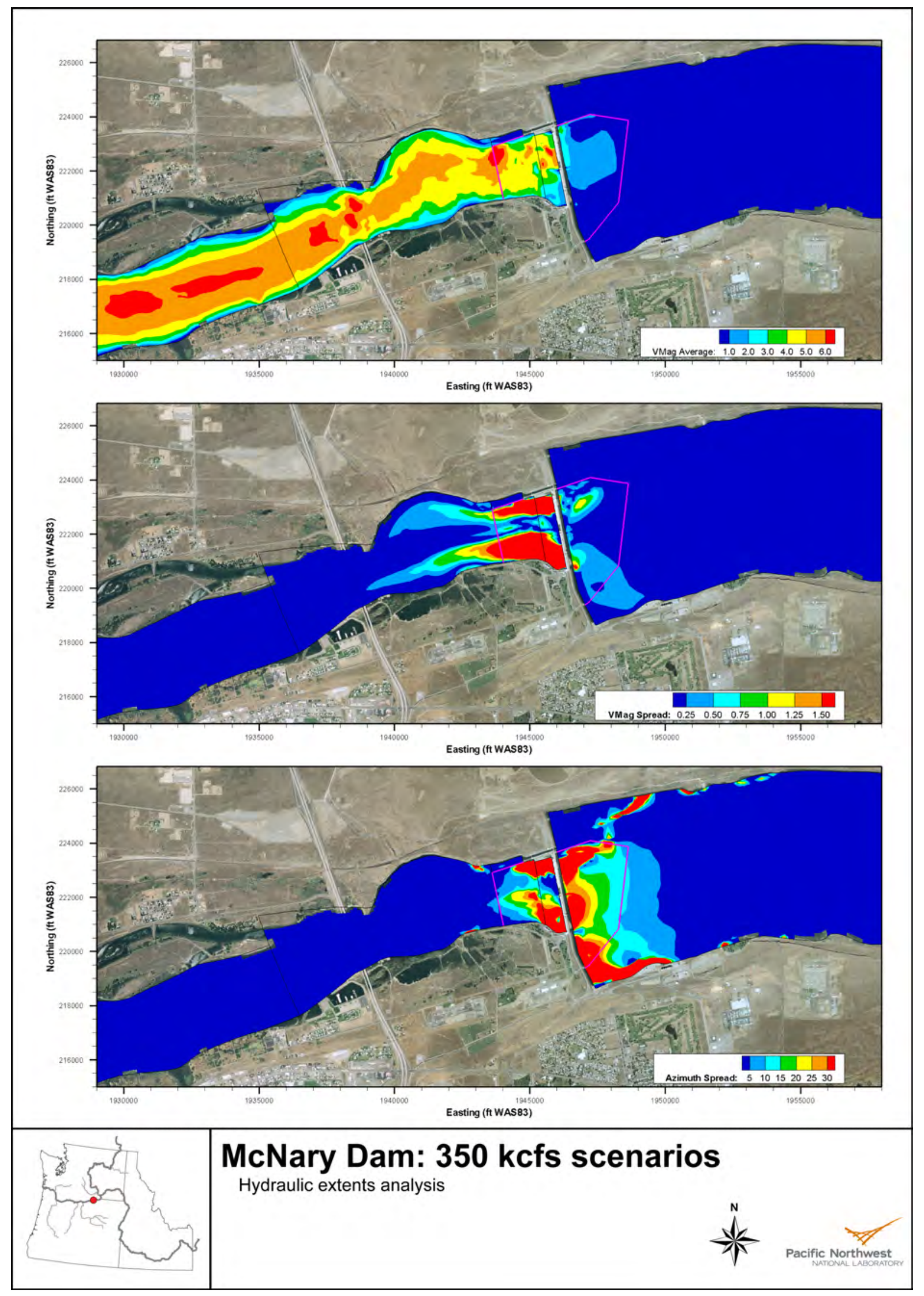

Figure 3.16. McNary Project for $350 \mathrm{kcfs}$. Velocities in $\mathrm{ft} / \mathrm{s}$. 


\subsection{Ice Harbor Project}

Operations are detailed in Tables 2.18 and 2.19. Figures 3.17 to 3.20 show the results of the MASS2 runs. The Snake River flows are much less than the main stem of the Columbia River. The greatest impacts on flow are, for the most part, limited to within the BRZ both upstream and downstream of the project. At the lower flows (19 and $30 \mathrm{kcfs}$, Figures 3.17 and 3.18 , respectively), there is an additional area of large differences in the center of the channel. These are from the flow scenarios that were specified to have the maximum momentum in the center of the river in addition to the powerhouse and spillway priority flow scenarios.

In the forebay, there is little difference in the upstream extent of the difference of flow directions. 


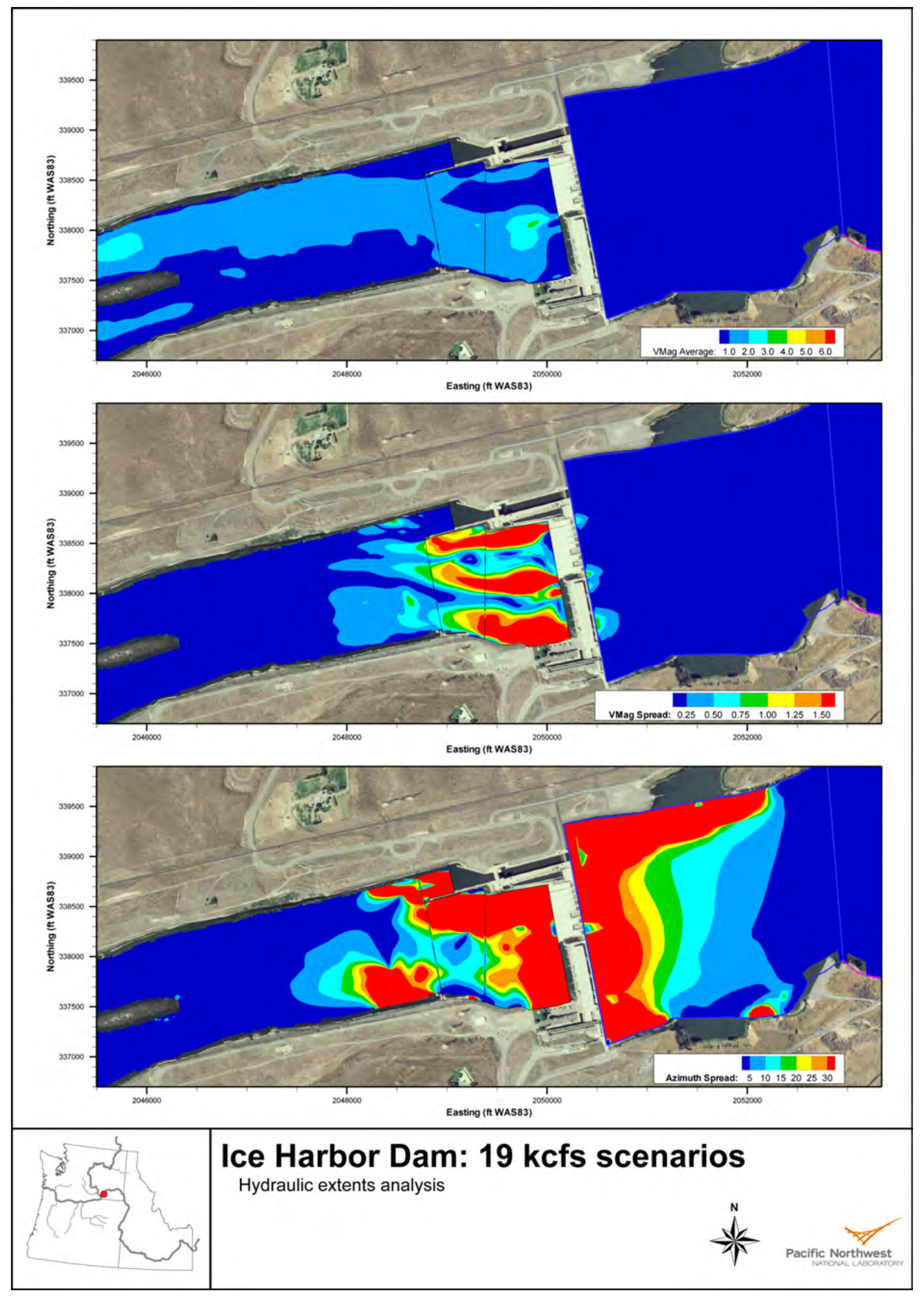

Figure 3.17. Ice Harbor Project for $19 \mathrm{kcfs}$. Velocities in ft/s. 


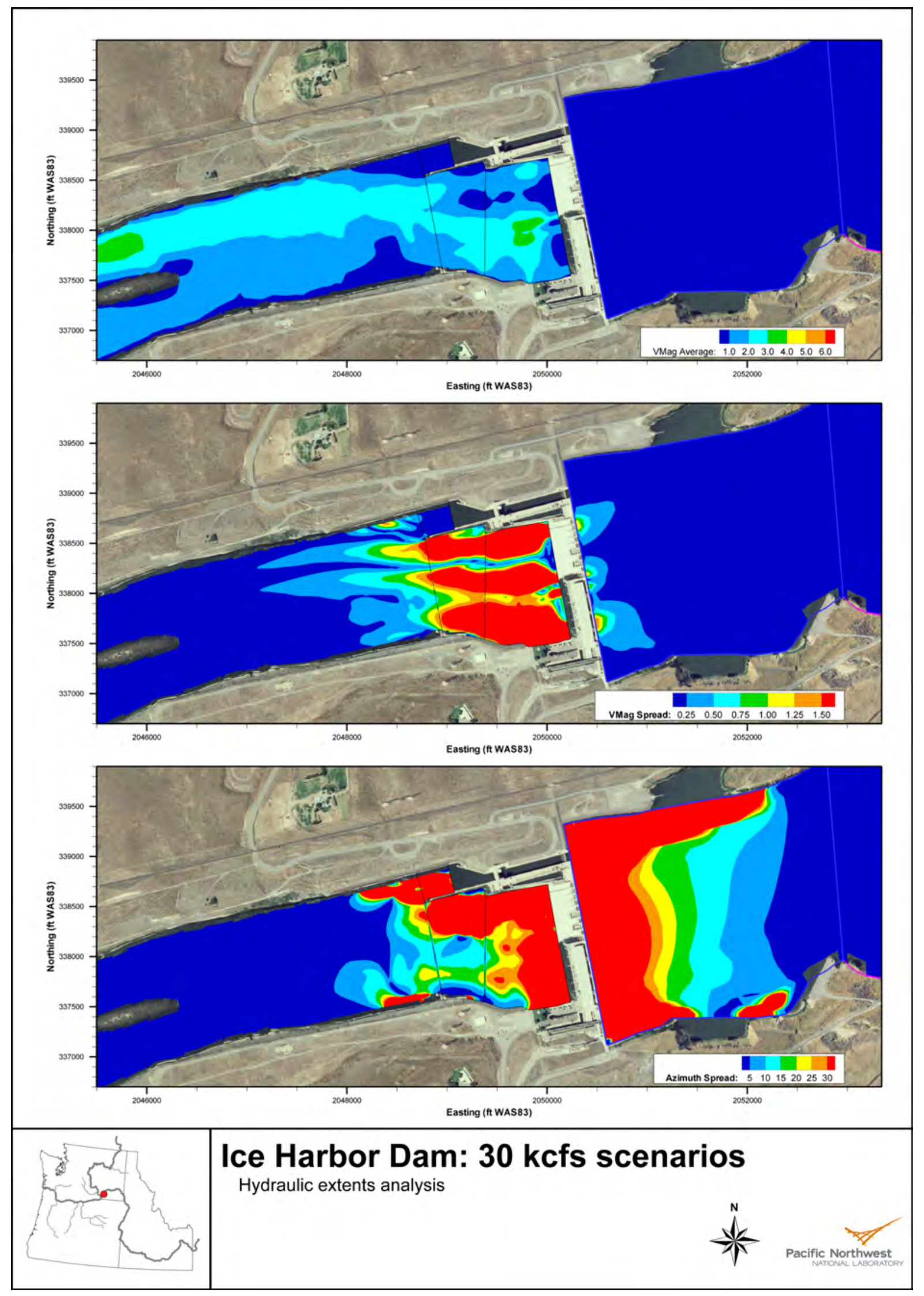

Figure 3.18. Ice Harbor Project for $30 \mathrm{kcfs}$. Velocities in ft/s. 


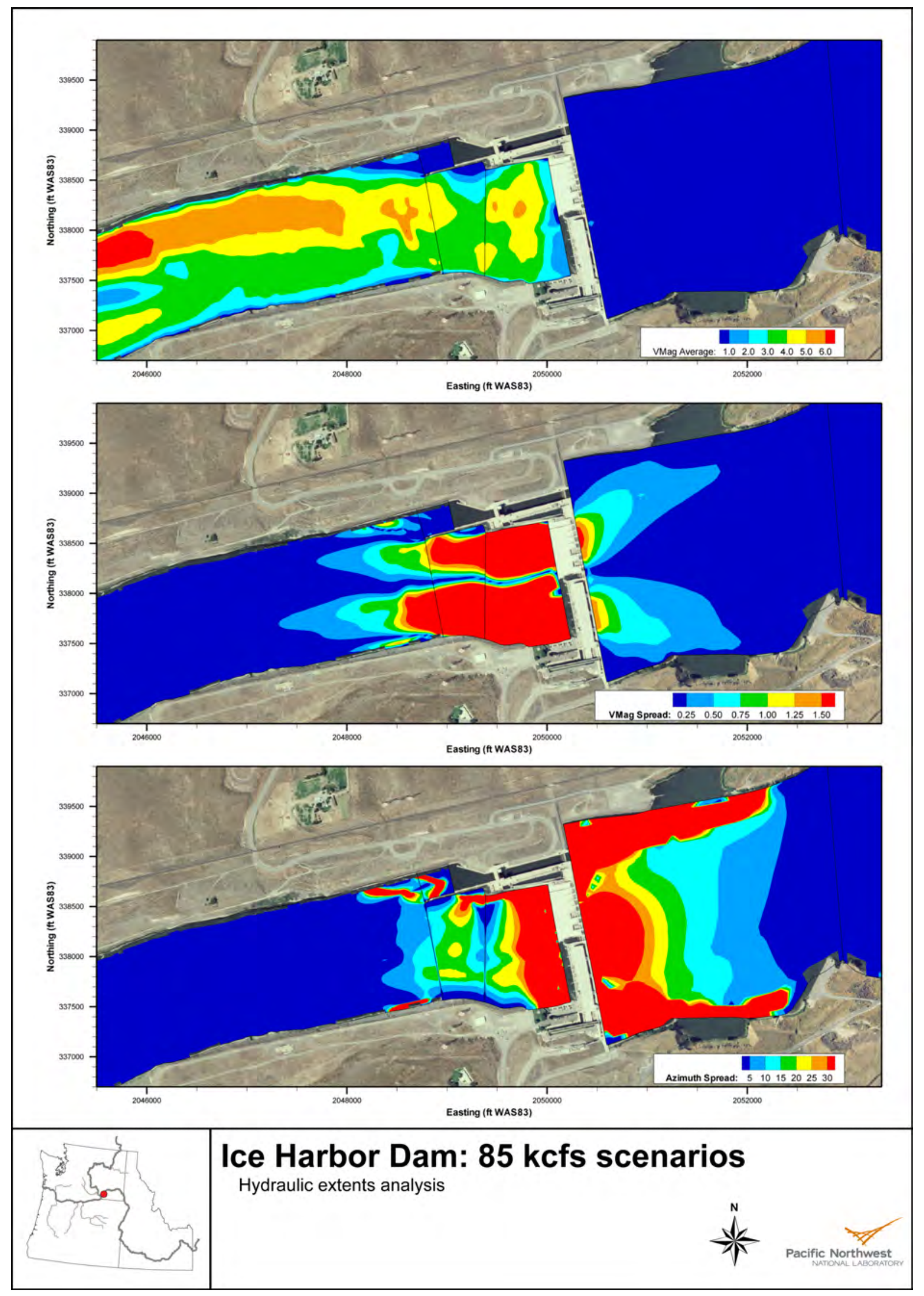

Figure 3.19. Ice Harbor Project for $85 \mathrm{kcfs}$. Velocities in ft/s. 


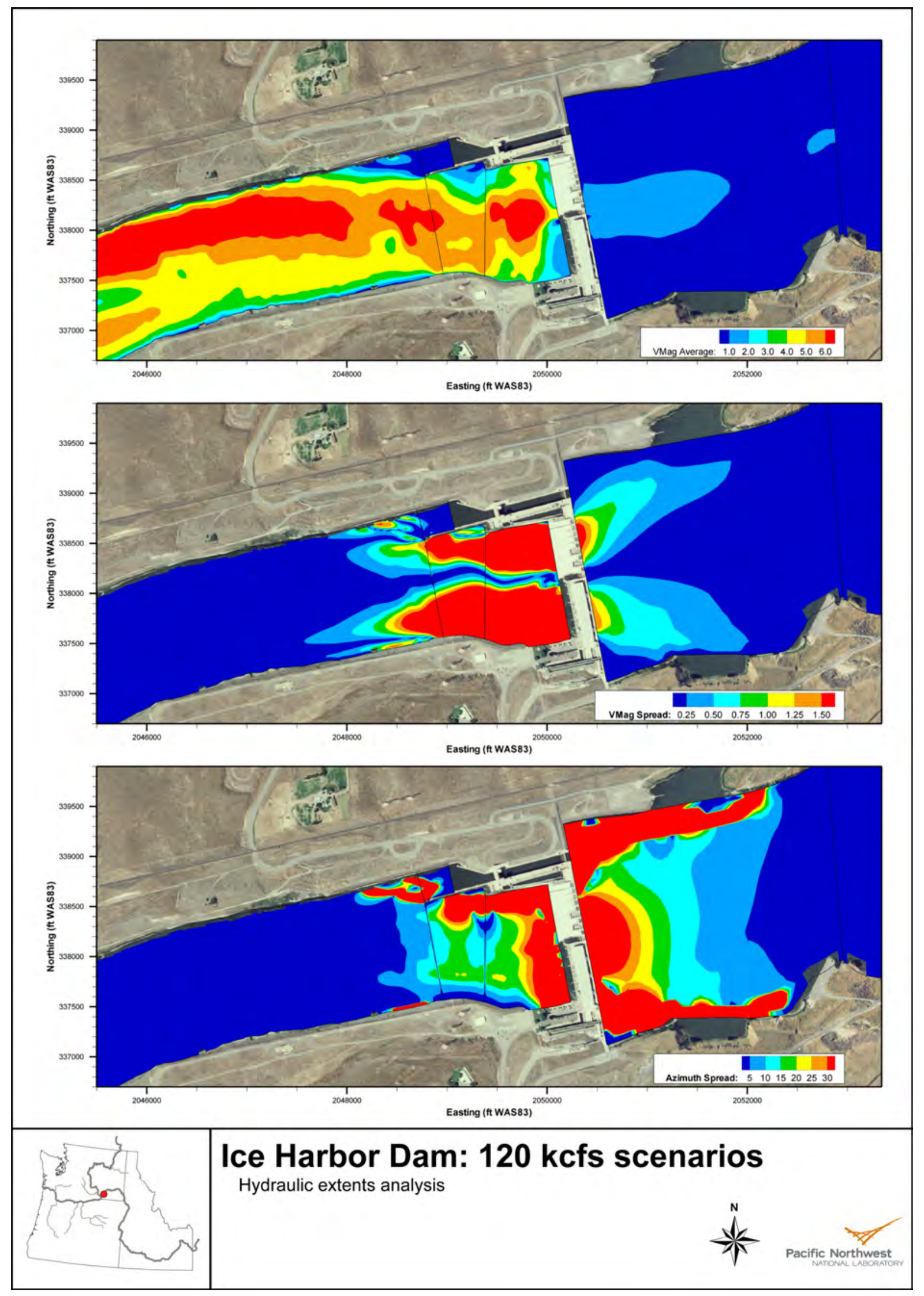

Figure 3.20. Ice Harbor Project for $120 \mathrm{kcfs}$. Velocities in $\mathrm{ft} / \mathrm{s}$. 


\subsection{Lower Monumental Project}

Operations are detailed in Tables 2.20 and 2.21. Figures 3.21 to 3.24 show the results of the MASS2 runs. At Lower Monumental, the downstream extent in the spread of velocity magnitude is largest at $30 \mathrm{kcfs}$ (Figure 3.22). The downstream hydraulic extent is probably reduced by the slight channel constriction. In the forebay, the upstream extent of spread in velocity magnitude and flow direction increases with total river flow; however, at $120 \mathrm{kcfs}$ both extents are reduced. 


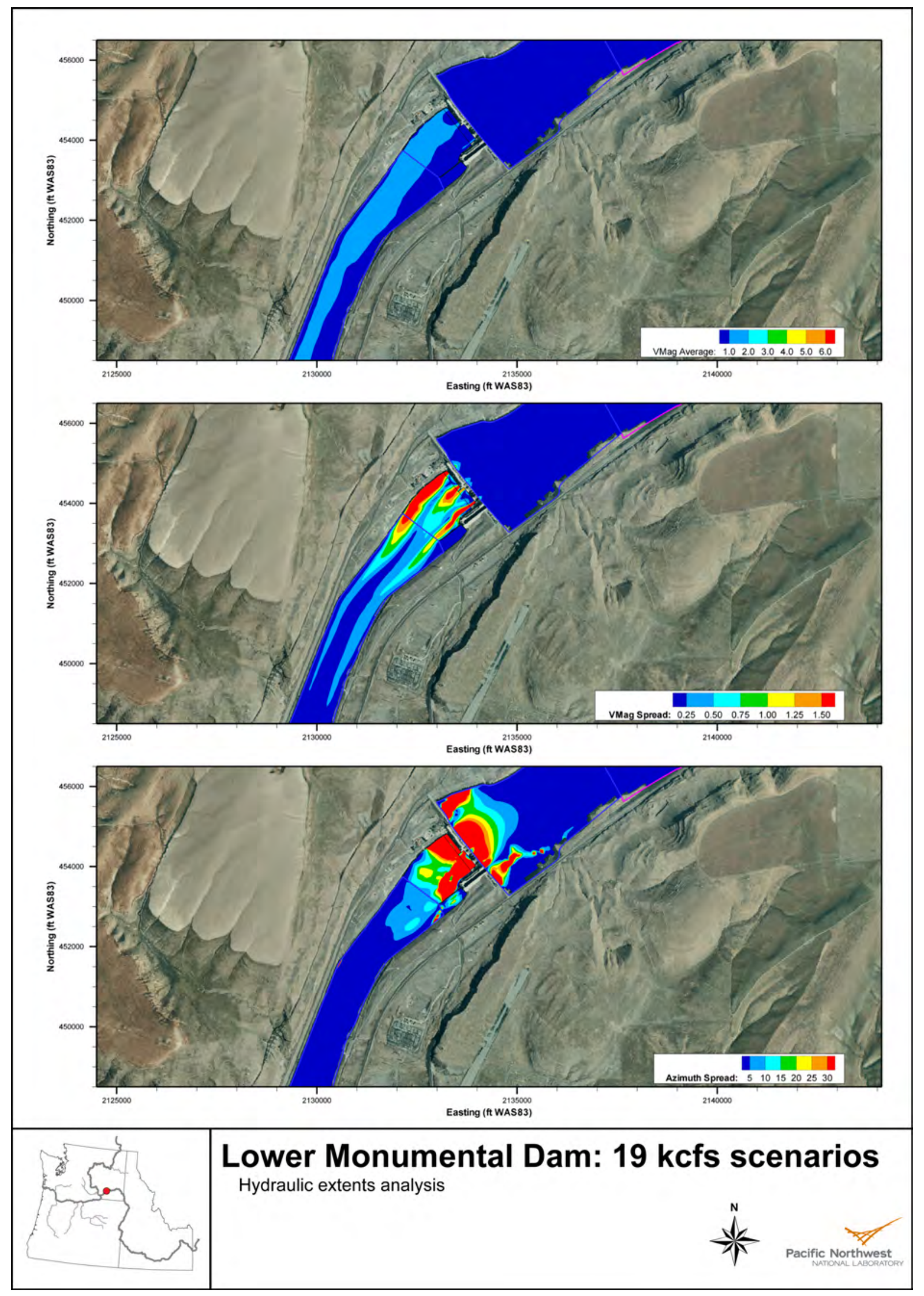

Figure 3.21. Lower Monumental Project for $19 \mathrm{kcfs}$. Velocities in $\mathrm{ft} / \mathrm{s}$. 


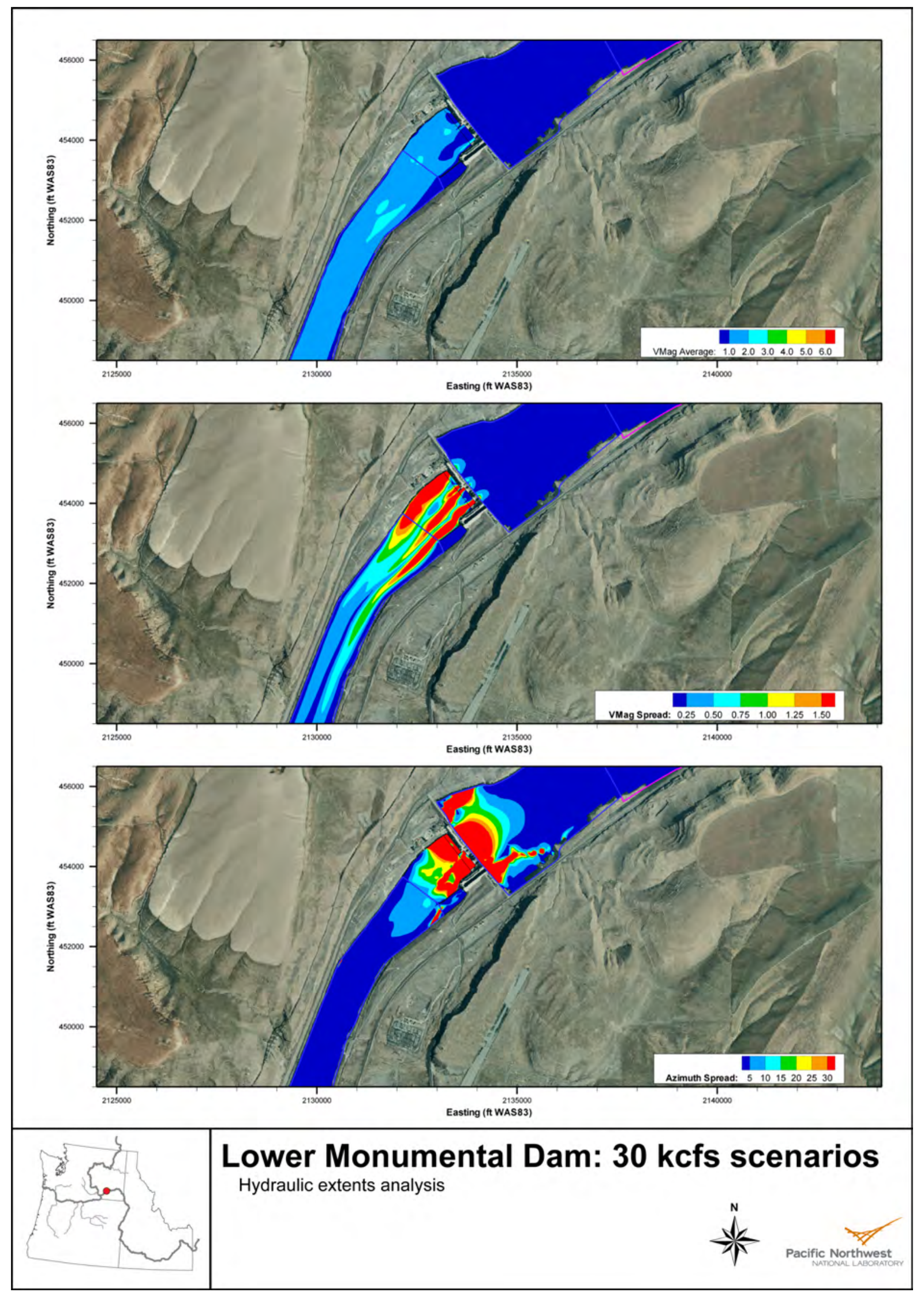

Figure 3.22. Lower Monumental Project for $30 \mathrm{kcfs}$. Velocities in $\mathrm{ft} / \mathrm{s}$. 


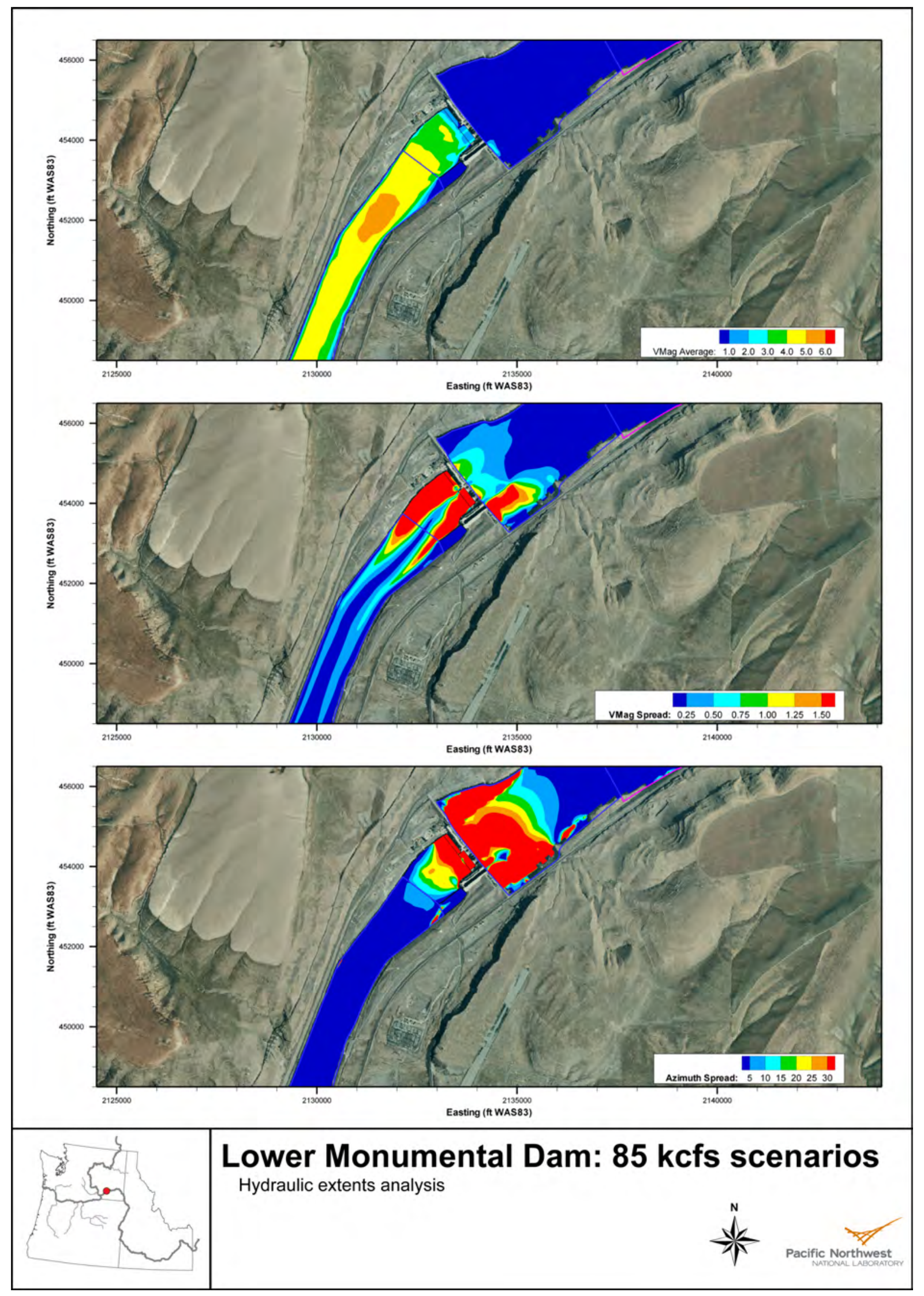

Figure 3.23. Lower Monumental Project for $85 \mathrm{kcfs}$. Velocities in ft/s. 


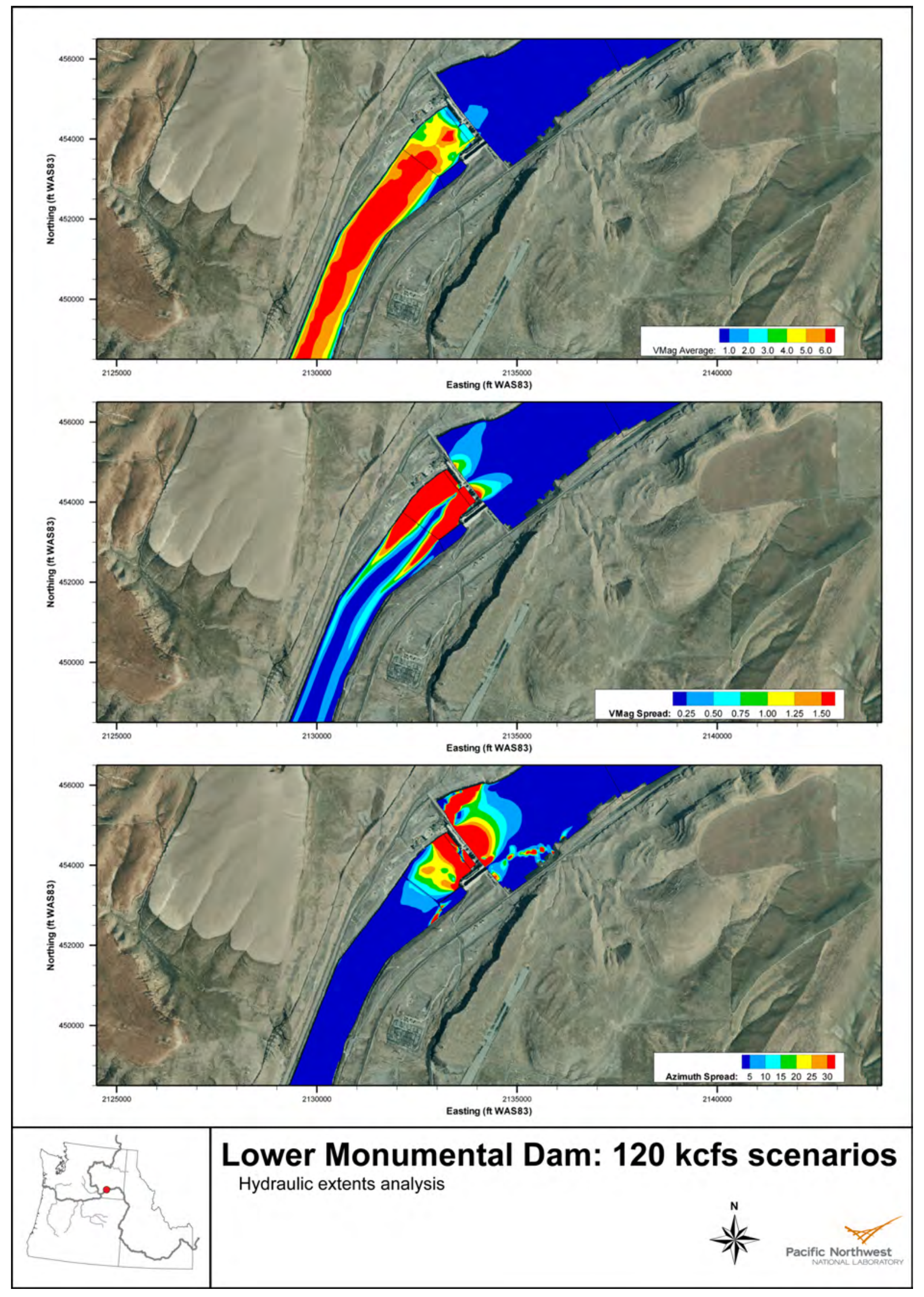

Figure 3.24. Lower Monumental Project for $120 \mathrm{kcfs}$. Velocities in ft/s. 


\subsection{Little Goose Project}

Operations are detailed in Tables 2.22 and 2.23. Figures 3.25 to 3.28 show the results of the MASS2 runs. At Little Goose, the largest downstream hydraulic extent is at $30 \mathrm{kcfs}$ (Figure 3.26). There is a flow constriction downstream of the project that reduces the hydraulic extent at the higher flows. In the forebay, the upstream extent of the spread in velocity magnitude increases with increasing flow volume. However, the magnitude and extent of the differences in flow direction are very similar for all river flows. 


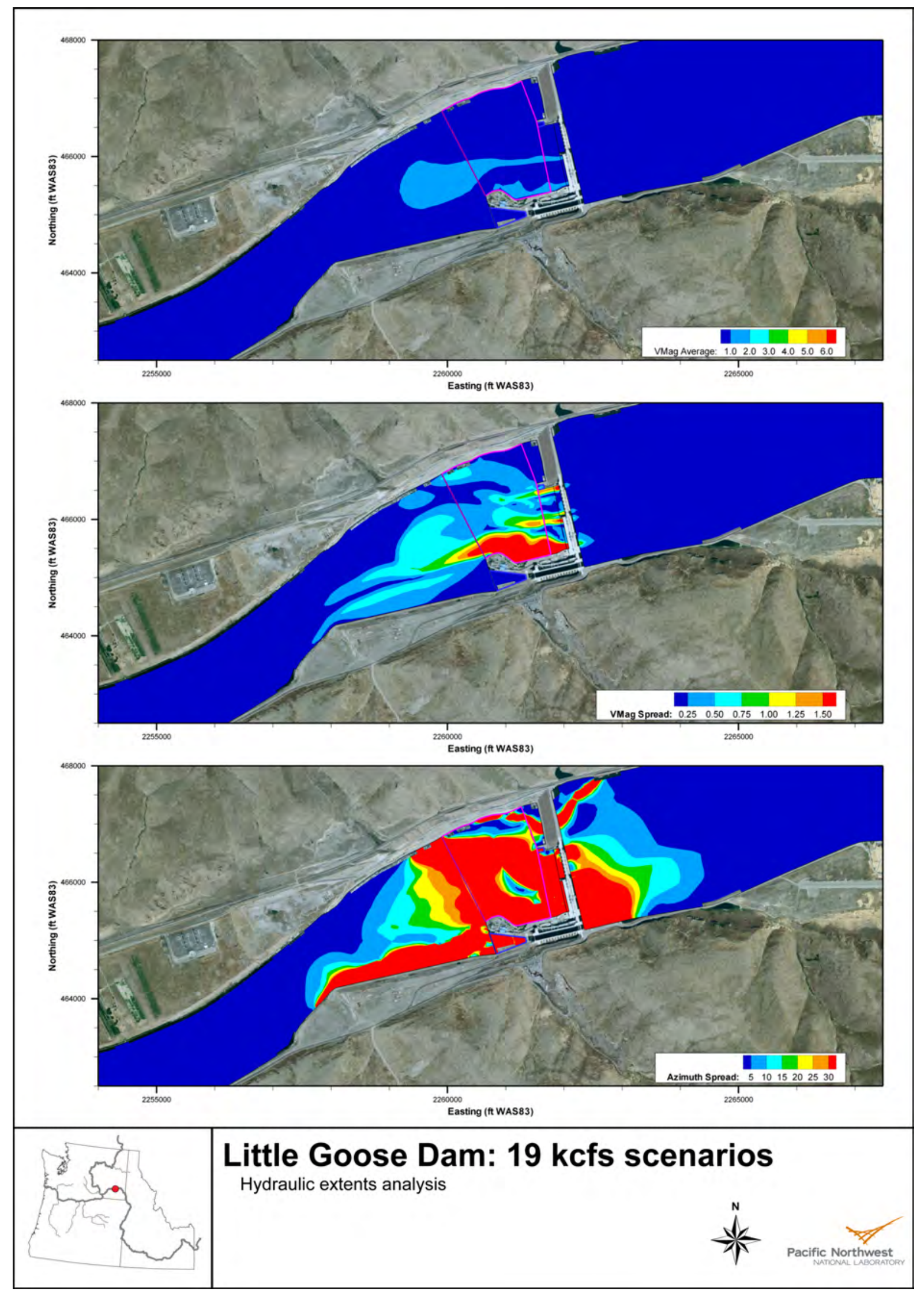

Figure 3.25. Little Goose Project for $19 \mathrm{kcfs}$. Velocities in ft/s. 


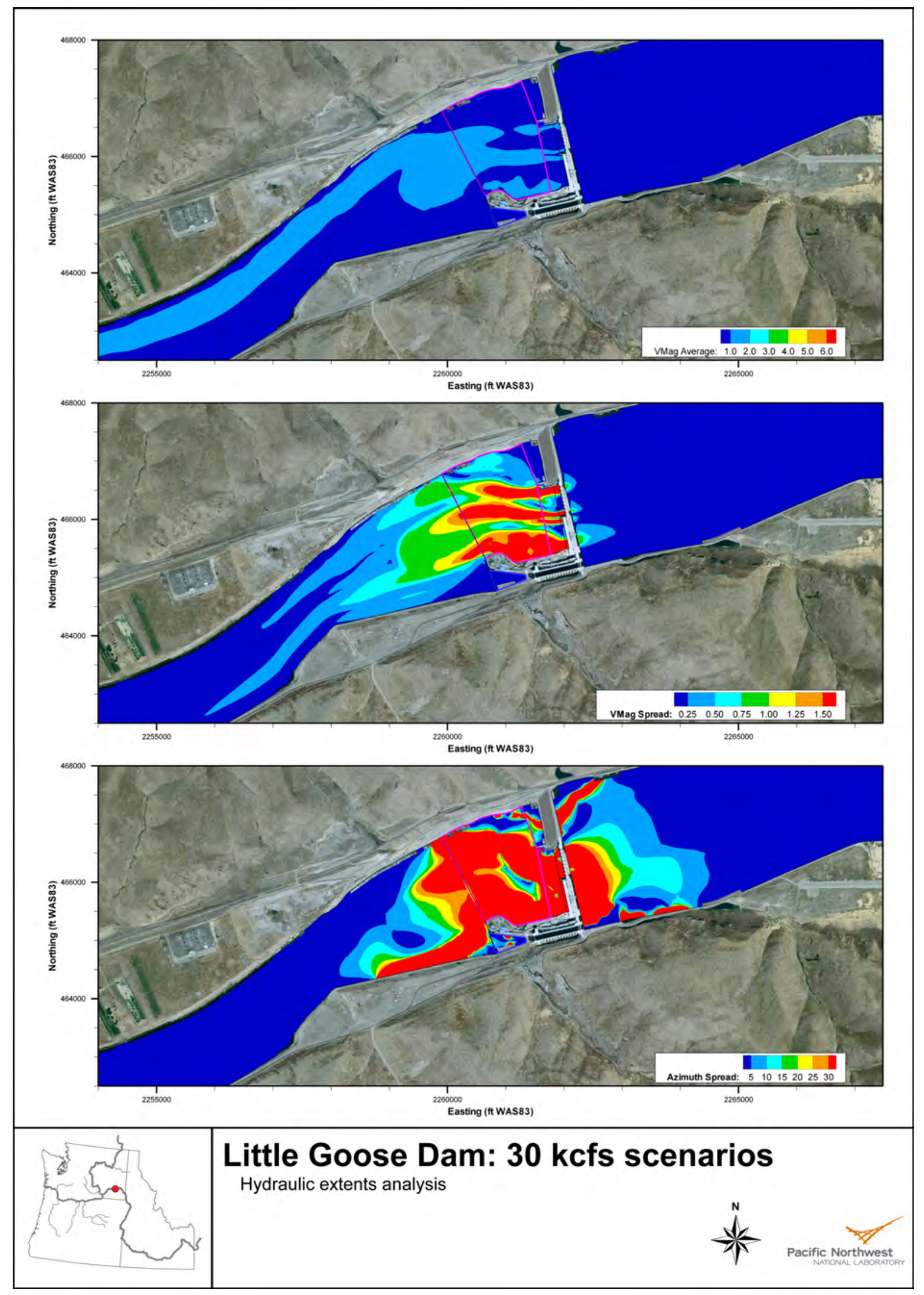

Figure 3.26. Little Goose Project for $30 \mathrm{kcfs}$. Velocities in ft/s. 


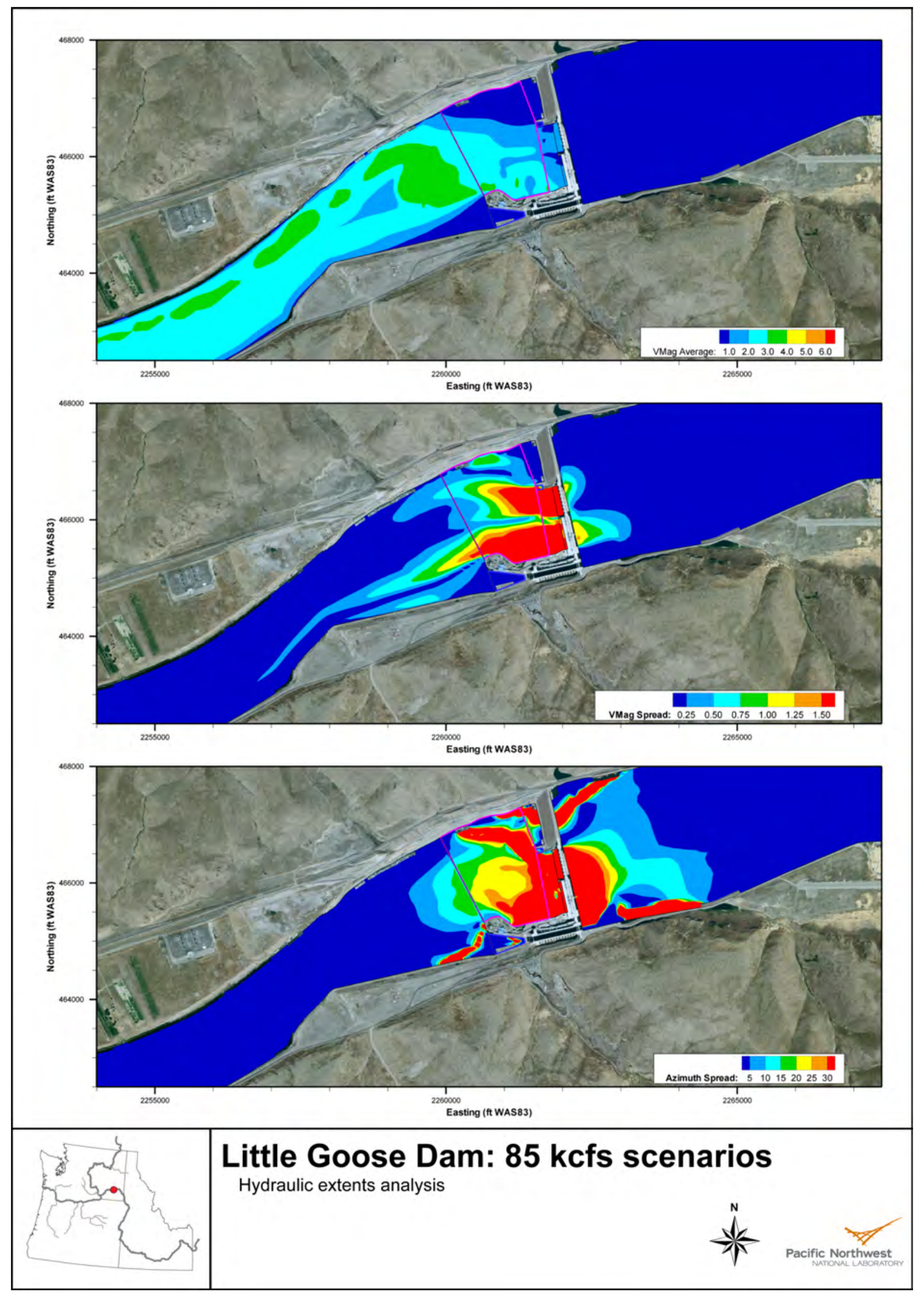

Figure 3.27. Little Goose Project for 85 kcfs. Velocities in ft/s. 


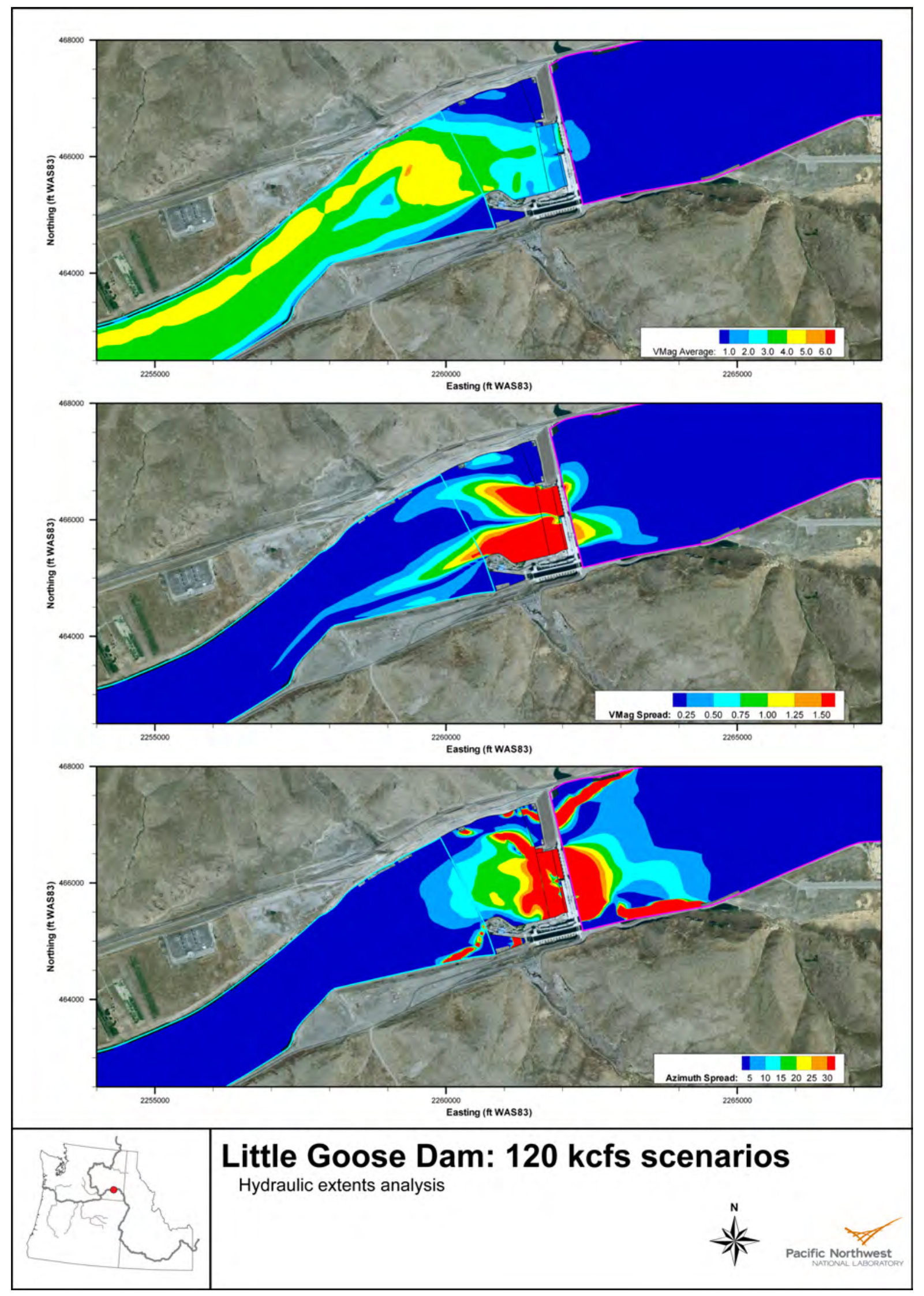

Figure 3.28. Little Goose Project for $120 \mathrm{kcfs}$. Velocities in ft/s. 


\subsection{Lower Granite Project}

Operations are detailed in Tables 2.24 and 2.25. Figures 3.29 to 3.32 show the results of the MASS2 runs. In the tailrace, the downstream hydraulic extent of velocity magnitude differences is very similar for all flows. For flow direction, however, the greatest downstream impact is at the lowest flows with the least extent at the largest total river flow. In the forebay, the upstream hydraulic extent is limited. 


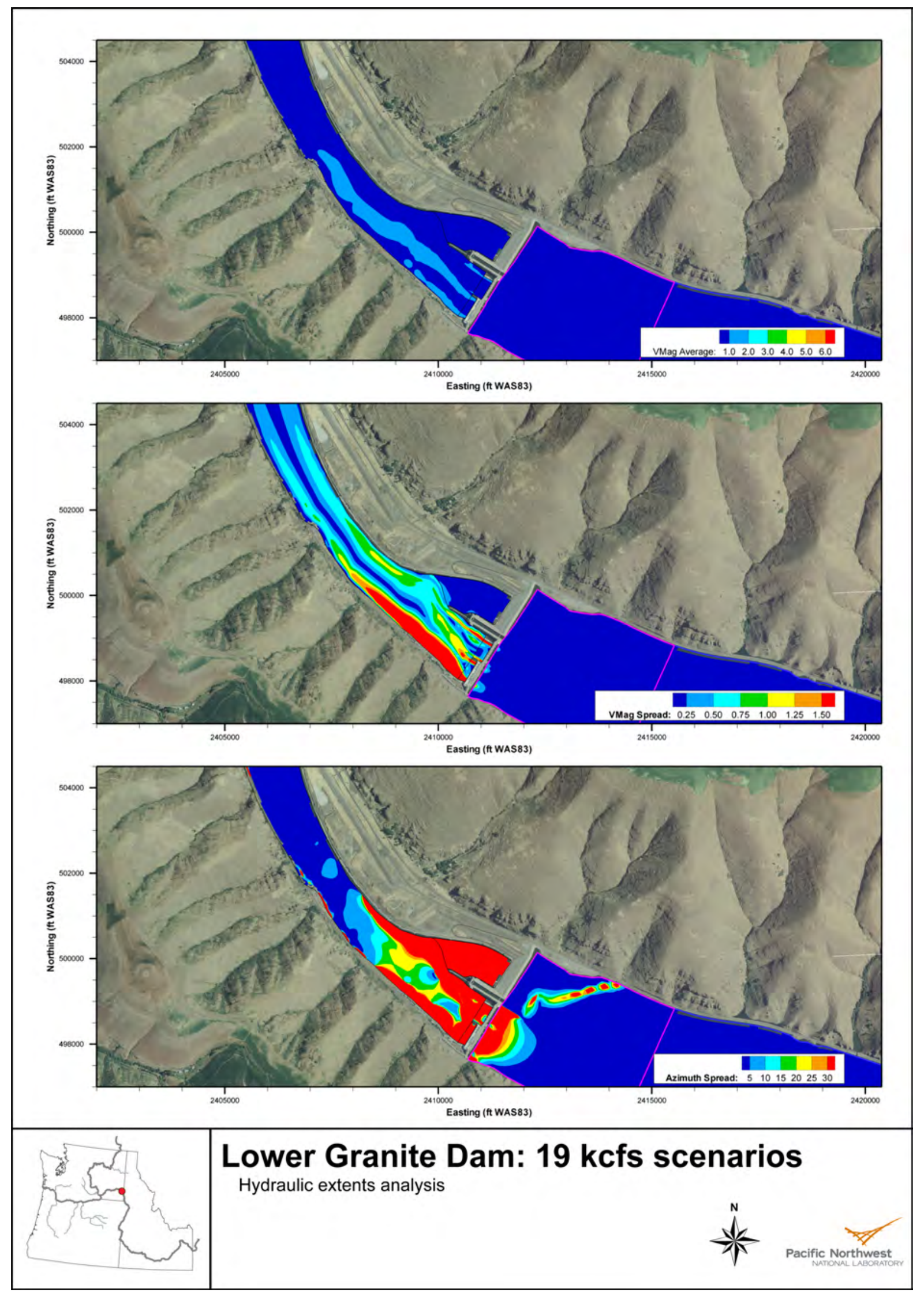

Figure 3.29. Lower Granite Project for $19 \mathrm{kcfs}$. Velocities in $\mathrm{ft} / \mathrm{s}$. 


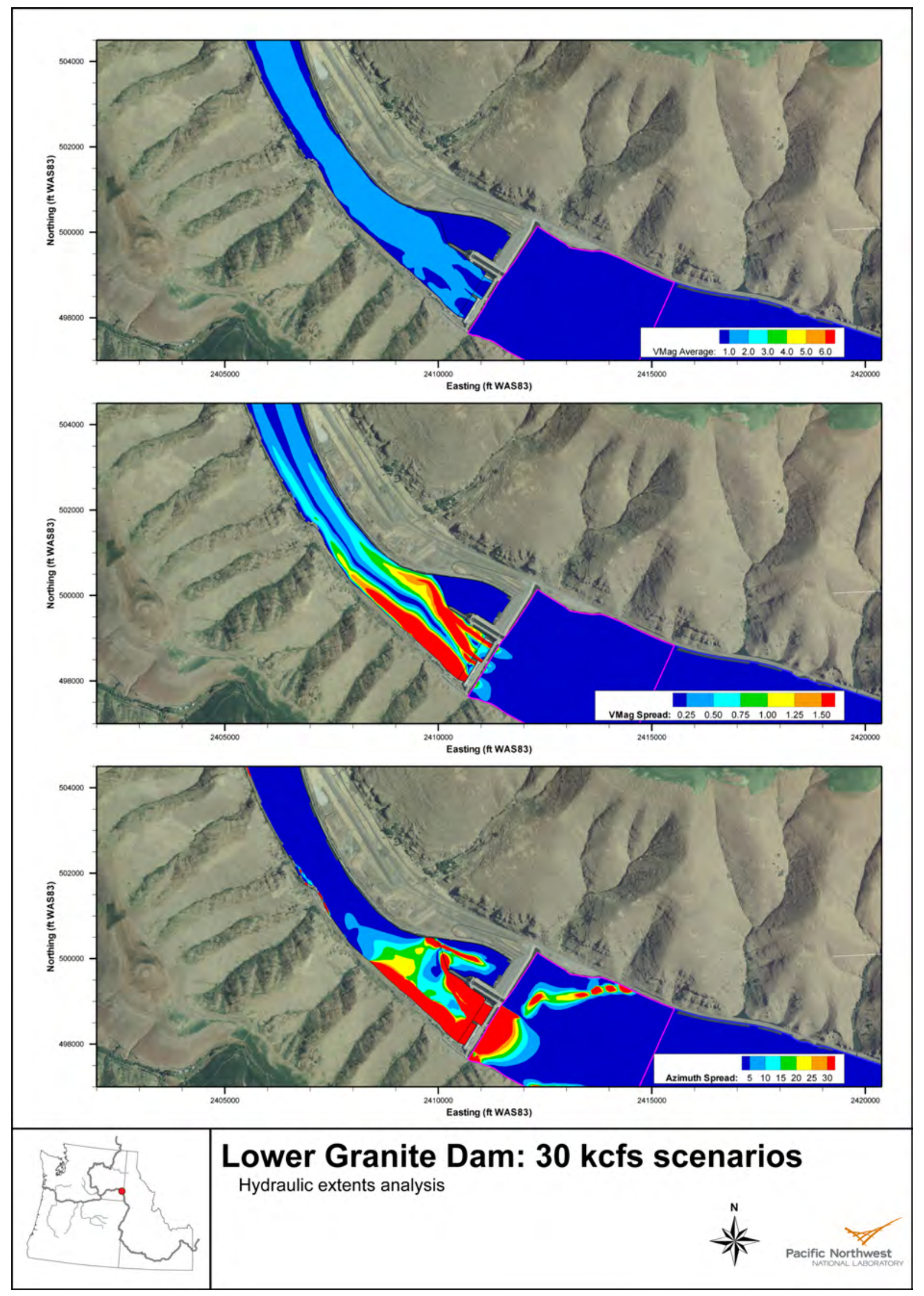

Figure 3.30. Lower Granite Project for $30 \mathrm{kcfs}$. Velocities in $\mathrm{ft} / \mathrm{s}$. 


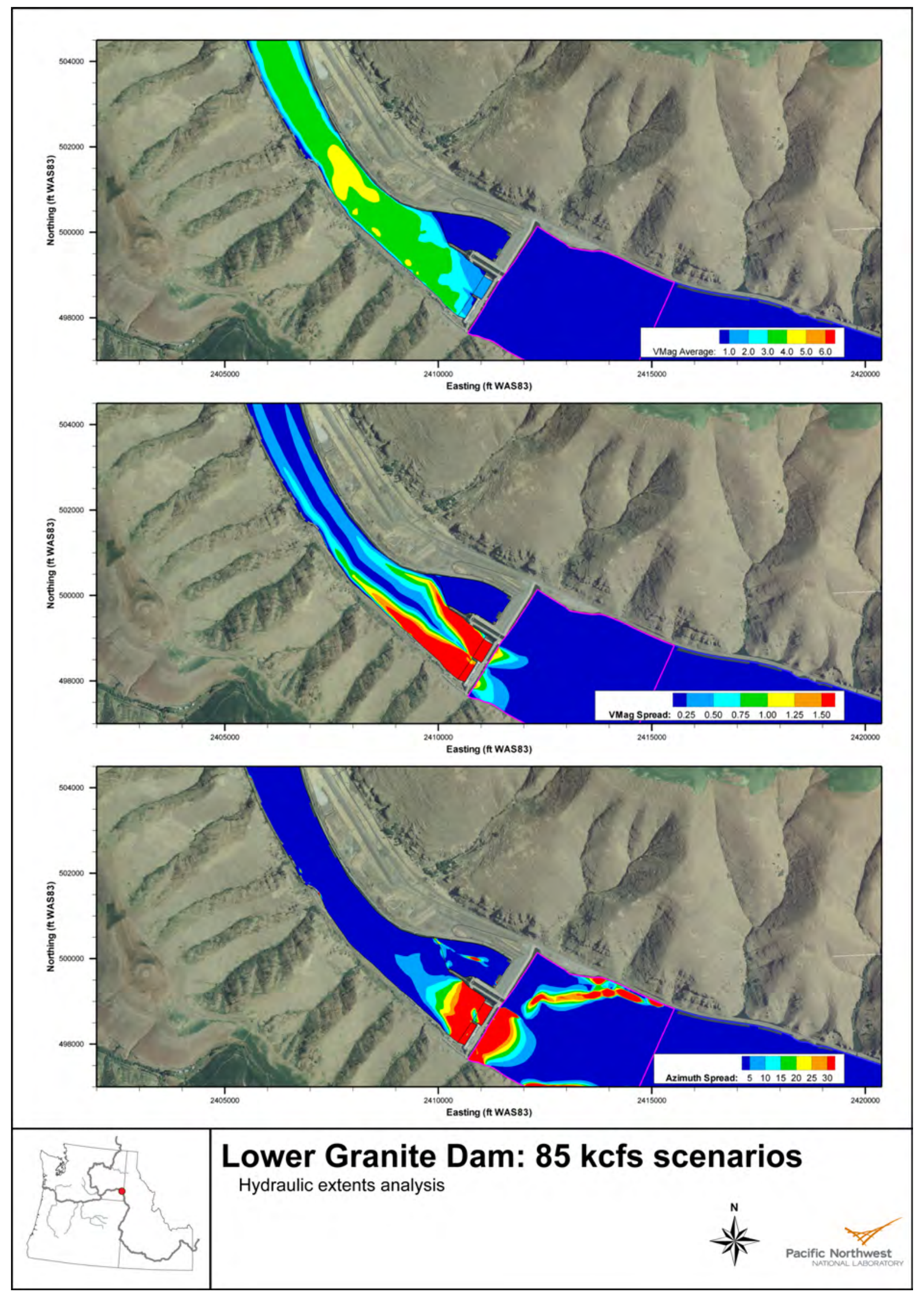

Figure 3.31. Lower Granite Project for $85 \mathrm{kcfs}$. Velocities in $\mathrm{ft} / \mathrm{s}$. 


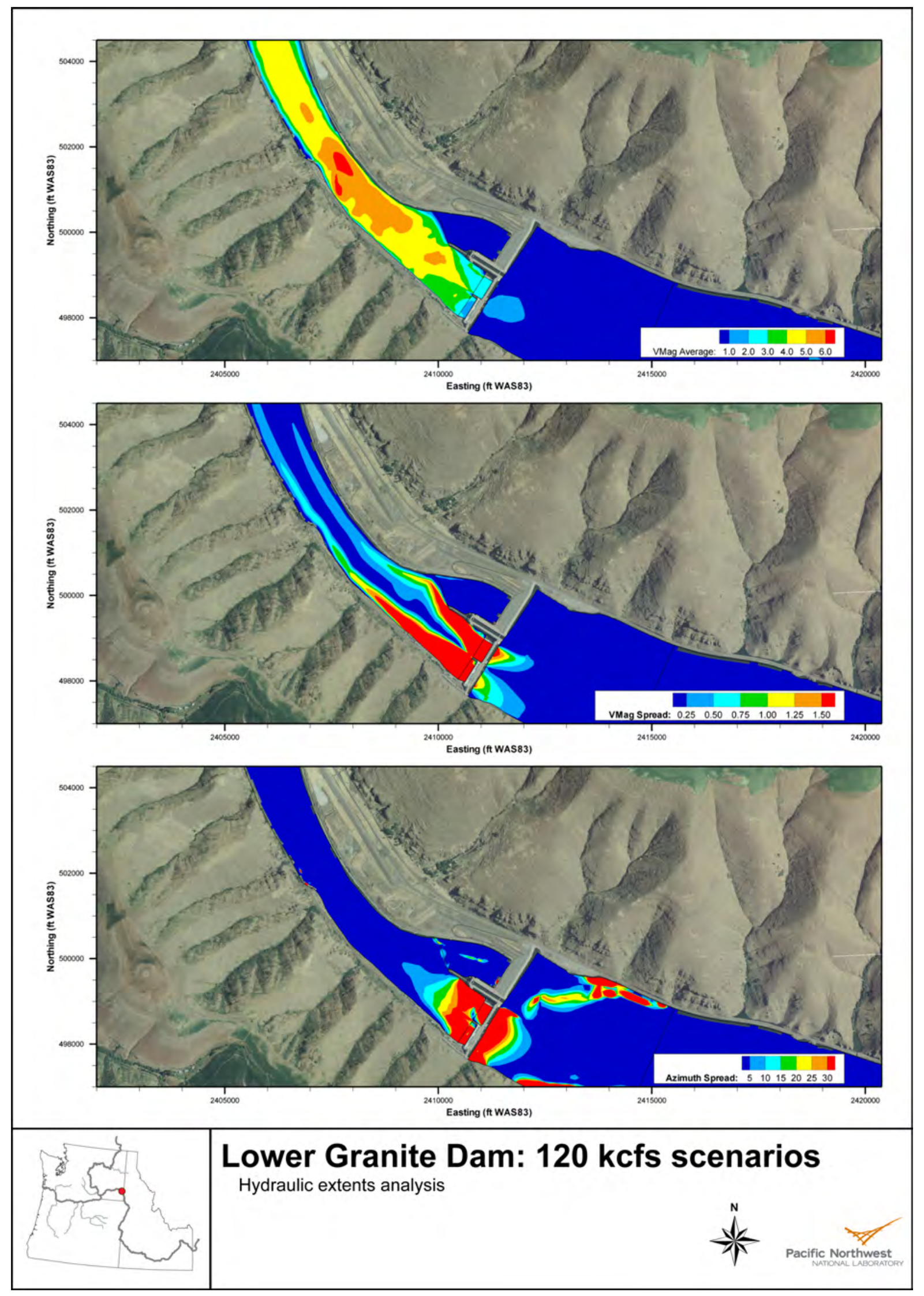

Figure 3.32. Lower Granite Project for $120 \mathrm{kcfs}$. Velocities in ft/s. 


\subsection{Hydraulic Extents}

The hydraulic extents criteria were applied to the MASS2 results for all flows at each project. Table 3.1 summarizes the distance and the Snake or Columbia River Mile of the extent location. Figures 3.33 to 3.40 show the area influenced by project operations (based on the hydraulic extents criteria) and a line showing the proposed hydraulic extent. The location of the BRZ is shown in pink on the Columbia River dams for reference.

Table 3.1. Hydraulic Extents Summary

\begin{tabular}{lrrrr}
\hline Project & \multicolumn{2}{c}{ Forebay } & \multicolumn{2}{c}{ Tailrace } \\
& Distance (ft) & River Mile & Distance (ft) & River Mile \\
Columbia River & & & & \\
\hline Bonneville & 5900 & 147.2 & 11,500 & 143.9 \\
The Dalles & 6300 & 192.9 & 5800 & 190.6 \\
John Day & 2800 & 216.2 & 7600 & 214.2 \\
McNary & 3700 & 292.7 & 7600 & 290.6 \\
\hline Snake River & & & & \\
\hline Ice Harbor & 2200 & 10.3 & 2700 & 9.4 \\
Lower Monumental & 2400 & 42.1 & 6900 & 40.3 \\
Little Goose & 2200 & 70.7 & 5100 & 69.3 \\
Lower Granite & 1100 & 107.5 & 7300 & 105.9 \\
\hline
\end{tabular}




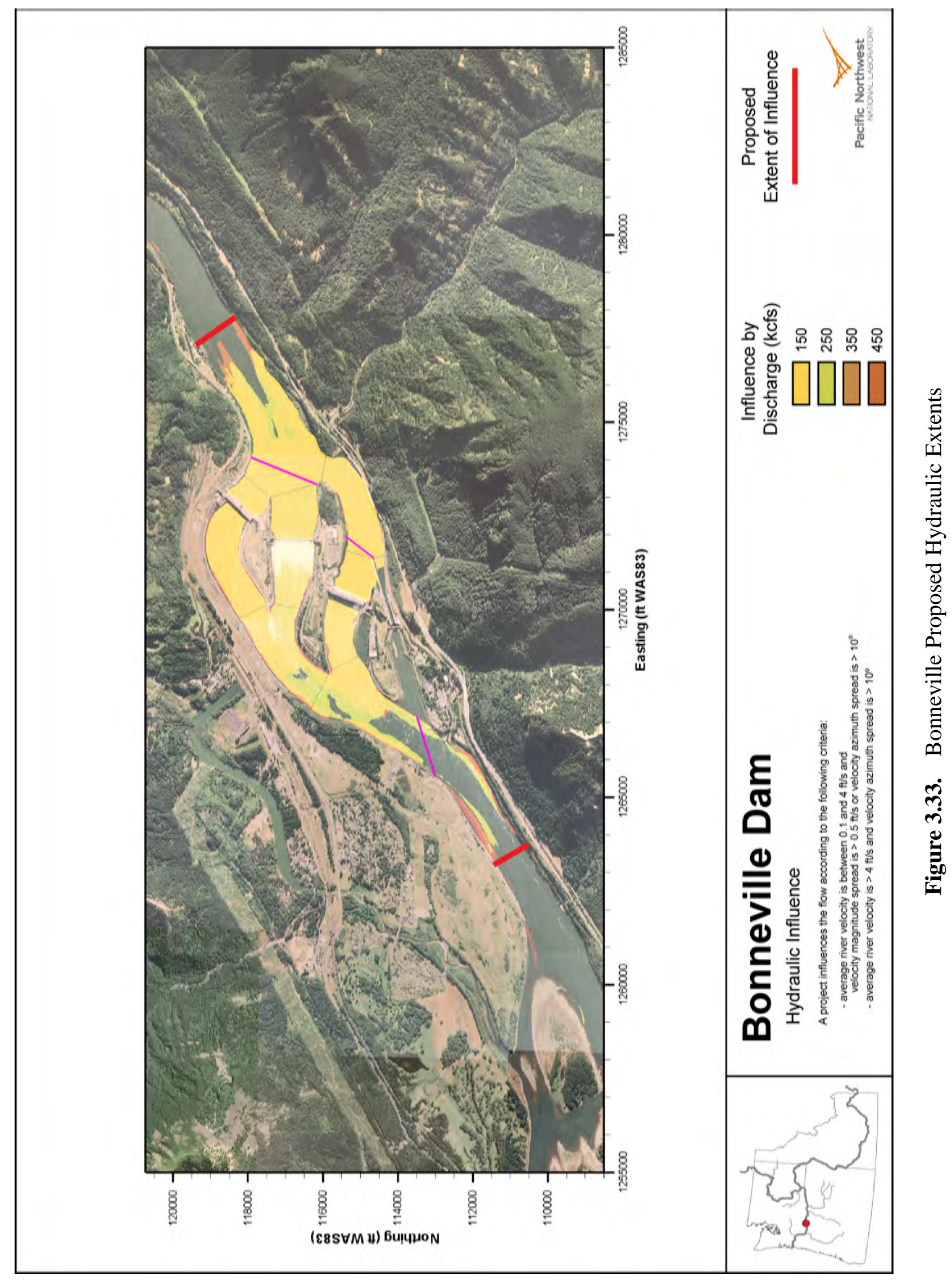




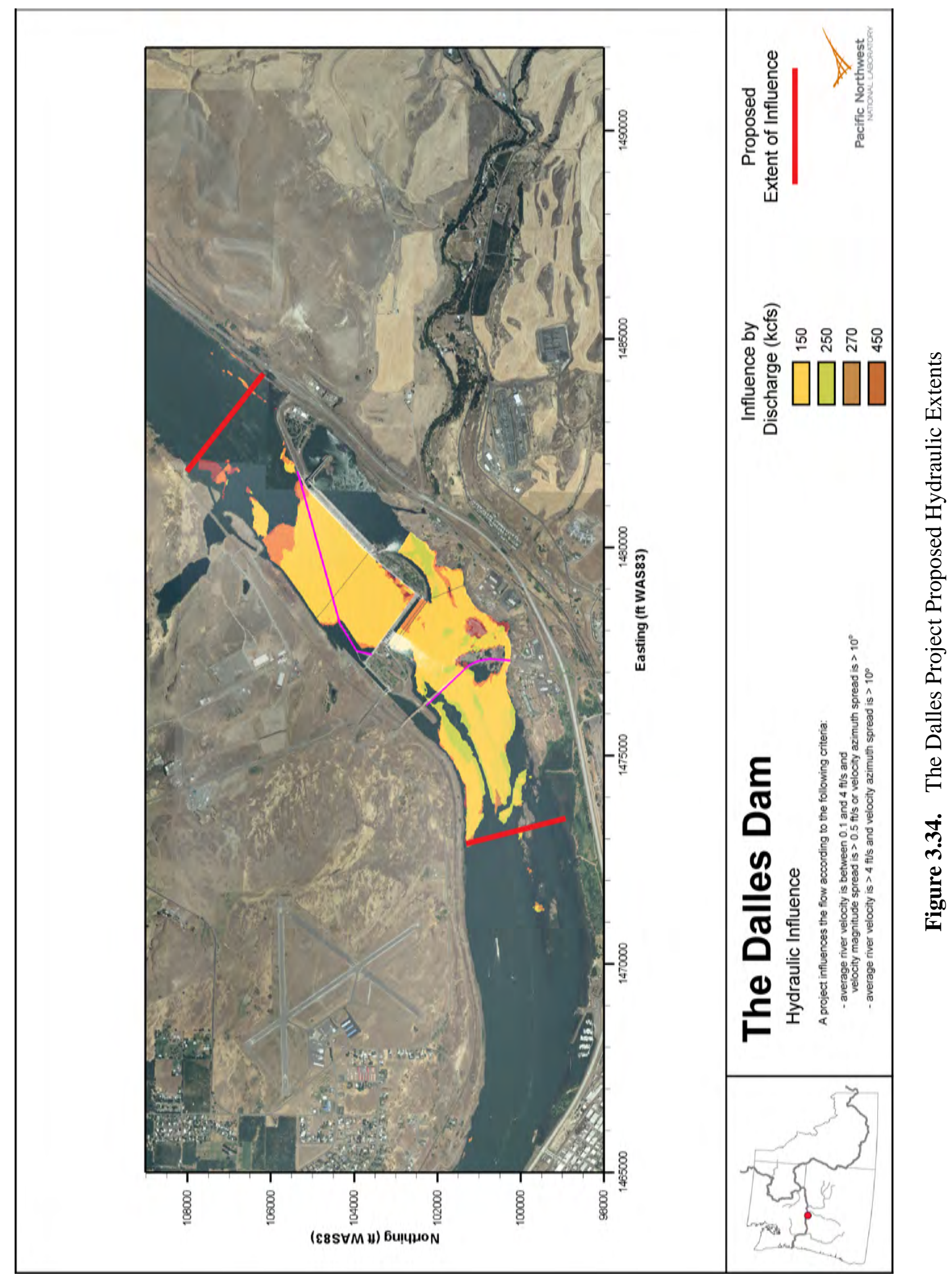




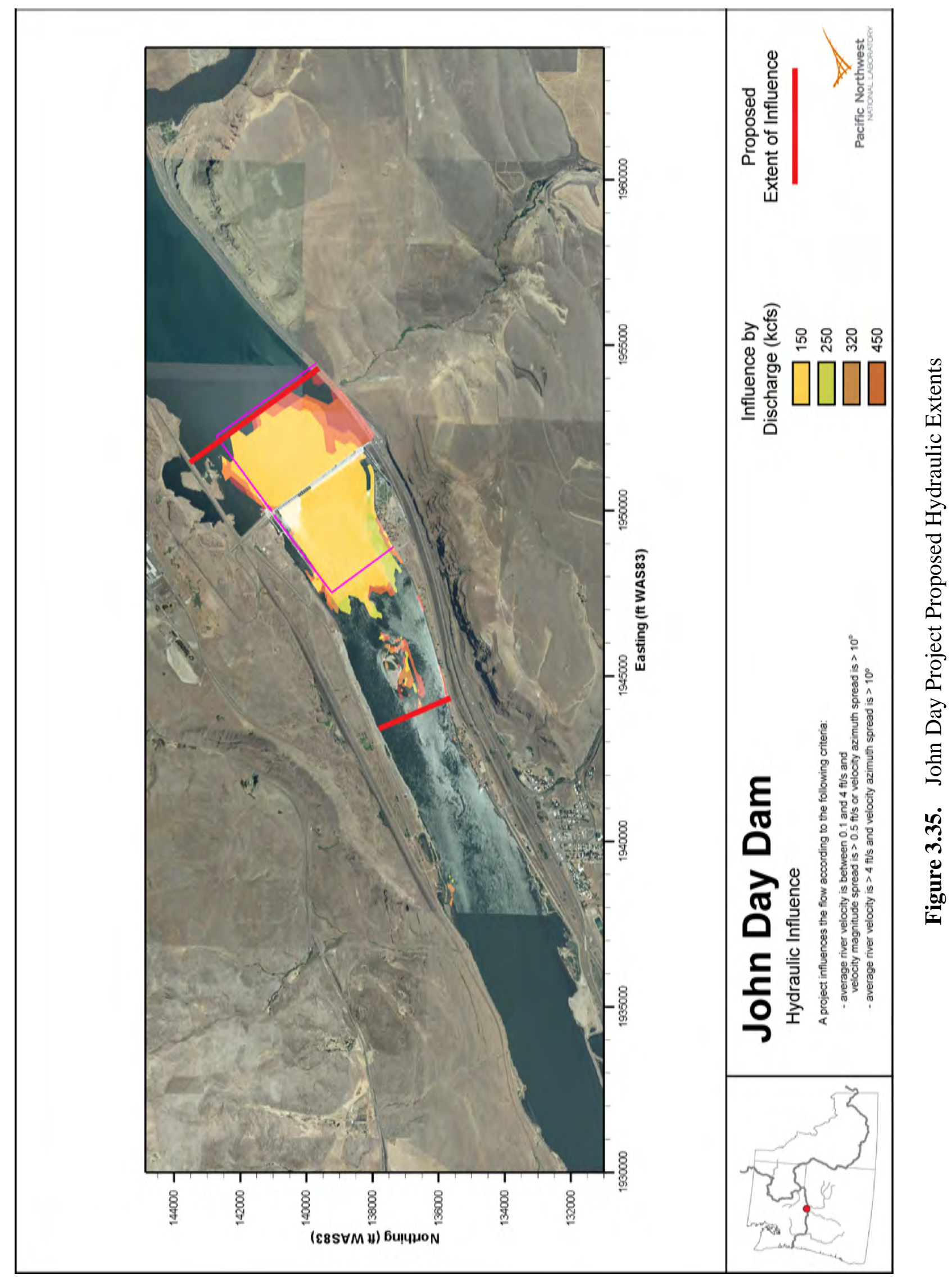




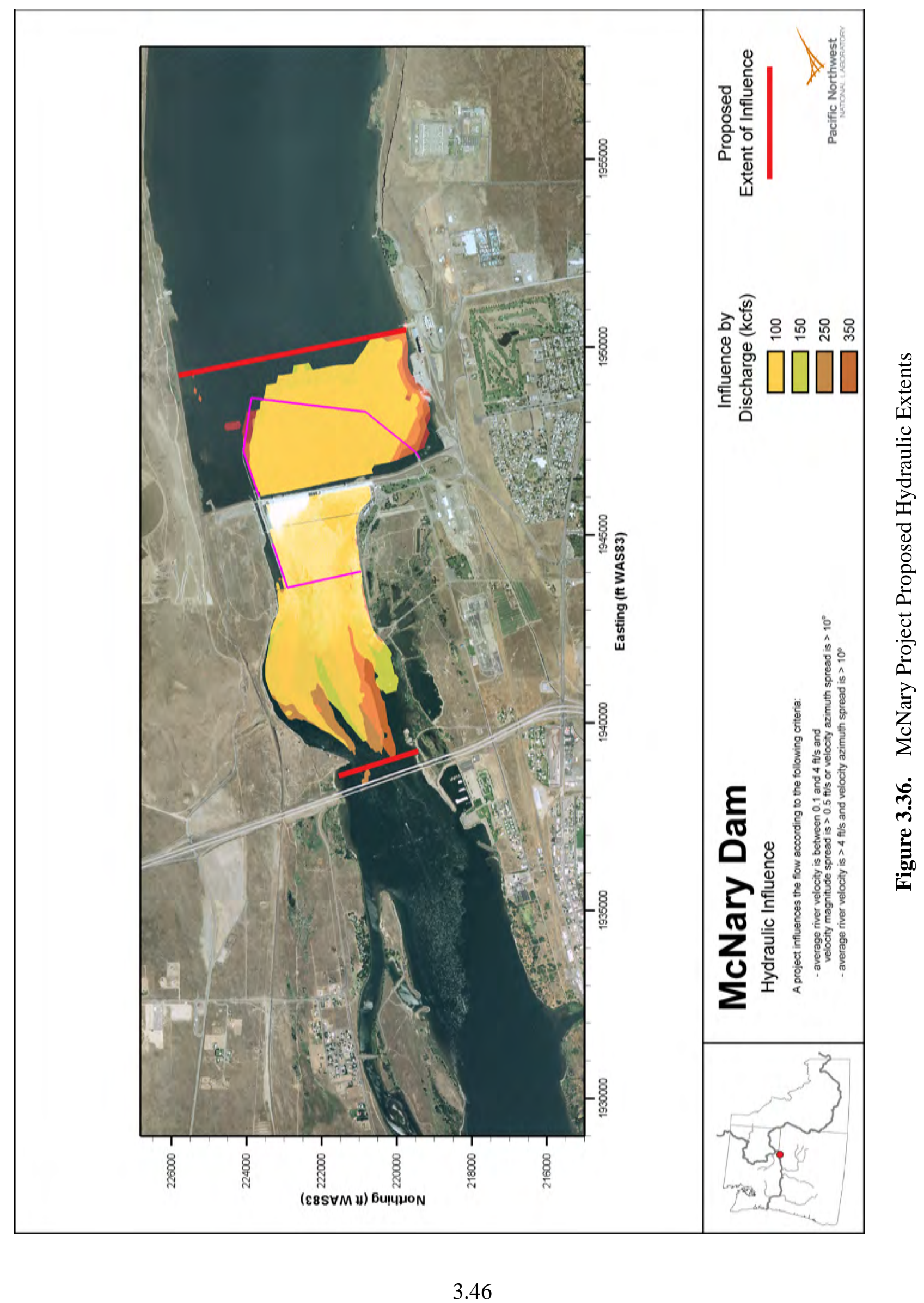




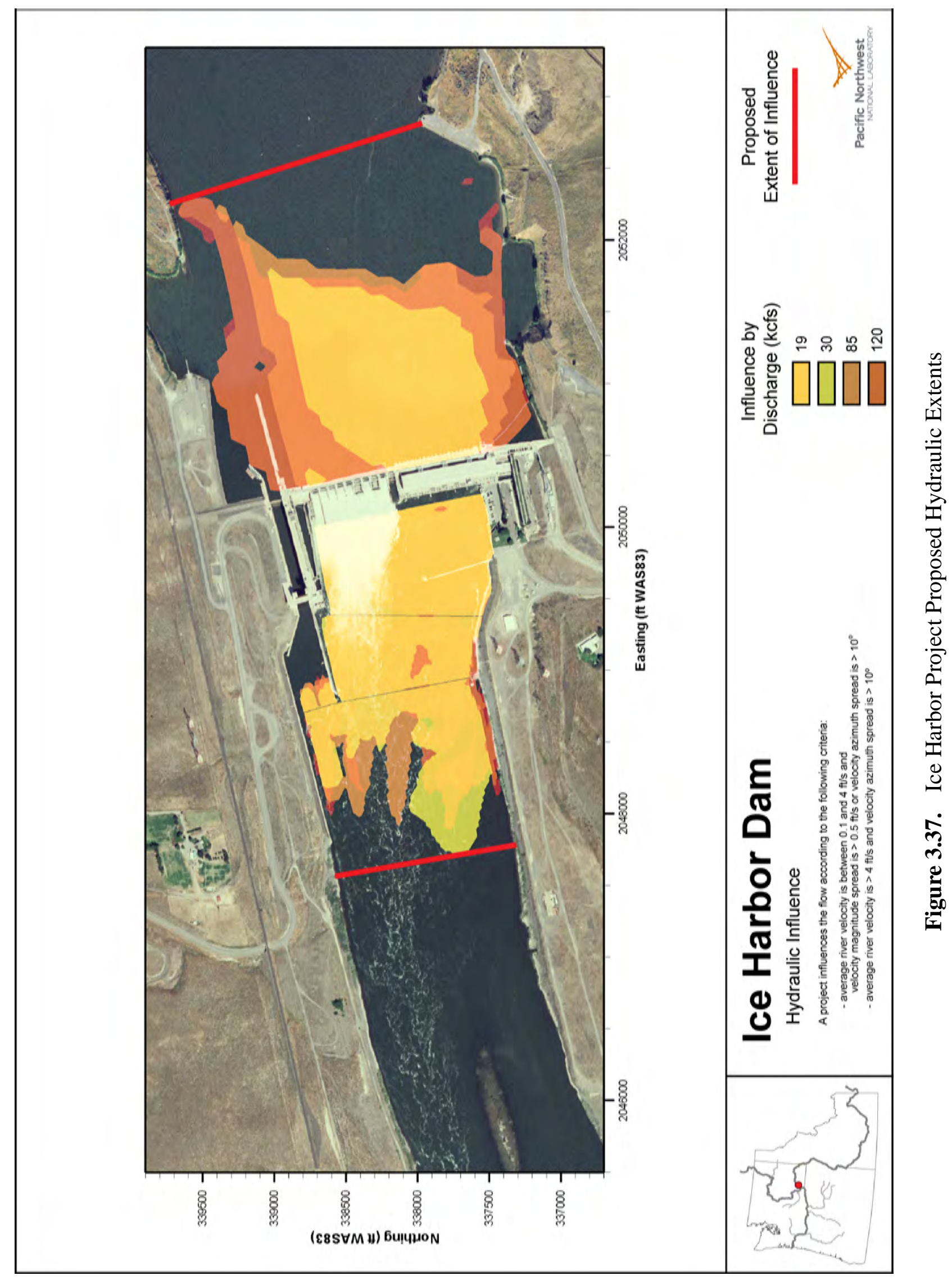




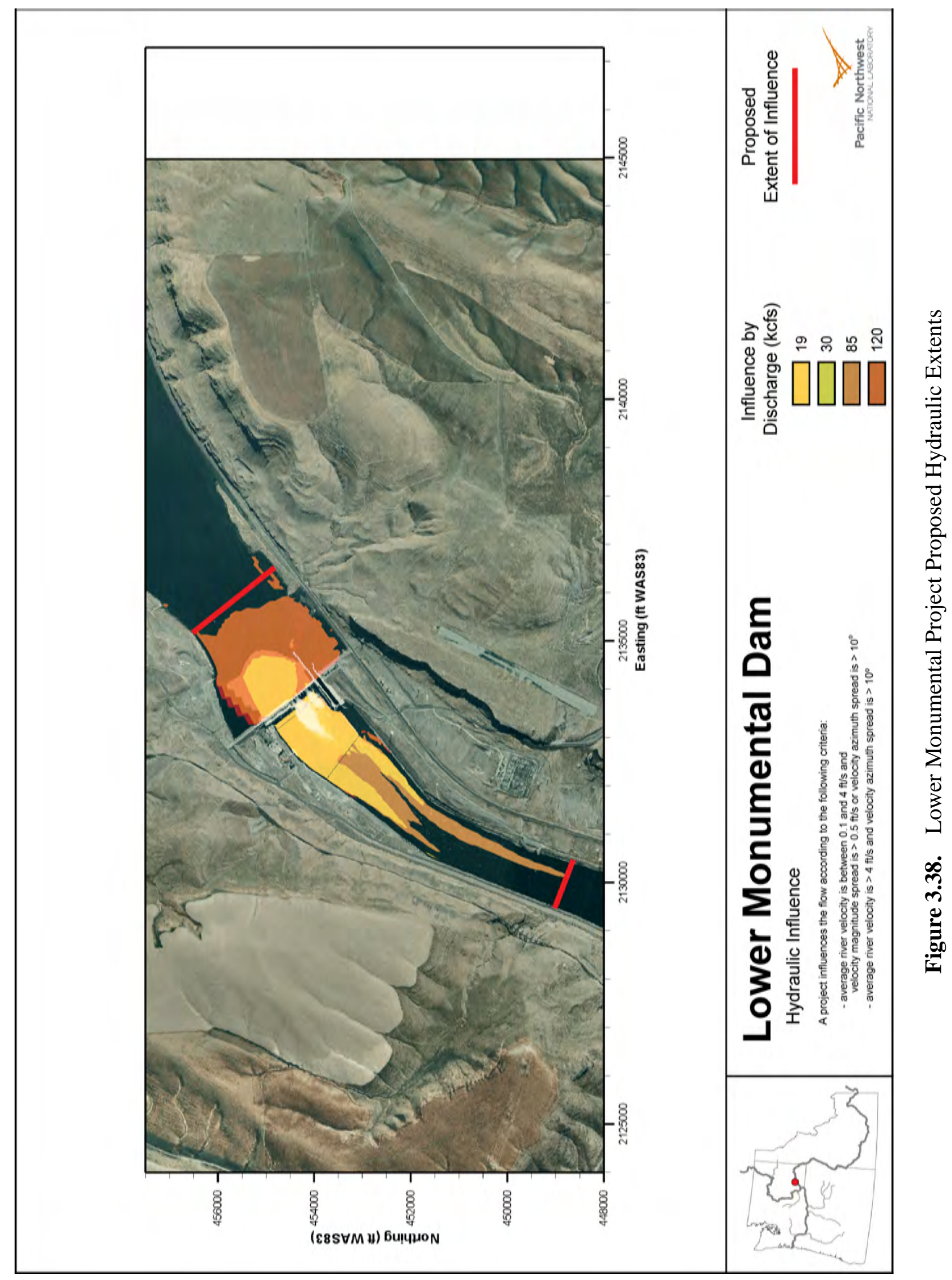




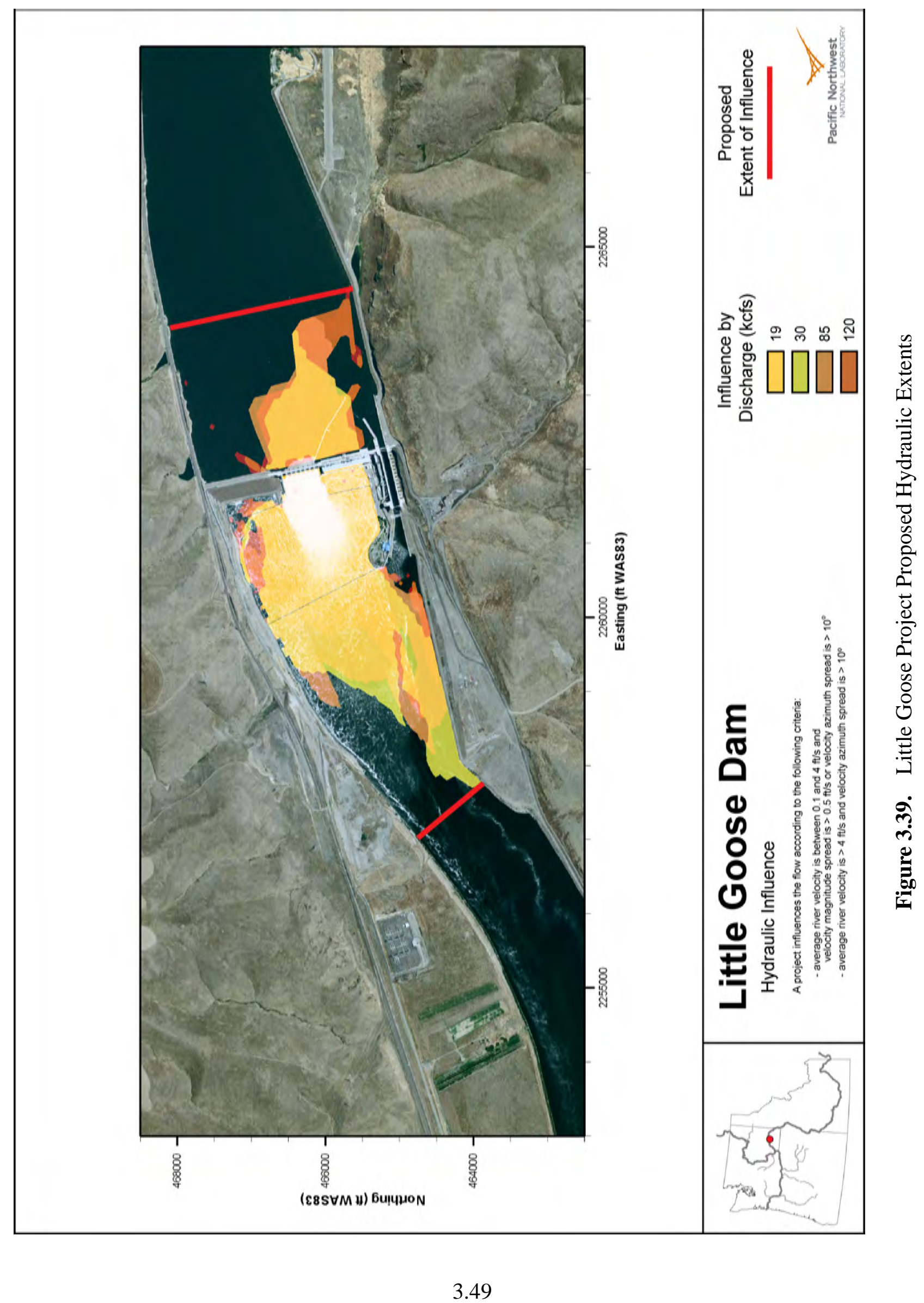




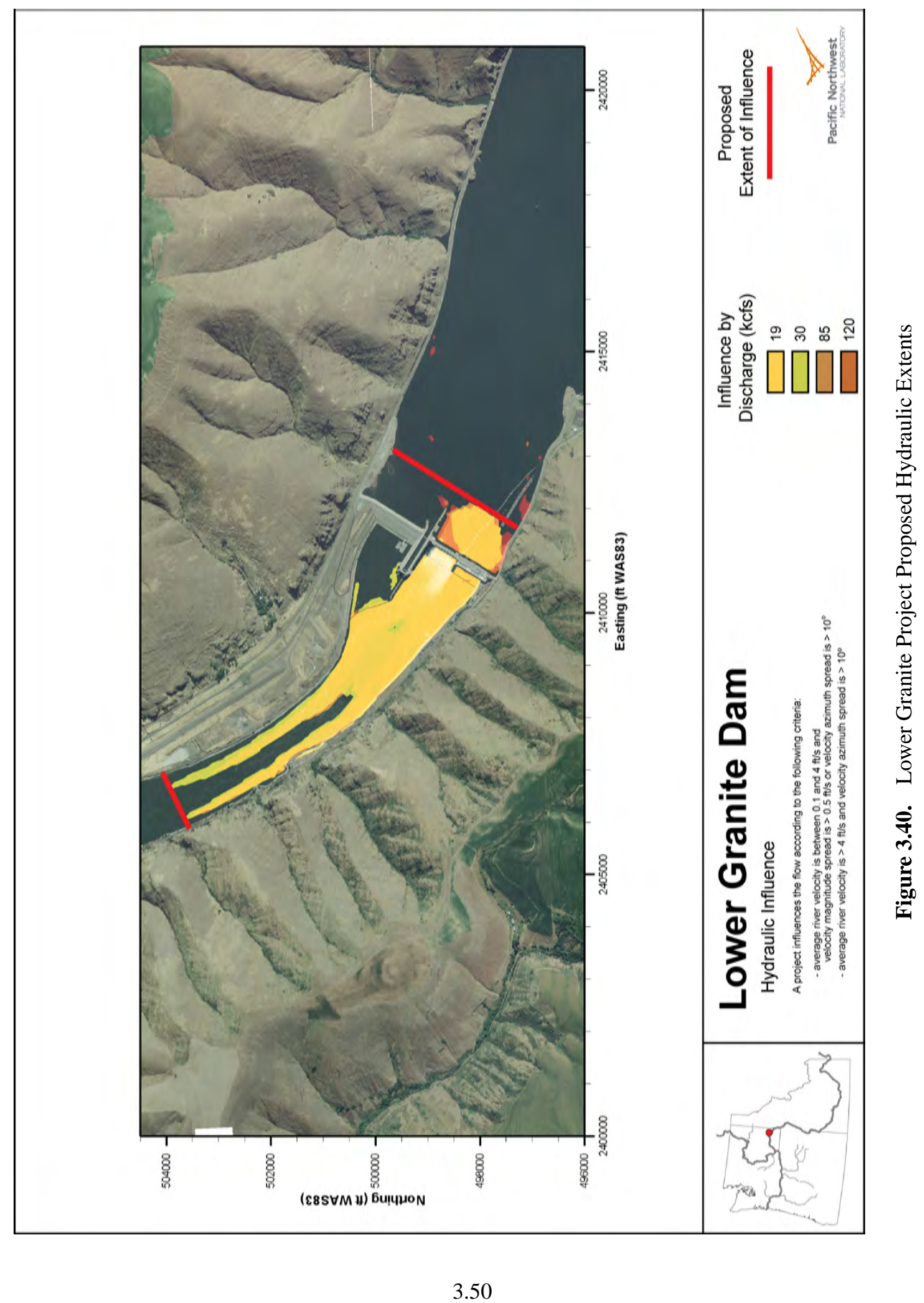




\subsection{Conclusions}

The purpose of this study was to delineate the hydraulic extents of the hydroelectric projects on the lower Columbia and lower Snake rivers in a consistent manner. Based on results from a 2D depth-averaged river model, MASS2, and criteria from USACE-CENWP, the extents were delineated for each project.

In many studies, the location of the BRZ has been used for the hydraulic extent in the lower Columbia River, and the feasibility project at John Day supported the BRZ as largely encompassing the area of project influence. For all these Columbia River projects, however, this is not consistently the case.

Although each hydroelectric project has a different physical setting, there were some common results. The downstream hydraulic extent tended to be greater than the hydraulic extent in the forebay; The Dalles is the exception. The hydraulic extent of the projects was generally larger at the mid-range flows. At higher flows, the channel geometry (in particular the channel constrictions) reduced the impact of project operations. 



\subsection{References}

Gordon J, B Evans, and E Perry. 1995. Lower Granite GIS Data Description and Collection Guidelines. PNL-10889, Pacific Northwest National Laboratory, Richland, Washington.

Hanrahan TP, MC Richmond, EV Arntzen, AM Coleman, KB Larson, WA Perkins, and JD Tagestad. 2007. Effects of Hydroelectric Dam Operations on the Restoration Potential of Snake River Fall Chinook Salmon (Oncorhynchus tshawytscha) Spawning Habitat, Final Report, October 2005-September 2007. PNNL-16944, Pacific Northwest National Laboratory, Richland WA.

Kincaid CT, RW Bryce, PW Eslinger, JM Becker, CA Brandt, AL Bunn, CR Cole, EJ Freeman, GR Guensch, DG Horton, GV Last, TB Miley, WA Perkins, WE Nichols, M Oostrom, MC Richmond, DL Strenge, and PD Thorne. 2001. "Development of a Site-Wide System Assessment Capability." Presented at the Waste Management 2001 Symposium, February 25 - March 1, 2001, sponsored by the University of Arizona, Tuscon, Arizona.

McMichael GA, WA Perkins, CJ McMurray, YJ Chien, CL Rakowski, A Coleman, MC Richmond, J Vucelick, EV Arntzen, RP Mueller, CA Duberstein, and J Lukas. 2003. Subyearling Chinook Salmon Stranding in the Hanford Reach of the Columbia River. PNWD-3308, BattellePacific Northwest Division, Richland, Washington. Prepared for Grant County Public Utility District No. 2.

Patankar S. 1980. Numerical Heat Transfer and Fluid Flow. Hemisphere, New York, New York. Perkins WA and MC Richmond. 2004a. MASS2, Modular Aquatic Simulation System in Two Dimensions, Theory and Numerical Methods. PNNL-14820-1, Pacific Northwest National Laboratory, Richland, Washington.

Perkins WA and MC Richmond. 2004b. MASS2, Modular Aquatic Simulation System in Two Dimensions, User Guide and Reference. PNNL-14820-2, Pacific Northwest National Laboratory, Richland, Washington.

Perkins WA and MC Richmond. 2004c. MASS2, Modular Aquatic Simulation System in Two Dimensions, User Guide and Reference. PNNL-14820-2, Pacific Northwest National Laboratory, Richland, Washington.

Perkins WA, MC Richmond, and G McMichael. 2004. “Two-Dimensional Modeling of TimeVarying Hydrodynamics and Juvenile Chinook Salmon Habitat in the Hanford Reach of the Columbia River.' In Critical Transitions in Water and Environmental Resources Management, Proceedings of the 2004 World Water and Environmental Resources Congress, June 27-July 1, Salt Lake City, Utah, Sehlke G, DF Hayes, and DK Stevens, eds. Reston, Virginia. ASCE.

Pointwise, Inc. 2003. Gridgen User Manual, Version 15.

Rakowski CL, WA Perkins, MC Richmond, and J Serkowski. 2008a. Determing John Day Project Tailrace and Forebay Zones Using the MASS2 Model. PNNL-SA-60840, Pacific Northwest National Laboratory, Richland, Washington. Prepared for the U.S. Army Corps of Engineers, Portland District. 
Rakowski CL, WA Perkins, MC Richmond, and JA Serkowski. 2008b. Determining John Day Project Tailrace and Forebay Zones Using the MASS2 Model. PNNL-SA-60840, Pacific Northwest National Laboratory, Richland, Washington.

Rakowski CL and MC Richmond. 2001. Dalles Tailwater Predator Study: Numerical Analysis of Tailwater Flow Conditions. PNNL-13594, Pacific Northwest National Laboratory, Richland, Washington.

Rakowski CL and MC Richmond. 2003. John Day Tailrace MASS2 Hydraulic Modeling. PNNL-14491, Pacific Northwest National Laboratory, Richland, Washington.

Richmond MC, WA Perkins, and Y Chien. 2000. Numerical Model Analysis of System-wide Dissolved Gas Abatement Alternatives. PNWD-3245, Battelle-Pacific Northwest Division, Richland, Washington. Prepared for the U.S. Army Corps of Engineers, Walla Walla District under Contract DACW68-96-D-0002.

Richmond MC, WA Perkins, and CL Rakowski. 1999a. Two-Dimensional Analysis of Flow Conditions and Sediment Mobility in the Lower Snake River for Impounded and Natural River Conditions. U.S. Department of Energy, Pacific Northwest National Laboratory, P.O. Box 999, Richland, Washington. Prepared for the U.S. Army Corps of Engineers, Walla Walla District.

Richmond MC, WA Perkins, and T Scheibe. 1999b. Summary and Model Formulation. Part 1 in Two-Dimensional Hydrodynamic, Water Quality, and Fish Exposure Modeling of the Columbia and Snake Rivers. Battelle-Pacific Northwest Division, Richland, Washington. Prepared for the U.S. Army Corps of Engineers, Walla Walla District under Contract DACW68-96-D-0002.

Richmond MC, WA Perkins, and T Scheibe. 1999c. "Two-Dimensional Simulation of Hydrodynamics, Water Quality, and Fish Exposure in the Columbia/Snake River System.” In Proceedings of WaterPower99.

Spasojevic M and F Holly, Jr. 1990. "2-D Bed Evolution in Natural Watercourses New Simulation Approach.” J. of Waterway, Port, Coastal, and Ocean Engineering 116(4):425-443.

USACE-Northwestern Division. 2008. Fish Passage Plan Corps of Engineers Project. US Army Corps of Engineers. http://www.nwd-wc.usace.army.mil/tmt/documents/fpp/.

Zhou J. 1995. "Velocity-Depth Coupling in Shallow-Water Flows.” J. of Hydraulic Engineering 121(10):717-724. 



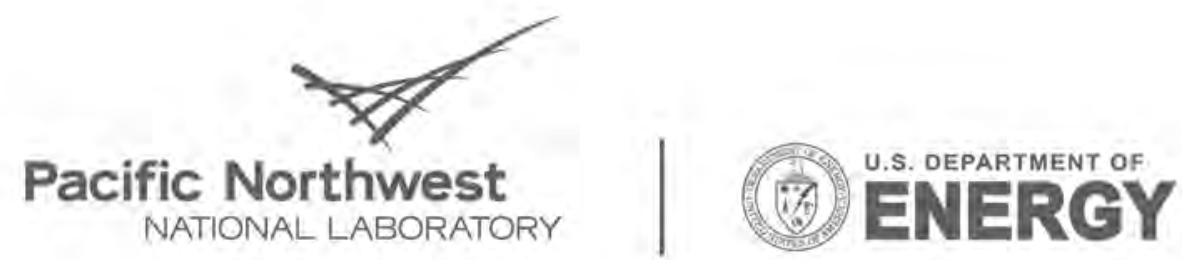

Proudly Operated by Battelle Since 1965

902 Battelle Boulevard

P.O. Box 999

Richland, WA 99352

1-888-375-PNNL (7665)

www.pnl.gov 